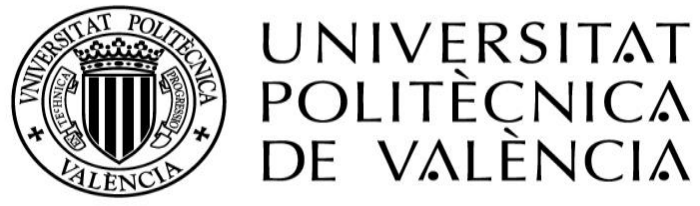

Departamento de Ciencia Animal

\title{
Application of an open circuit indirect calorimetry system for gaseous exchange measurements in small ruminant nutrition
}

This Thesis has been submitted in accordance with the requirements for the degree of Doctor at the Universitat Politècnica de València.

\section{PhD Thesis}

Patricia Fabiola Criscioni Ferreira

Thesis Supervisor

Dr. Carlos Javier Fernández Martínez

- Enero 2016 - 
Criscioni, $\mathrm{P}$.

Application of an open circuit indirect calorimetry system for gaseous exchange measurements in small ruminant nutrition

144 pages

PhD Thesis, Universitat Politècnica de València, Valencia, Spain (2016) 


\title{
THESIS EVALUATORS
}

\section{First evaluator}

Dr. Ignacio Fernández-Fígares lbánez

Consejo Superior de Investigaciones Científicas (CSIC)

\section{Second evaluator}

Dr. Fernando Emilio Bacha Baz

Nacoop, S.A.

Third evaluator

Dra. Carmen Pérez Gil

Red de Innovación en Industrias Acuícolas de la Comunidad Valenciana (RIIA-CV)

\section{THESIS COMMITTEE}

\author{
President \\ Dr. Carlos de Blas \\ Universitat Politècnica de Madrid \\ Secretary \\ Dr. Juanjo Pascual \\ Universitat Politècnica de València \\ Vocal \\ Dr. Ignacio Fernández-Fígares lbánez \\ Consejo Superior de Investigaciones Científicas (CSIC)
}



My highest gratitude to Carlos Fernández for the continuing support, for his patience in transmitting knowledge, and for being there all the time with the best attitude, the best tutor in the world! I only have good memories and infinite admiration for your work and knowledge; you will always be a great example of a scientist and of a person for me. Thanks for this opportunity.

To the boys in farm, Ion, Josevi and José Luis, this work could not have been done without your help; thanks for the good advice, for the ideas and the good will shown to me at all times, you are wonderful people and great friends.

To Carla, Paula, Mar, and all who met at the farm to carry out experiments, only you could have made the work so pleasant and fun.

To my office and department colleagues, to the ones who are still here and the ones who have left, for all shared moments, for the help and advice.

To my friends here and there, each day I feel so thankful for having you for support at all times, and I know, even though we do not get together geographically, we'll always be together; I couldn't be happier for having known you all.

To my family, thanks for the love, the support, the understanding, and for putting up with the long distance in hard times. You were and will always be my greatest blessing and the motor in my life.

To finish, I want to thank everybody who in one way or another have helped me all this time and made possible that my stay here would be pleasant. 



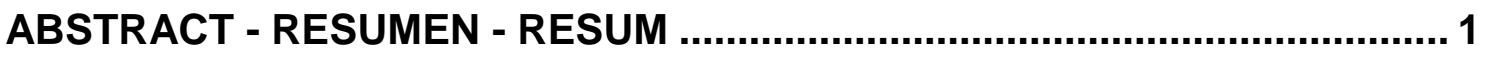

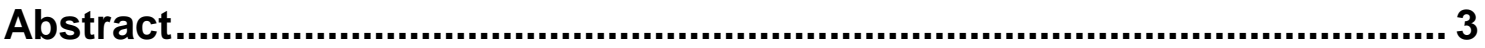

Resumen

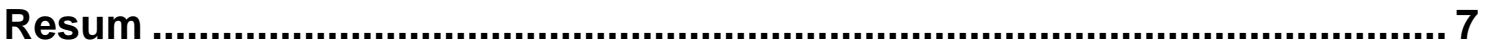

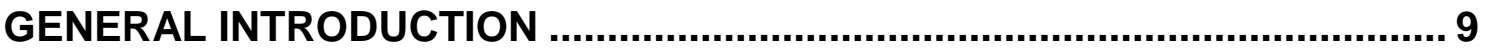

I. Food and energy metabolism................................................................... 11

II. Metabolic rate and energy metabolism determination techniques ........ 11

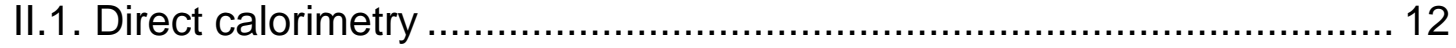

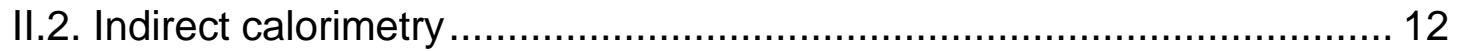

II.2.1. Carbon and Nitrogen balance ................................................. 13

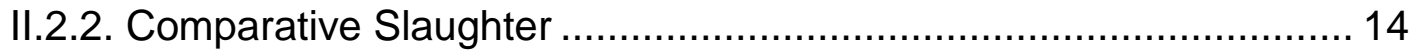

II.2.3. Respiration chamber, head hood and face mask.......................... 14

II.2.4. Comparison among methods .................................................... 17

III. Energy Requirements ........................................................................... 17

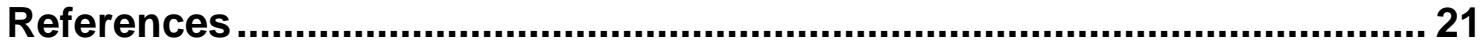

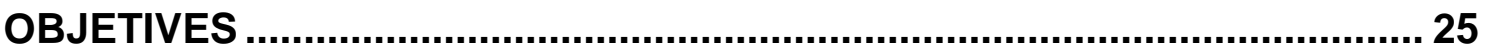

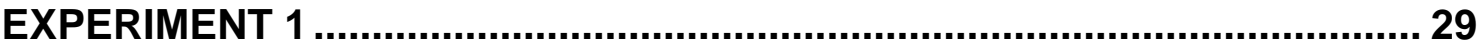

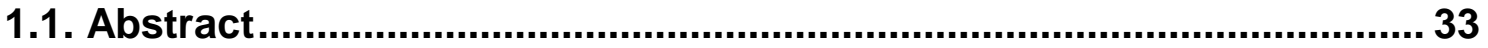

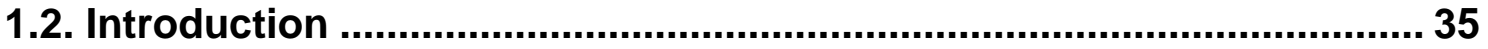

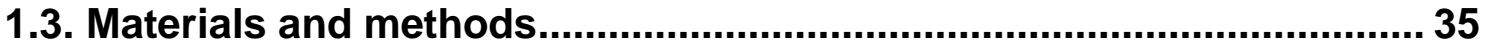

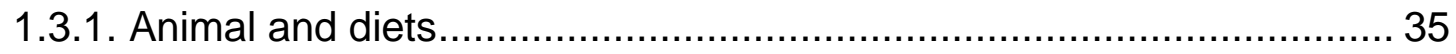

1.3.2. Experimental Schedule and Measurements..................................... 36

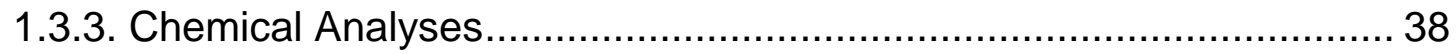

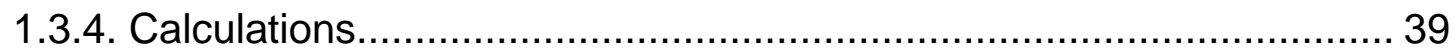

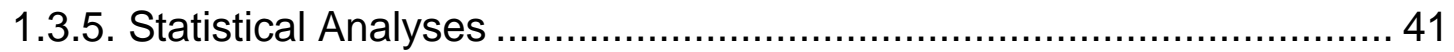

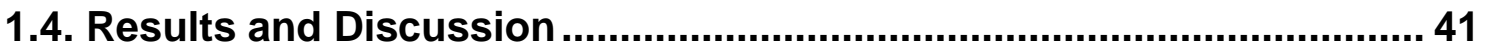

1.4.1. Feed Intake, Digestibility and Rumen Fermentation........................... 41

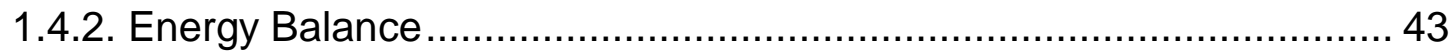

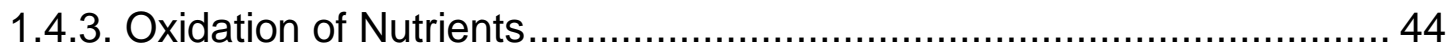

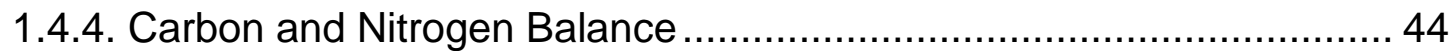

1.4.5. Milk Production, Fatty Acid and Metabolites .................................... 45

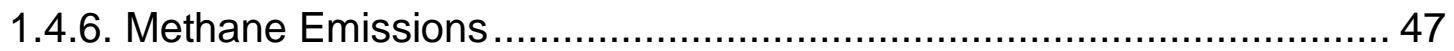

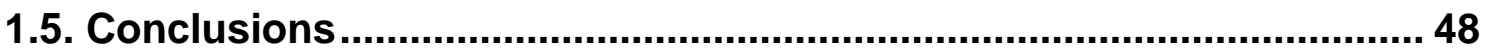

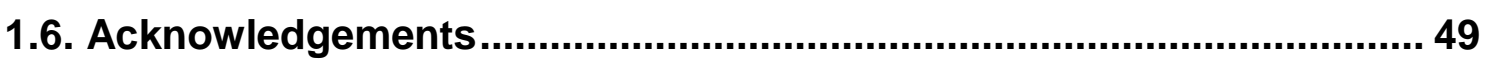

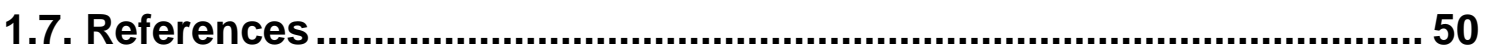


EXPERIMENT 2

2.1. Abstract

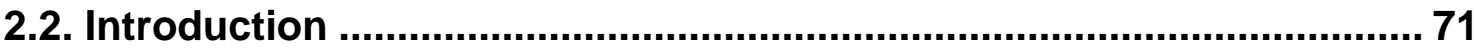

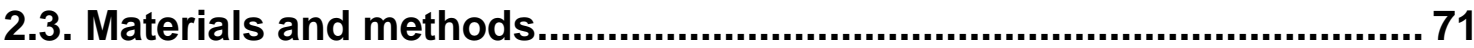

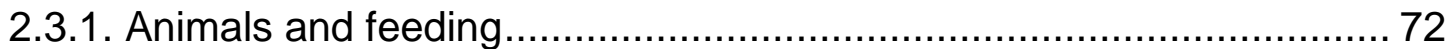

2.3.2. Experimental schedule and measurements ..................................... 72

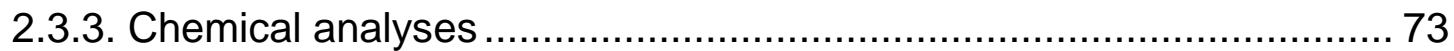

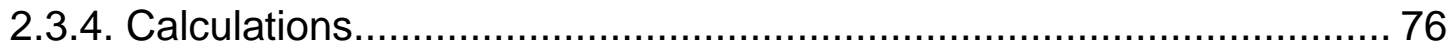

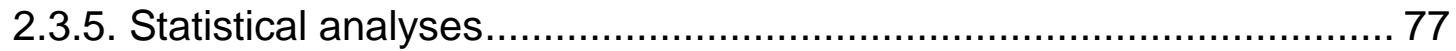

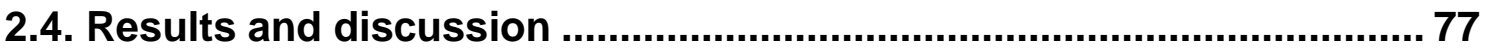

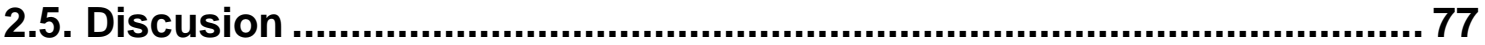

2.5.1. Intake, apparent digestibility and rumen parameters........................ 79

2.5.2. Energy balance and oxidation of nutrients ...................................... 79

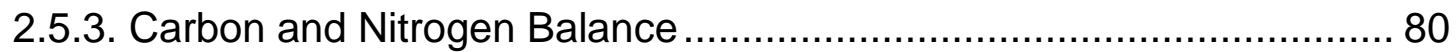

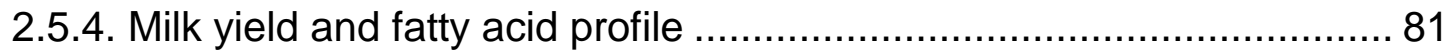

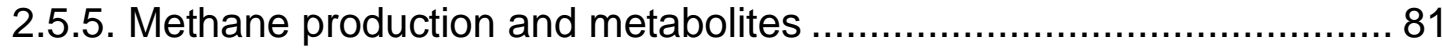

2.6. Conclusions

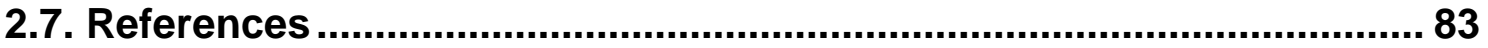

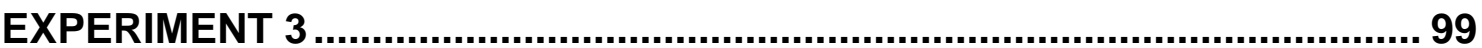

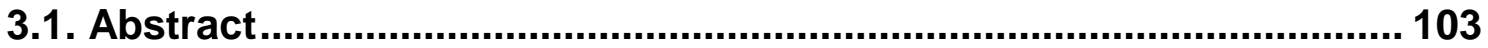

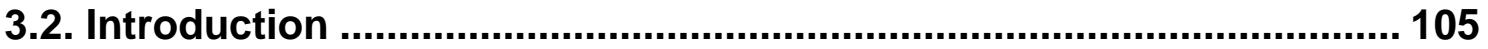

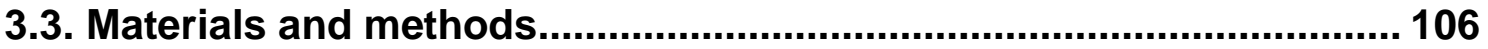

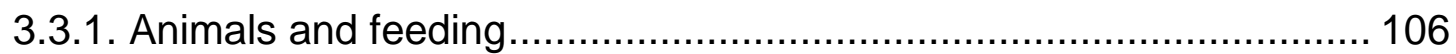

3.3.2. Experimental Schedule and Measurements................................... 106

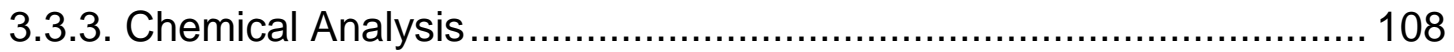

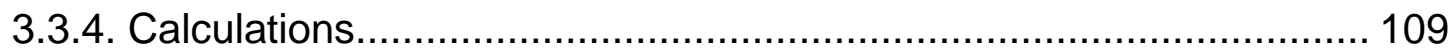

3.3.5. Heat Production Partition ........................................................ 110

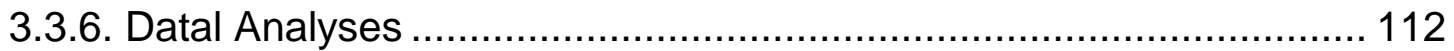

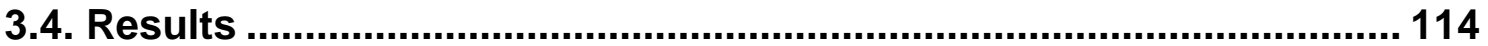

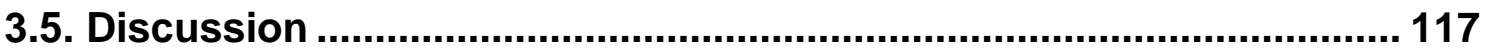

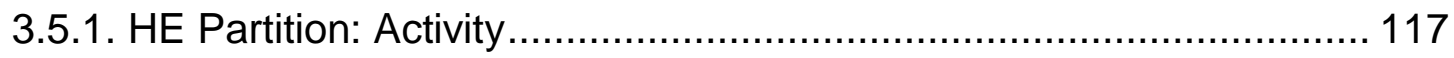

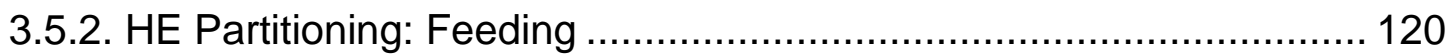

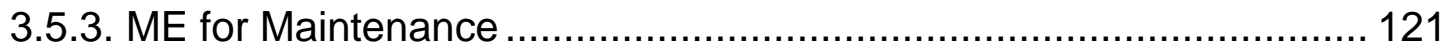

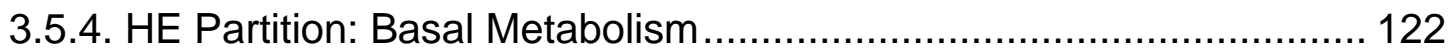

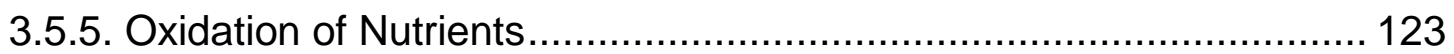


3.5.6. Nitrogen Balance and Rumen Parameters.................................... 124

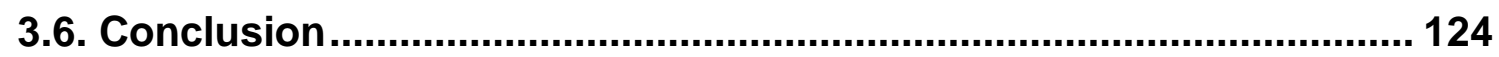

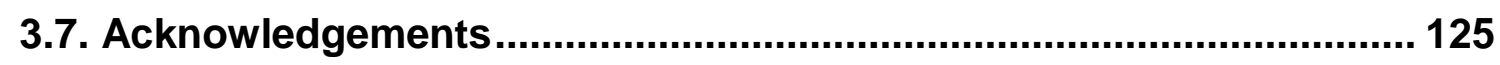

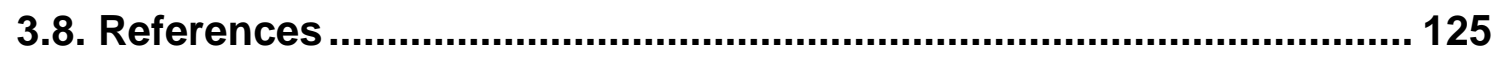

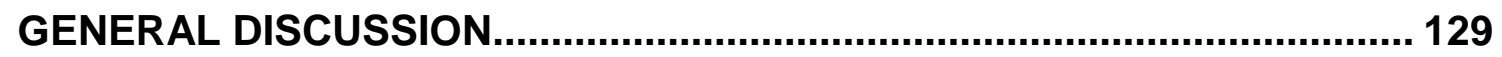

Experiments in this work point to different applications for calorimetry and will be discussed independently. .................................................... 132

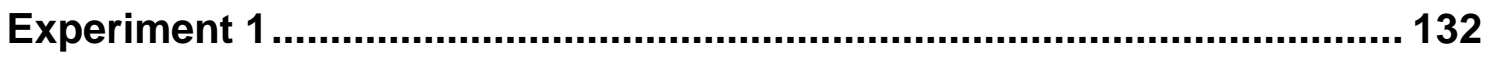

Experiment 2

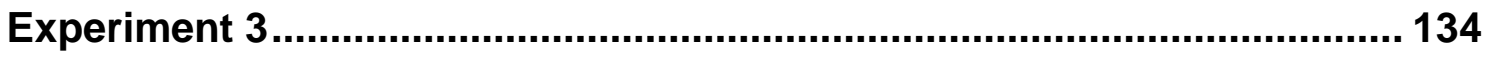

CONCLUSIONS

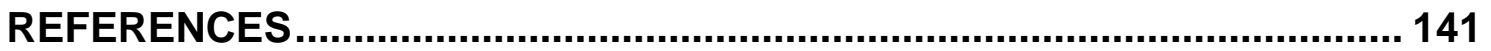



Table 1.1. Ingredients and chemical composition of the mixed diets diets. 55

Table 1.2. Body weight, intake, and apparent digestibility coefficients of Murciano-Granadina goats $(n=10)$ during late lactation according to the type of diet.

Table 1.3. $\mathrm{pH}$, ammonia-N $\left(\mathrm{NH}_{3}-\mathrm{N}\right)$, and VFA of Murciano-Granadina goats $(\mathrm{n}=$ 10) during late lactation according to the type of diet.

Table 1.4. Daily energy partitioning ( $\mathrm{kJ} / \mathrm{kg}$ of $\left.\mathrm{BW}^{0.75}\right)$ of Murciano-Granadina goats $(n=10)$ during late lactation according to the type of diet. 58

Table 1.5. Heat production $\left(\mathrm{kJ} / \mathrm{kg}\right.$ of $\mathrm{BW}^{0.75}$ ) from oxidation and fermentation; daily oxidation $\left(\mathrm{kJ} / \mathrm{kg}\right.$ of $\left.\mathrm{BW}^{0.75}\right)$ of protein, carbohydrate, and fat; and their contribution to the heat production from oxidation substrates (\%) of MurcianoGranadina goats $(n=10)$ during late lactation according to the type of diet.... 59 Table 1.6. Carbon and nitrogen balance $\left(\mathrm{g} / \mathrm{kg}\right.$ of $\left.\mathrm{BW}^{0.75}\right)$ of Murciano-Granadina goats $(n=10)$ during late lactation according to the type of diet. 60

Table 1.7. Daily milk production, composition and metabolites of MurcianoGranadina goats $(n=10)$ during late lactation according to the type of diet.... 61 Table 1.8. Fatty acid composition ( $\mathrm{g} / 100 \mathrm{~g}$ of identified fatty acids) of milk fat for Murciano-Granadina goats $(n=10)$ during late lactation according to the type of diet

Table 1.9. Methane emission of Murciano-Granadina goats $(n=10)$ during late lactation according to the type of diet.

Table 2.1. Ingredients and chemical composition of the diets (dry matter [DM] basis: $\mathrm{g} / \mathrm{kg} \mathrm{DM})$.

Table 2.3. $\mathrm{pH}$, ammonia- $\mathrm{N}\left(\mathrm{NH}_{3}-\mathrm{N}\right)$, and VFA of Murciano-Granadina goats $(\mathrm{n}=$ 10) during late lactation according to the type of diet.

Table 2.4. Daily energy partitioning ( $\mathrm{kJ} / \mathrm{kg}$ of $\left.\mathrm{BW}^{0.75}\right)$ of Murciano-Granadina goats $(n=10)$ during late lactation according to the type of diet. 92

Table 2.5. Heat production ( $\mathrm{kJ} / \mathrm{kg}$ of $\mathrm{BW}^{0.75}$ ) from oxidation and fermentation; daily oxidation $\left(\mathrm{kJ} / \mathrm{kg}\right.$ of $\mathrm{BW}^{0.75}$ ) of protein, carbohydrate, and fat; and their contribution to the heat production from oxidation substrates of MurcianoGranadina goats $(n=10)$ during late lactation.

Table 2.6. Carbon and nitrogen balance $\left(\mathrm{g} / \mathrm{kg}\right.$ of BW $\left.{ }^{0.75}\right)$ of Murciano-

Granadina goats $(n=10)$ during late lactation according to the type of diet.... 94 
Table 2.7. Daily milk production and chemical composition $(\mathrm{g} / \mathrm{kg})$ of MurcianoGranadina goats $(n=10)$ during late lactation according to the type of diet..... 95 Table 2.8. Fatty acid composition ( $\mathrm{g} / 100 \mathrm{~g}$ of identified fatty acids) of milk fat of Murciano-Granadina goats $(n=10)$ during late lactation according to the type of diet. 96

Table 2.9. Methane emission of Murciano-Granadina goats $(n=10)$ during late lactation according to the type of diet. 97

Table 2.10. Metabolites in milk, urine and plasma of Murciano-Granadina goats $(n=10)$ during late lactation according to the type of diet. 98

Figure 1. Example of heat production (HE) partitioning and their components: fasting heat production (FHP), basal metabolism ( $\mathrm{HeE})$, heat associated with voluntary activity $(\mathrm{HjE})$, heat of digestion $(\mathrm{HdE})$, heat of feeding during 3 hours $(\mathrm{HdEe})$, heat after 3 hours of feeding to next intake $(\mathrm{HdEdm}) . \mathrm{FHP}=\mathrm{HeE}$ $+\mathrm{HjE} ; \mathrm{HdE}=\mathrm{HdEe}+\mathrm{HdEdm}$. 113

Table 3.1. Definition of the areas and temporal series used in the numerical integration.

Table 3.2. Dry matter intake $(\mathrm{g} / \mathrm{d})$ and energy balance $\left(\mathrm{kJ} / \mathrm{kg}\right.$ of $\left.\mathrm{BW}^{0.75}\right)$ in two sheep breeds.

Table 3.3 HE partitioning (kJ/kg of $\mathrm{BW}^{0.75}$ ) and HE partitioning per MEI (\%) in two sheep breeds.

Table 3.4. Energy $\left(\mathrm{kJ} / \mathrm{kg}\right.$ of $\left.\mathrm{BW}^{0.75}\right)$ associated with the oxidation of nutrients and their percentage over $\mathrm{HxE}$ in two sheep breeds.

Table 3.5. Nitrogen balance $\left(\mathrm{g} / \mathrm{kg}\right.$ of $\left.\mathrm{BW}^{0.75}\right)$ in two sheep breeds

Table 3.6. $\mathrm{pH}$, ammonia $\mathrm{N}$ and volatile fatty acids (VFA) in two sheep breeds.

Figure 2. Example of oxidation of nutrients: heat production due to oxidation of nutrients $(\mathrm{HxE})$, oxidation of protein (OXP), oxidation of carbohydrates $(\mathrm{OXCHO})$, and oxidation of fat $(\mathrm{OXF})$. 

A Alfalfa diet
ADF Acid detergent fiber
BHBA B-hydroxybutyrate
BW Body weight
CB Carbon balance
$\mathrm{CH}_{4} \quad$ Methane
C Carbon
$\mathrm{C}_{\text {feces }} \quad$ Carbon in feces
$\mathrm{C}_{\text {intake }} \quad$ Carbon intake
$\mathrm{C}_{\text {milk }} \quad$ Carbon in milk
$\mathrm{C}_{\text {urine }} \quad$ Carbon in urine
$\mathrm{CO}_{2} \quad$ Carbon dioxide
$\mathrm{CO}_{2 x} \quad$ Carbon dioxide production from oxidation
CLA Conjugated linoleic acid
CP Crude protein
DEI Digestible energy intake
DM Dry matter
DMI Dry matter intake
EE Ether extract
$E_{\text {feces }} \quad$ Energy retained in feces
$E_{\text {methane }} \quad$ Energy retained in methane
$E_{\text {milk }} \quad$ Energy retained in milk
Eurine Energy retained in urine
FA Fat acid
FHP Fasting heat production
GE Gross energy
GEI Gross energy intake
$\mathrm{H}_{2} \quad$ Dihydrogen
$\mathrm{HcE} \quad$ Heat for thermal regulation
$\mathrm{HdE} \quad$ Heat of digestion
HdEdm Heat of digestion and metabolism
$\mathrm{HdEe} \quad$ Heat energy of eating
$\mathrm{HdE}_{\mathrm{e}} \quad$ Heat increment post ingestion 
HE Heat energy/production

HeE Basal metabolism

HfE Heat of fermentation

HiE Heat increment

$\mathrm{HjE} \quad$ Heat associated with voluntary activity

HP Heat production

$\mathrm{HP}_{\mathrm{CN}} \quad$ Heat production determined by $\mathrm{CN}$ method

$\mathrm{HPf} \quad$ Heat production of fermentation

HPx Heat production from oxidation of nutrients

$\mathrm{H}_{3} \mathrm{PO}_{4} \quad$ Phosphoric acid

$\mathrm{HrE} \quad$ Heat of product formation

HS High starch diet

$\mathrm{H}_{2} \mathrm{SO}_{4} \quad$ Sulfuric acid

HwE Heat of synthesis and excretion of waste products

HxE Heat energy from oxidation

$\mathrm{Kg} \quad$ Kilogram

$k_{l} \quad$ Efficiency of use of ME for milk production

M Maralfalfa diet

ME Metabolizable energy

MEI Metabolizable energy intake

MEm Metabolic energy for maintenance

MEr Metabolic energy used for tissue gain

$\mathrm{N} \quad$ Nitrogen

$\mathrm{N}_{\text {feces }} \quad$ Nitrogen in feces

$\mathrm{N}_{\text {intake }} \quad$ Nitrogen intake

$\mathrm{N}_{\text {milk }} \quad$ Nitrogen in milk

$\mathrm{N}_{\text {urine }} \quad$ Nitrogen in urine

NB Nitrogen balance

NDF Neutral detergent fiber

NEFA Non esterified fatty acids

NFC Non fibrous carbohydrates

$\mathrm{NH}_{3} \mathrm{~N}$ Ammonia nitrogen

$\mathrm{NE}_{\mathrm{L}} \quad$ Net energy for lactation 
Nur Urine nitrogen

O Oat grain diet

$\mathrm{O}_{2} \quad$ Oxygen

OM Organic matter

OMI Organic matter intake

$\mathrm{OXCHO}$ Oxidation of carbohydrates

OXF Oxidation of fat

OXP Oxidation of protein

RB Rice Bran diet

RE Retained energy

$\mathrm{RE}_{\text {body }} \quad$ Retained energy in body tissues

$\mathrm{RE}_{\text {fat }} \quad$ Retained energy as fat

$\mathrm{RE}_{\text {milk }} \quad$ Retained energy as milk

$\mathrm{RE}_{\text {protein }} \quad$ Retained energy as protein

$\mathrm{RQ} \quad$ Respiratory quotient

RQnpx Non protein respiratory quotient from oxidation of nutrients

SEM Standard error of the mean

TE Tissue energy

VFA Volatile fatty acids

Ym Methane energy/gross energy intake 

ABSTRACT - RESUMEN - RESUM 



\section{Abstract}

The main objective of this Thesis was to study the energy metabolism in small ruminants under different nutrition sceneries. As methodology we utilized indirect calorimetry instead of direct calorimetry or feeding trials. Within indirect calorimetry we worked with a portable open circuit gas exchange system with a head hood. This open circuit respiration system permitted completed the whole energy balance and evaluate the efficiency of utilization of the energy of the diet for different physiological circumstances as milk production in dairy goats or maintenance in sheep. Besides, we could quantify in each trial some of the wastes related to environmental pollution as $\mathrm{CH}_{4}$ emissions and excretion of nitrogen in feces and urine.

In this thesis three experiments were designed, two in dairy goats and other in sheep as we described below.

In the first experiment, digestibility, energy balance, carbon and nitrogen balance, milk performance, rumen parameters and milk fatty acids and metabolites were obtained. Metabolic cages and open circuit indirect calorimetry system were the methods applied. Treatments consist in two mixed diets with alfalfa as forage. Within the concentrate, oat grain was replaced with rice bran. No significant differences were found for metabolizable energy intake (MEI), $1254 \mathrm{~kJ} / \mathrm{kg}$ of $\mathrm{BW}^{0.75}$ on average, and heat production (HP); $640 \mathrm{~kJ} / \mathrm{kg}$ of $\mathrm{BW}^{0.75}$ on average. No differences were obtained for milk production $(2.2 \mathrm{~kg} / \mathrm{d}$ on average) and milk fat was greater in the rice bran diet (6.9\% vs. 5.3\% for rice bran and oat diets, respectively). Energy balance was positive and milk metabolites correlated these found. Regards to $\mathrm{CH}_{4}$ emissions, determined in vivo by gas exchange indirect calorimetry, goats fed the rice bran significantly reduced methane production $(23.2 \mathrm{~g} / \mathrm{d}$ vs $30.1 \mathrm{~g} / \mathrm{d})$.

In the second experiment, we also used two types of diets, but in this case we substituted the forage and maintained the same concentrate; in one of the diets a grass (Maralfafa [Pennisetum sp.]- M diet) was used as forage and in the other an extensively used leguminous (Alfalfa [Medicago sativa]- A diet). Methods and analysis were the same that in Experiment 1, and here we include metabolites in urine and blood plasma. The dry matter intake was higher for diet A (1.8 vs $1.6 \mathrm{~kg} / \mathrm{d}$, respectively) and digestibility coefficients were higher for diet M. However, no significant differences were shown in $\mathrm{MEl}(1089 \mathrm{~kJ} / \mathrm{kg}$ of 
$\mathrm{BW}^{0.75}$, on average) and $\mathrm{HP}\left(639 \mathrm{~kJ} / \mathrm{kg}\right.$ of $\mathrm{BW}^{0.75}$ on average). Higher milk yield was observed in $A$ diet than $M$ diet (1.8 vs. $1.7 \mathrm{~kg} / \mathrm{d}$, respectively) and metabolites in urine, plasma and milk indicated better use of diet $A$ than $M$, while no differences in milk composition were found $(5 \%$ of fat and $4.3 \%$ of protein). Methane production was higher for A diet $(28.5 \mathrm{~g} / \mathrm{d})$ than $\mathrm{M} \operatorname{diet}(25.9$ $\mathrm{g} / \mathrm{d}$ ), although these differences were not statistically significant.

In the third experiment, energy partition was compared in two sheep breeds (Manchega vs. Guirra) fed above maintenance. We fed again with mixed diets and metabolic cages, indirect calorimetry, nitrogen balance and integral calculus were the tools used for these energy partitioning approach. An approximation of division of heat production was done. ME for maintenence was estimated at $354 \mathrm{~kJ} / \mathrm{kg}$ of $\mathrm{BW}^{0.75}$ and day, on average for the two breeds. Basal metabolic rate was different between breeds; 270 vs. $247 \mathrm{~kJ} / \mathrm{kg}$ of $\mathrm{BW}^{0.75}$ for Guirra and Manchega, respectively. The heat increment of feeding was $14 \%$ of the MEl, on average for the two breeds. 


\section{Resumen}

El objetivo principal de esta tesis fue estudiar el metabolismo energético en pequeños rumiantes bajo diferentes escenarios de nutrición. Como metodología se utilizó la calorimetría indirecta en vez de calorimetría directa o pruebas de alimentación. Dentro de la calorimetría indirecta trabajamos con un sistema portátil de circuito abierto de intercambio de gases con una "urna" (Heat hood). Este sistema de circuito abierto de respiración nos permitió completar todo el balance energético y evaluar la eficiencia de la utilización de la energía de la dieta para diferentes estados fisiológicos como producción de leche en cabras u oveja en mantenimiento. Además fue posible cuantificar en cada ensayo algunas perdidas relacionadas con la contaminación ambiental como emisiones de $\mathrm{CH}_{4}$ y la excreción de nitrógeno en heces y orina.

En esta tesis se diseñaron tres experimentos, dos en cabras en lactación y otro en ovejas como describimos a continuación.

En el primer experimento se han determinado, digestibilidad, balance energético, balance carbono nitrógeno, producción de leche, parámetros ruminales, ácidos grasos y metabolitos en leche. Jaulas metabólicas y un sistema de circuito abierto de calorimetría indirecta fue el método aplicado. Los tratamientos consistieron en dos dietas mixtas con alfalfa como forraje y dentro del concentrado el grano de avena fue reemplazado por cilindro de arroz.

No se encontraron diferencias significativas en la energía metabolizable ingerida (MEI) de $1254 \mathrm{~kJ} / \mathrm{kg} \mathrm{PV} \mathrm{P}^{0.75}$ en promedio y una producción de calor (HP) de $640 \mathrm{~kJ} / \mathrm{kg} \mathrm{PV}^{0.75}$ en promedio. La producción de leche no presentó diferencias significativas entre las dos dietas, $(2,2 \mathrm{~kg} / \mathrm{den}$ promedio), la grasa de la leche fue mayor en la dieta de cilindro de arroz (6,9\% vs. 5,3\% para cilindro de arroz y avena respectivamente). El balance energético fue positivo y correlacionado a los metabolitos en leche determinados. En cuanto a las emisiones de $\mathrm{CH}_{4}$, determinadas en vivo mediante el intercambio de gases por calorimetría indirecta, las cabras alimentadas con el subproducto redujeron significativamente la producción de metano $(23,2 \mathrm{~g} / \mathrm{d}$ vs $30,1 \mathrm{~g} / \mathrm{d}$.).

En el segundo experimento, también utilizamos dos tipos de dietas, pero en este caso sustituimos los forrajes y mantuvimos el mismo pienso; en una de las dietas se utilizó como forraje una gramínea (Maralfafa [Pennisetum sp.] - 
dieta M) y en el otro una leguminosa de uso extendido (Alfalfa [Medicago sativa] - dieta A). Los métodos de análisis y análisis fueron los mismos que los utilizados en el Experimento 1, y se incluyeron además análisis de metabolitos en orina y plasma. La materia seca ingerida fue mayor para dieta $A$ (1,8 vs 1,6 $\mathrm{kg} / \mathrm{d}$, respectivamente), los coeficientes de digestibilidad fueron mayores para la dieta M. Sin embargo, no se encontraron diferencias significativas en MEI (1089 kJ/kg PV $\mathrm{PV}^{0.75}$, en promedio) y HP $639 \mathrm{~kJ} / \mathrm{kg} \mathrm{PV}{ }^{0.75}$, en promedio). La producción de leche fue mayor en la dieta $A$ que la dieta $M,(1,8$ vs. $1,7 \mathrm{~kg} / \mathrm{d}$, respectively) y los metabolitos en orina, plasma y leche indican un mejor aprovechamiento de la dieta $A$. No se presentaron diferencias en la composición de la leche ( $5 \%$ de grasa and $4.3 \%$ de proteína). La producción de metano fue mayor para la dieta $A(28,5 \mathrm{~g} / \mathrm{d})$ que para la dieta $M(25,9 \mathrm{~g} / \mathrm{d})$, aunque estas diferencias no fueron estadísticamente significativas.

En el tercer experimento se compararon la partición energética en dos razas de ovejas (Manchega vs. Guirra) en mantenimiento. Fueron alimentadas con dietas mixtas en jaulas metabólicas, calorimetría indirecta, balance carbono nitrógeno y cálculos integrales fueron las herramientas utilizadas para un aproximación de la partición energética. Se realizó una aproximación de división de producción de calor. El ME para mantenimiento se estimó en 354 $\mathrm{kJ} / \mathrm{kg} \mathrm{PV}^{0.75} /$ día, en promedio para las dos razas. Las diferencias en la tasa metabólica basal entre las razas fue de 270 vs 247 kJ/kg PV ${ }^{0.75}$ para Guirra y Manchega, respectivamente.

El incremento térmico por ingestión fue de $14 \%$ de la MEI, en promedio para las dos razas. 


\section{Resum}

El principal objectiu d'aquesta tesi va ser estudiar el metabolism energètic en xicotets ruminants baix diferents escenaris de nutrició. Com a metodologia es va utilitzar la calorimetria indirecta en compte de calorimetria directa o proves d'alimentació. Dins de la calorimetria indirecta treballarem amb un sistema portatil de circuit obert d'intercanvi de gasos amb "urna" (Heat hood). Aquest sistema de respiració de circuit obert ens va permetre completar tot el balanç energètic i avaluar l'eficiència de la utilització de l'energia de la dieta per a diferents circumstàncies fisiològiques com produccion de llet en cabres o manteniment en ovelles. A més va ser possible quantificar en cada assaig algunes perdues relacionades amb la contaminacion ambiental com a emissions de $\mathrm{CH}_{4}$ i l'excreció de nitrogen en femta i orina.

En aquesta tesi es van dissenyar tres experiments, dos en cabres en lactación i un altre en ovelles com vam descriure a continuació.

En el primer experiment s'han determinat,digestibilidad, balanç energètic, balanç carboni nitrogen, producció de llet, paràmetres ruminales, àcids grassos i metabòlits en llet. Gàbies metabòliques i un sistema de circuit obert de calorimetria indirecta va ser el mètode aplicat. Els tractaments van consistir en dues dietes mixtes amb alfals com a farratge i dins del concentrat el gra de civada va ser reemplaçat per cilindre d'arròs.

No es van trobar diferències significatives en l'energia metabolizable ingerida (MEl) de $1254 \mathrm{~kJ} / \mathrm{kg} \mathrm{PV}^{0.75}$ en mitjana i una producció de calor (HP) de $640 \mathrm{~kJ} / \mathrm{kg} \mathrm{PV}{ }^{0.75}$ en mitjana. La producció de llet no va presentar diferències significatives entre les dues dietes, $(2.2 \mathrm{~kg} /$ donen mitjana), el greix de la llet va ser major en la dieta de cilindre d'arròs (6.9\% vs. 5.3\% per a cilindre d'arròs i civada respectivament). El balanç energètic va ser positiu i correlacionat als metabòlits en llet determinats. Quant a les emissions de $\mathrm{CH}_{4}$, determinades en viu mitjançant l'intercanvi de gasos per calorimetria indirecta, les cabres alimentades amb el subproducte van reduir significativament la producció de metà (23.2 g / d vs $30.1 \mathrm{~g} / \mathrm{d}$.). 
En el segon experiment, també utilitzem dos tipus de dietes, però en aquest cas substituïm els farratges i vam mantenir el mateix pinso; en una de les dietes es va utilitzar com a farratge una gramínea (Maralfafa [Pennisetum sp.] - dieta M) i en l'altre una **leguminosa d'ús estès (Alfals [Medicago sativa] - dieta A). Els mètodes d'anàlisis $i$ anàlisis van ser els mateixos que els utilitzats en l'Experiment 1, i es van incloure a més anàlisi de metabòlits en orina i plasma. La matèria seca ingerida va ser major per a dieta $A(1,8$ vs 1,6 $\mathrm{kg} / \mathrm{d}$, respectivament), els coeficients de digestibilidad van ser majors per a la dieta M. No obstant açò no es van trobar diferències significatives en MEI (1089 $\mathrm{kJ} / \mathrm{kg} \mathrm{PV}{ }^{0.75}$, en mitjana) i HP $639 \mathrm{~kJ} / \mathrm{kg} \mathrm{PV}^{0.75}$, en mitjana). La producció de llet va ser major en la dieta Al fet que la dieta $M$, (1,8 vs. 1,7 kg/d, respectively) i els metabòlits en orina, plasma i llet indiquen un millor aprofitament de la dieta A. No es van presentar diferències en la composició de la llet $(5 \%$ de greix i $4.3 \%$ de proteïna). La producció de metà va ser major per a la dieta $A(28,5$ $\mathrm{g} / \mathrm{d})$ que per a la dieta $M(25,9 \mathrm{~g} / \mathrm{d})$, encara que aquestes diferències no van anar estadísticament significatives.

En el tercer experiment es van comparar la partició energètica en dues races d'ovelles (Manxega vs. Guirra) en manteniment. Van ser alimentades amb dietes mixtes en gàbies metabòliques, calorimetria indirecta, balanç carboni nitrogen i càlculs integrals van ser les eines utilitzades per a un aproximació de la partició energètica. Es va realitzar una aproximació de divisió de producció de calor. L'EM para manteniment es va estimar en $354 \mathrm{~kJ} / \mathrm{kg}$ $\mathrm{PV}^{0.75}$ / dia, en mitjana per a les dues races. Les diferències en la taxa metabòlica basal entre les races va ser de 270 vs 247 kJ/kg PV ${ }^{0.75}$ per a Guirra i Manxega, respectivament. L'increment tèrmic per ingestió va ser de $14 \%$ de la $\mathrm{MEI}$, en mitjana per a les dues races 



\section{Food and energy metabolism}

Animals need food to provide the energy needs to keep alive and to maintain body processes; growth, reproduction, milk production, muscle contraction and for many others processes, as raw materials for building and maintaining cellular and metabolic machinery. All animals use chemical compounds to supply energy and building materials. They must obtain these either directly by eating plants or by eating other organic materials. Therefore, the organic compounds animals need is ultimately derived from plants and thus indirectly from sunlight. Plants use the energy from sunlight and carbon dioxide $\left(\mathrm{CO}_{2}\right)$ from the atmosphere to synthesize sugars and, indirectly, all the complicated compounds that constitute a plant. The subject of food has three majors aspects; feeding, digestion and nutrition. Feeding refers to the acquisition and ingestion of food. Virtually all food consists of highly complex compounds that cannot be used without first being broken down to simpler compounds, we refer to these processes as digestion. A variety of organic compounds can provide energy, but in addition, animals have specific needs for compounds they cannot synthesize, such as amino acids and vitamins. Both, the need for food to provide energy and the need for specific food components belong to the subject of nutrition. And the study of the processes of energy transfer in animals and the regulatory mechanism involved is usually termed bioenergetics.

Most animals satisfy their energy requirements by oxidation of food materials and in the process form $\mathrm{CO}_{2}$ and water. The process of oxygen $\left(\mathrm{O}_{2}\right)$ uptake and release of $\mathrm{CO}_{2}$ is called respiration. So, animals need chemical energy to carry out their various functions, and their overall use of chemical energy is often referred to as their energy metabolism. The amount of $\mathrm{O}_{2}$ they consume can therefore be used as a measure of their energy metabolism. Many times the rate of $\mathrm{O}_{2}$ consumption means the rate of energy metabolism (Blaxter, 1989).

\section{Metabolic rate and energy metabolism determination techniques}

Metabolic rate refers to the energy metabolism per unit of time. There are different methods to estimate it. The heat produced in the oxidation of food, 
whether in the laboratory or in the body, is measured by techniques of calorimetry.

\section{II.1. Direct calorimetry}

The first calorimeter was built by Lavoisier towards the end of the $18^{\text {th }}$ century. It was a small chamber with double walls containing ice; the heat given off by an animal that was introduced inside was related to the amount of melted ice, that means, heat was trnasferred to a surrounding mass of water. Nowadays, with the development of precise techniques, more complex chambers are used.

It is a simple theory, but hard to put into practice. Calorimeters designed to measure animal heat production are based on the same general principle as the bomb calorimeter, where the heat given off is used to increase the temperature in the surrounding environment. An animal calorimeter is an isolated hermetic chamber in a double walled enclosure, with water circulating in copper pipes. The weight of water circulated per unit time multiplied by the rise in its temperature gave the heat loss by radiation and conveccion. The heat lost by the animal in vaporizing water was then estimated by multiplying the weight of water vapour by the latent heat of vaporization of water. Therefore, loss of heat from the animal can be measured directly.

This method should give information about all fuel used, and in principle it is the most accurate method. In practice, determinations are made with the animal inside a calorimeter. This can yield very accurate results, but technically it is a complex procedure.

\section{II.2. Indirect calorimetry}

As recently summarized Frankenfield (2010), the use of indirect calorimetry as a means to quantify substrate oxidation and heat production has increased rapidly since the discovery that air was a mixture of gasses by John Mayow in 1674. Pioneering work of Lavoisier (1873) demonstrate that heat production, measure by a triple ice chamber calorimeter, as we described previously, coincided with the consumption of $\mathrm{O}_{2}$ and the simultaneous production of $\mathrm{CO}_{2}$. The widespread acceptance of the first law of thermodynamics (conservation of energy in a close system) in the nineteenth 
century and the rapid technological development over the last two and a half centuries has led to indirect calorimetry being a commonly accepted technology to measure the production of heat following the oxidation of substrates in living subjects. Other important idea in calorimetry studies was based on the notion in 1838 by G.H. Hess that the heat produced in a chemical reaction is independent of the pathways between the initial and final states (Hess's law, from Blaxter, 1989). This implies that it does not make difference whether a substrate is directly oxidized completely, or whether intermediate products such as lactic acid, fatty acids, ketone bodies, are produced which are subsequently transformed and oxidized at a later stage.

There are several methods:

II.2.1. Carbon and Nitrogen balance: With this method we directly determine the retained energy (RE) in the animal and by difference with the metabolizable energy (ME) intake we will estimate heat production (HP). The amounts of protein and fat can then be estimated using the carbon $(C)$ and nitrogen $(\mathrm{N})$ balance, which is about determining the quantity of these elements ingested and eliminated from the organism, so that, by difference we can obtain the retained quantities. Next, $R E$ is calculated by multiplying the retained quantities of these elements by their corresponding energetic values. Both elements are introduced in the body of the animal through feeding. Nitrogen is eliminated exclusively through feces and urine. Meanwhile, carbon is lost as methane and carbon dioxide as well, which leads to the need to carry out this method with the help of a respiratory mask or camera.

The advantage of this method is that it is not necessary to measure oxygen intake or respiratory coefficient, and that the energy is divided into fractions of protein and fat. By the difference between the ingested ME and RE heat production can be estimated. The CN balance is frequently determined in association with measurements o indirect calorimetry (Blaxter 1967), and it depends on $\mathrm{C}$ and $\mathrm{N}$ intake values and losses as urine, feces, and gasses $\left(\mathrm{CO}_{2}\right.$ y $\mathrm{CH}_{4}$ ). $\mathrm{CN}$ method usually brings about a over-estimation of RE because the $\mathrm{CN}$ balance is usually over-estimated due to evaporation losses and others in the wastes which are not measured in totality (Just et al.1982). 
II.2.2. Comparative Slaughter: Direct determination of RE is done by forming two animal groups and slaughtering one of them at the beginning of the experiment, and the other group at the end of the trial. By means of a calorimetry bomb the energy content of the slaughtered animals is determined by using the entire ground carcass or with samples of body tissues.

With all this, a relationship between live weight and energy content is obtained, using this to predict the initial energy content of the animals in the second group. This second group is slaughtered at the end of the experiment, with the same procedure as the first. At this moment, increase in energy retention is calculated. The disadvantage of this method is its high cost and laboriousness in bigger cattle. Besides, it means a potential loss of animals. As an advantage we can mention that we can dissect each tissue and study fat, protein and energy retentions.

11.2.3. Respiration chamber, head hood and face mask: This method can be used to determine the amount of $\mathrm{O}_{2}$ used in oxidation processes. The determination of $\mathrm{O}_{2}$ consumption is technically easy and is so commonly used for estimation of metabolic rate.

The reason $\mathrm{O}_{2}$ can be used as a practical measure of metabolic rate is that the amount of heat produced for each liter of $\mathrm{O}_{2}$ used in metabolism remains nearly constant, irrespective of whether fat, carbohydrate, or protein is oxidized. The highest figure ( $21 \mathrm{~kJ}$ per liter of $\mathrm{O}_{2}$ for carbohydrate metabolism) and the lowest (19 kJ per liter of $\mathrm{O}_{2}$ for protein) differ by only $10 \%$, and it has become customary to use an average value of $20 \mathrm{~kJ}$ per liter of $\mathrm{O}_{2}$ as a measure of the metabolic rate. Therefore, this is the method used to estimate metabolic waste is starting from $\mathrm{O}_{2}$ intake, production of carbon dioxide $\mathrm{CO}_{2}$. The term indirect calorimetry implies that the heat released by chemical processes inside the organism can be calculated indirectly from the oxygen intake rate. Assuming that all the oxygen is used to oxidize degradable substrates and that all of the $\mathrm{CO}_{2}$ produced is recovered, it is possible to calculate the total energy quantity produced.

The ratio between the $\mathrm{CO}_{2}$ formed in metabolism and the $\mathrm{O}_{2}$ used is known as the respiratory quotient $(R Q)$. The $R Q$ gives information about the fuel 
used in metabolism. Usually the $R Q$ is between 0.7 and 1.0. An $R Q$ near 0.7 suggest primarily fat metabolism; and $R Q$ near 1.0 suggest primarily carbohydrate metabolism. For an intermediate $R Q$, it is more difficult to say what feedstuffs have been metabolized; it could be protein, a mixture of fat and carbohydrate, or a mixture of all three.

Consequently, indirect calorimetry is based on the quantity of heat produced by oxidation of components of feedstuffs or body and the amount of $\mathrm{O}_{2}$ consumed, $\mathrm{CO}_{2}$ and methane $\left(\mathrm{CH}_{4}\right)$ produced and nitrogen excreted in urine.

Brouwer's (Brouwer, 1965) general ecuation is:

$$
\mathrm{HP}=16.18 \mathrm{O}_{2}+5.02 \mathrm{CO}_{2}-2.17 \mathrm{CH}_{4}-5.99 \mathrm{~N}
$$

Where HP or HE is heat production $(\mathrm{kJ}), \mathrm{O}_{2}$ is the rate of oxygen intake, $\mathrm{CO}_{2}$ is the rate of carbon dioxide production, $\mathrm{CH}_{4}$ is the rate of methane production and $\mathrm{N}$ is the nitrogen excreted in urine $(\mathrm{g})$.

Methane gas produced by ruminal fermentation of organic material is expelled through the mouth chiefly in ruminants and can also be determined by indirect calorimetry.

Methane production can represent between 2 and $11 \%$ of gross energy consumed by the ruminant (Johnson y Johnson, 1995). The energy equivalent value of $\mathrm{CH}_{4}$ is $39.5 \mathrm{~kJ} / \mathrm{L}$ (according to Brouwer, 1965).

The $\mathrm{CH}_{4}$ production decrease the energy efficiency of using the energy of the diet due to $\mathrm{CH}_{4}$ being exhaled into the atmosphere. Besides, in the last decades a renewed interest in respirometry-based energy metabolism measurement has been growing, not only to learn about energy needs but as an indirect consequence of the concern to reduce greenhouse effect emissions of cattle (for example, ruminants produce about $15 \%$ of global atmospheric $\mathrm{CH}_{4}$ Moss et al., 2000)

Among types of animals, ruminants send out significantly larger quantities of $\mathrm{CH}_{4}$ than non-ruminants due to the higher population of methaneproducing microbes living on the rumen reticle (Crutzen et al., 1986; Moss et al., 2000). 
In the open circuit respiration apparatus, outdoor air is passed through the chamber and the changes in its $\mathrm{O}_{2}, \mathrm{CH}_{4}$ and $\mathrm{CO}_{2}$ content is measured. The more typical apparatus is the respiration chamber and the main problems associated are the higher cost of construction and maintenance and that the volume of air, which passes through the chamber, must be measured very precisely.

Short-term measurements of metabolism are relatively simple using a face mask and breathing to a Douglas bags. One of these devices was developed at the Polytechnic University of Valencia (Fernández et al. 2012). Besides the low cost in comparison to a respirometry chamber, the open circuit system connected to a face mask was chosen because it is the most adequate for quick-answer applications for measuring gas exchanges in animals during short periods of time (Brosh, 2007; Lachica and Aguilera, 2008).

Although it was very useful because it was portable and was possible to move it from one animal to another, the main limitations were the extrapolation to $24 \mathrm{~h}$ and that is impossible to feed the animals with the face mask on. Face masks prevent animals to be able to eat during measurements and prolonged use may cause unrest and anguish. Therefore, for long-term measurements, use of head hoods is preferred in place of face masks (Takahashi et al.1999)

Therefore, an intermediate solution is to use a head hood. A hood system is a simplification of an animal respiratory chamber, as it measures gas interchange only in the head instead of the whole body. On the other hand, it is an improvement on face masks used by Kempton et al. (1976), because gas measurements can be generated during the whole day and animals are able to have access to water and foodstuffs.

At the Polytechnic University of Valencia, Fernández et al.(2015) designed a portable indirect calorimetry system with a head hood. This system has a lot of advantages, for example, being movable it is possible to relocate and measure animals anywhere, and measurements are individual, per animal, and can provide continuous and precise data on air composition during a given time period; as contrast to chambers which measure more than one animal in a given time period.

Among some limitations we can mention is that test animals need to get used to the head hood and measurements only pick up data on enteric 
fermentation gasses and do not include flatulence rate. Although, Murray et al. (1976) estimated the hindgut fermentation in sheep $(9-11 \%$ of the energy intake) and found that most of it is absorbed and eructated.

11.2.4. Comparison among methods: In the literature, indirect calorimetry is quite often used as a reference for other methodologies for the measurements of HP. From the comparison of indirect calorimetry with comparative slaughter it appears that there may be a systematic overestimate of energy retained by indirect calorimetry. On the other hand, as comparative slaughter has to be conducted over a large range of body weights (comparative slaughter typically performed in growing subjects) and indirect calorimetry is usually performed over a week or less (quite often respiration measurements are done over a 24 or $48 \mathrm{~h}$ period), it is likely that part of the difference presented in the literature, attributed to methodological errors, may actually reflect a real difference in HP related to slightly different or varying housing conditions (Van Milgen et al. 1997).

Indirect calorimetry and $\mathrm{CN}$ methods show quite comparable results, usually leading to slightly higher estimates of HP by indirect calorimetry, leading to lower estimates of energy retention (Christensen et al., 1988). These authors said there are no reason to prefer one over the other, but it should be noted that the obvious advantage of indirect calorimetry over $\mathrm{CN}$ is that indirect calorimetry methods provide a good lead to estimate the net rate of substrate oxidation. In conclusion, $\mathrm{HP}$ can be predicted satisfactorily from the $\mathrm{O}_{2}$ consumed and $\mathrm{CO}_{2}$ produced using factors derived from the oxidation of carbohydrates, fat and protein.

\section{Energy Requirements}

Animals foodstuffs are composed by different amounts of carbohydrates, fat and proteins. Although 1 liter of $\mathrm{O}_{2}$ gives similar amounts of energy for carbohydrates, fat and protein, each gram of it gives a very different amount of energy. The energy derived from the oxidation of $1 \mathrm{~g}$ fat is more than twice as high as from the oxidation of $1 \mathrm{~g}$ carbohydrate or protein. The biologically most important consequence is that energy stored as fats adds less to the weight and is an important their determination because it can give an idea of energy 
reserves. Adipose tissue is an important resource in livestock under negative energy balance because fat reserves can be mobilized under some physiological circumstances; scarcity of food, peak lactation, etc.

In lactating goats, feeding accounts for more than $60 \%$ of total production cost (Daza, 2002). The increased use of crop resources for human consumption or fuel production in a context of constrained land resources promotes feedstuff diversification in dairy goat's diets, including the use of increasing amounts of by-products. These new feedstuffs are often poorly documented for their energy values, whereas the technological treatment they undergo, often associated with high content in dietary fiber, may strongly affect metabolic utilization of energy by the lactating goat. This situation is similar for the new forage alternatives used to fed the ruminant as well. Different feeding systems (from digestible energy to net energy, NE) that take into account different energy losses by the animal can be used to describe dietary energy value (NRC, 2007). The classical energetic hierarchy defines ME as the useable energy supplied to an animal from dietary nutrients, after accounting for fecal, gaseous and urinary losses (ARC, 1980; NRC, 1998). It has been generally accepted to express efficiencies $(k)$ in terms of $M E$, therefore; $M E=R E / k$, being $R E$ retained energy.

For example, $\mathrm{km}, \mathrm{kg}$ and $\mathrm{kl}$ represent the partial efficiencies of ME use for maintenance, tissue energy gain and lactation energy, respectively, which is calculated as the increase in energy recovered in these products with increasing ME. So, the efficiency of use of ME for milk production in MurcianoGranadina goats is around 0.67 (Aguilera et al., 1990) when goats were fed with barley and alfalfa pelleted. Recent studies using mixed diets, and the same goat breed, gives values of 0.63 (López and Fernández, 2013) but no more information is available for Spanish breeds under different feeding scenaries. The NE system requires measuring energy expenditure associated with the utilization of these feedstuffs for lactation, growth or other activity. Animal produce heat because of different metabolic processes involved in their maintenance and production functions. For instance, the direct measurement in lactating animals of heat production in respiration chamber or head hoods offers the opportunity to evaluate feedstuff and variations among animals in line with the genotype, phenotype or environmental or physiological conditions. 
The calculation of heat increment in maintenance or production in small ruminants is scarce as well. Regards to the partition of the HP for different activities, few studies are existing around the word in ruminants. Blaxter and Boyne (1978) mention that the cost for eating in sheep is less in case of cereals that in case of forage. We were found only a few studies related to the cost of eating (Lachica et al., 1997) and Lachica et al. (1999) related to the cost of locomotion in goats. Studies of the cost of eating and rumination of sheep given grass diets was investigated by Osuji et al. (1975); the heat increment in sheep during feeding increased by $40 \%-$ $80 \%$ during a course of a meal. Labussiere et al. (2008) studied in veal calves the fasting heat production and energy cost of standing.

This heat increment needs the partitioning of total HP between a component due to maintenance and a component due to lactation, growth, etc. Differences in energy expenditure due to different levels of physical activity between animals have also to be account, although no much information is existing.

Therefore, the energy balance could result like:

$$
\begin{gathered}
M E=R E+H P \\
M E=R E_{\text {fat }}+R E_{\text {protein }}+E_{\text {milk }}+H P_{\text {basal }}+H P_{\text {intake }}+H P_{\text {digestion }}+H P P_{\text {locomotion }}+\ldots
\end{gathered}
$$

Employing calorimetric techniques one can have direct access to total HP, and experimental intervention (by mean of electronic devices), and dedicated computational techniques are required to disentangle its components (Van Klinken et al., 2012).

The energy requirements information existing for lactating goats is limited, being the literature focused mainly in meat or fiber goats. No much information is obtainable in Spain for sheep as well. Furthermore, no many studies were found for Spanish small ruminant breeds related to feed energy utilization and the partition of HP in their components.

This Thesis deal with the use of food (mixed diets) to provide energy in small ruminants. The first two experiments partition the ME of the diet in retained energy (body and milk) and total HP in lactating dairy goat. Where, the first trial was focused in the concentrate and the second in the forage. The third 
trial was an attempt to exploration the partition of the total HP in different activities; basal heat production, heat production due to the act of eating and activity. Non lactating and dry sheep fed above maintenance were used in the last trial. 


\section{References}

Aguilera, J. F., Prieto, C., Fonollá, J., 1990. Protein and energy metabolism of lactating Granadina goats. Br. J. Nutr. 63:165-175.

Agricultural Research Council. 1981. The Nutrient Requirements of Farm Livestock No. 2. Ruminants, 2nd ed. Agricultural Research Council, London.

ARC (1980) The Nutrient Requirements of Ruminant Livestock. Technical Revision of the Agricultural Research Council Working Party. Commonwealth Agricultural Bureaux, Farnham Royal, UK.

Blaxter, K.L., 1967. Techniques in energy metabolism studies and their limitations. The Proceedings of the Nutrition Society. 26:86-96. doi: 10.1079/PNS19670016

Blaxter, K.L. and Boyne, A.W. (1978) The estimation of the nutritive value of feeds as energy sources for ruminants and the derivation of feeding systems. J. Agric. Sci., Camb., 90:47-68.

Blaxter, K.L., 1989. Energy Metabolism in Animals and Man. Cambridge, UK Cambridge Univ. Press.

Brosh, A., 2007. Heart rate measurements as an index of energy expenditure and energy balance in ruminants: a review. J. Anim. Sci. 85:1213-1227.

Brouwer, E., 1965. Report of sub-committee on constants and factors. In: Blaxter, K.L. (Ed.), Proceedings of the Third EAAP Symposium on Energy Metabolism. Publication No. 11. Academic Press, London, pp. 441-443.

Christensen, K., Chwalibog, A., Henckel, S., Thorbek, G., 1988. Heat production in growing pigs calculated according to the $R Q$ and $C N$ methods. Comparative Biochemistry and Physiology 91:463-468. doi:10.1016/ 03009629(88)90619-6

Crutzen, P.J., Aselman, I., Seiler, W., 1986. Methane Production by Domestic Animals, Wild Ruminants, other Herbivorous Fauna, and Humans. Tellus, 38: 271-284.

Daza, A., 2002. Mejora de la productividad y planificación de explotaciones ovinas. Ed. Agrícola Española, 232 pp. 
Fernandez, C., Lopez, M.C., Lachica, M., 2012. Description and function of a mobile open-circuit respirometry system to measure gas exchange in small ruminants. Anim. Feed Sci. Technol. 172:242-246.

Fernández, C., López, M.C., Lachica, M., 2015. Low cost open-circuit hood system for measuring gas exchange in small ruminants: from manual to automatic recording. J. Agri. Sci. 153:1302-1309.

Frankenfield, D.C., 2010. On heat, respiration, and calorimetry. Nutricion. 26:939-950.

Johnson, K. A., and D. E. Johnson. 1995. Methane emissions in cattle. J. Anim. Sci. 73:2483-2492.

Just, A., Fernández, J.A., Jorgensen, H., 1982. Nitrogen balance studies and nitrogen retention. In: LaPlace, JP., Corring, J., Rerat, A. (Eds.), 2nd Int. Seminar Jouy-en-Jonas, Digestive Physiology in the Pig. France, pp. 111-112.

Kempton, T.J., Murray, R.M., Leng, R.A., 1976. Methane production and digestibility measurements in the grey kangaroo and sheep. Aust. J. Biol. Sci. 29:209-14.

Labussiere, E., Dubois, S., van Milgen, J., Bertrand, G., Noblet, J., 2008. Fasting heat production and energy cost of standing activity in veal calves. British Journal of Nutrition 100:1315-1324.

Lachica, M., Prieto, C., Aguilera, J.F., 1997. The Energy of Walking on the Level and on Negative and Positive Slopes in the Granadina Goat (Capra hircus). British Journal of Nutrition, 77: 73-81. http://dx.doi.org/10.1017/S0007114500002890

Lachica, M. and Aguilera, J.F., 2008. Methods to estimate the energy expenditure of goats: From the lab to the field. Small Rum. Res. 79, 179182.

López, M.C., Fernández, C., 2013. Energy partitioning and substrate oxidation by Murciano-Granadina goats during mid lactation fed soy hulls and corn gluten feed blend as a replacement for corn grain. Journal of Dairy Science 96:4542-4552.

Moss, A.R., Jouany, J.P., Newbold, J., 2000. Methane production by ruminants: its contribution to global warming. Ann. Zootech., 49: 231- 253. 
Murray, R. M., A.M.Bryant, R. A. Leng. 1976. Rates of production of methane in the rumen and large intestine of sheep. Br. J. Nutr. 36:1-14.

National Research Council (NRC), 1998. Nutrient Requirements of Swine: 10th Revised Edition. National Academies Press, Washington, D.C.

National Research Council (NRC), 2007. Nutrient Requirements of Small Ruminants. Sheep, Goats, Cervids and New World Camelids. National Academy Press, Washington, D.C.

Osuji, P.O., Gordon, J.G. and Webster, A.J.F. (1975) Energy Exchanges Associated with Eating and Rumination of Sheep Given Grass Diets of Different Physical Form. British Journal of Nutrition, 34, 59-71.

Takahashi, J., Chaudhry, A.S., Beneke, R.G., Young, B.A., 1999. An opencircuit hood system for gaseous exchange measurements in small ruminants. Small Ruminant Research 32:31-36. doi:10.1016/S09214488(98)00163-1

Van Klinken, J.B., Van den Berg, S.A.A., Havekes, L.M., Van Dijk, K.W., 2012. Estimation of Activity Related Energy Expenditure and Resting Metabolic Rate in Freely Moving Mice from Indirect Calorimetry Data. PLoS ONE, 7, e36162. http://dx.doi.org/10.1371/journal.pone.0036162

Van Milgen, J., Noblet, J., Dubois S., Bernier, J.F., 1997. Dynamic aspect of oxygen consumption and carbon dioxide production in swine. British Journal of Nutrition 78:397-410. 

OBJETIVES 



\section{Experiment I}

To study the effects of substituting oat grain with rice bran on energy, nitrogen and carbon balance, methane emissions, and milk performance in dairy goats.

\section{Experiment II}

To study the effects of substituting alfalfa (Medicago sativa) with maralfalfa (Pennisetum sp.) on energy, nitrogen and carbon balance, methane emission, and milk performance in dairy goats.

\section{Experiment III}

To compare the partition of heat energy (HP) in two sheep breeds combining indirect calorimetry and integral calculus. 



\section{EXPERIMENT 1}

Effect of rice bran as a replacement for oat grain in energy and nitrogen balance, methane emissions, and milk performance of Murciano-Granadina goats.

Journal. Dairy Science. 99 (2015) 1-11. Doi: 10.3168/jds.2015-9472 

Effect of rice bran as a replacement for oat grain in energy and nitrogen balance, methane emissions and milk performance of Murciano-Granadina goats

\author{
P. Criscioni and C. Fernández ${ }^{1}$ \\ ACUMA Research Center. Animal Science Department. Polytechnic University \\ of Valencia. 46022 Valencia. Spain. \\ ${ }^{1}$ Correspondence: Carlos Fernández. ACUMA Research Center. Polytechnic \\ University of Valencia. 46022 - Valencia-Spain (email: \\ cjfernandez@dca.upv.es).Tel: +00 34963877007
}





\subsection{Abstract}

The objective of this experiment was to study the effects of substituting oat grain with rice bran on energy, nitrogen and carbon balance, methane emission, and milk performance in dairy goats. Ten Murciano-Granadina dairy goats in late lactation $(46.1 \pm 3.07 \mathrm{~kg})$ were selected in a 2 treatments in a crossover design experiment where each goat received both treatments in 2 periods. One group of five goats was fed a mixed ration with $379 \mathrm{~g}$ of oat grain $/ \mathrm{kg}$ of DM (O diet) and the other diet replaced oat grain with $379 \mathrm{~g} / \mathrm{kg} D M$ of rice bran (RB diet). Diets were formulated to be isoenergetic and isoproteic, so bypass fat was added to reach the same amount of energy in both diets. The goats were allocated to individual metabolism cages. After 14 days of adaptation, feed intake, total fecal and urine output and milk yield were recorded daily over a 5 days period. Then, gas exchange measurements were recorded individually by a mobile open-circuit indirect calorimetry system using a head box. Dry matter intake was different for both diets (1.83 \pm 0.11 vs. $1.61 \pm$ 0.08 , for $O$ and $R B$ respectively). The metabolizable energy intake and heat production were not significant between diets with average values of 1,254 $(\mathrm{SEM}=110.0)$ and $640(\mathrm{SEM}=21.0) \mathrm{kJ} / \mathrm{kg}$ of $\mathrm{BW}^{0.75}$, respectively. Significant differences were found in milk fat content $(5.3 \%$ and $6.9 \%$, SEM $=0.36$; for $O$ and $\mathrm{RB}$ respectively) and milk fatty acids; medium chain fatty acids (17.17 vs. $12.90 \mathrm{~g} / 100 \mathrm{~g}, \mathrm{SEM}=0.969$; for $\mathrm{O}$ and $\mathrm{RB}$, respectively) and monounsaturated fatty acids (20.63 vs. $28.29 \mathrm{~g} / 100 \mathrm{~g}, \mathrm{SEM}=1.973$; for $\mathrm{O}$ and $\mathrm{RB}$, respectively). The enteric $\mathrm{CH}_{4}$ emission was lower in RB treatments $(23.2 \mathrm{~g} / \mathrm{d}$ vs. $30.1 \mathrm{~g} / \mathrm{d}$, $\mathrm{SEM}=2.14$; for $\mathrm{O}$ and $\mathrm{RB}$ respectively), probably due to the higher lipid content in diets $\mathrm{RB}$ than $\mathrm{O}(11.7 \%$ vs. $4.1 \%$, respectively). Lactating goats utilized RB without detrimental effect on energy metabolism. Higher milk fat and lower $\mathrm{CH}_{4}$ emissions were observed with the RB diet compared with the $\mathrm{O}$ diet.

Key words: lactating goats, rice bran, energy balance, methane emissions. 



\subsection{Introduction}

Most of the concentrates for dairy ruminants are based on cereals. Cereal grains are the most common sources of readily available energy for livestock and comprise up to $60 \%$ of the total diet for high yielding dairy ruminants. On the other hand, given the ability of ruminal microorganism to degrade fiber, some byproducts of other agricultural and industrial process are used to replace the cereal (starch is replaced with highly digestible fibers as a main source of energy). One such byproduct is rice bran, with and estimated world production of 50 million tonnes (FAOSTAT, 2014).

Rice bran is obtained from the grain milling process, representing $5-8 \%$ of the total grain. Chemical analysis of rice bran varies widely among the nutrients, containing $11-14 \% \mathrm{CP}, 16-21 \% \mathrm{NDF}, 21-28 \%$ of starch and minerals such as iron (0.015\%), phosphorus (1.35\%) and magnesium (0.80\%). Rice bran differs from other by-products in having higher levels of ether extract (EE); 12$18 \%$. The main fatty acids in rice bran oil are palmitic (21-26\%), linoleic (3133\%) and oleic (37-42\%) (Warren and Farrell, 1990; Oliveira et al., 2011).

Rice byproducts (rice straw, rice bran, heat rice bran, defatted rice bran) have been studied in cattle, sheep and steers (Forster et al., 1994; Cao et al., 2010; Zhao et al., 1996). The effects of include rice bran on mixed diets upon intake, digestibility, energy, nitrogen (N) carbon (C) balance, and milk performance of lactating goats have not been well investigated. Therefore, our aim was compare 2 mixed diets containing the same forage and replacing oat grain with rice bran in the concentrate.

\subsection{Materials and methods}

The experimental procedures were approved by the Committee on Animal Use and Care at the Polytechnic University of Valencia, Valencia (Spain), and follow the codes of practice for animals used in experimental works proposed by the EU (2003).

\subsubsection{Animal and diets}

The experiment was conducted at the Animal Science Department Experimental Farm (ACUMA Research Center, Valencia, Spain). Ten multiparous mature Murciano-Granadina-dairy goats in late lactation were 
selected and divided into two homogenous groups of five goats based on similar body weight $(46.1 \pm 3.07 \mathrm{~kg}$ of $\mathrm{BW})$, milk production in previous lactations (661.5 $\pm 44 \mathrm{~kg}$ of milk per $210 \pm 30$ days of lactation, on average) and milk yield at the beginning of the experiment $(2375 \pm 375.1 \mathrm{~g}$ of milk per day, on average), in a crossover design (2 treatments crossed with 2 period). Treatments consisted of two different mixed rations (Table 1.1). Goats were fed daily with $0.800 \mathrm{~kg}$ alfalfa hay and $1.5 \mathrm{~kg}$ concentrate (the ratio forage and concentrate was $35 / 65$, expressed as percentage). The concentrate and premix were mixed and pelleted. One group was fed concentrate with $379 \mathrm{~g} / \mathrm{kg} \mathrm{DM}$ of oat grain ( $\mathbf{O}$ diet) and the other with rice bran (RB diet). Nutrient requirements followed the recommendation of Lachica and Aguilera (2003) and Calsamiglia et al. (2009) for goats in lactation. In the attempt to have isoenergetic diets, bypass fat was added to each diet, i.e. diets were formulated on energy bases using book values for chemical composition of ingredients (FEDNA, 2010). The chemical composition of oats, rice bran and the whole mixed diet (forage and pelleted concentrate) is reported in Table 1.1. After feed manufacturing and chemical analyses of diets, we found that the diets were not isoenergetic and the RB diet had greater gross energy value. Half the daily ration was offered at $0800 \mathrm{~h}$ and half at $1600 \mathrm{~h}$, respectively. Goats had free access to water.

\subsubsection{Experimental Schedule and Measurements}

Apparent total-tract digestibility, gas exchange, energy partitioning, $\mathrm{C}$ and $\mathrm{N}$ balance, oxidation of nutrients and milk composition and yield were determined. The experiment was conducted in a crossover design in two 30-d periods. During the adaptation, goats were fed the experimental diets in pens for $7 \mathrm{~d}$ and then allocated to individual metabolism cages at thermoneutrality (20-23 ํ determined by a Hobo ,data loggers, Onset Corp., Cape Cod, MA) for another $7 \mathrm{~d}$. Next, data on amounts of feed offered and refused and the total fecal, urine and milk output were recorded daily for each goat during a 5-d period, BW was recorded at the beginning and end of the period. Feces were collected in wire-screen baskets placed under the floor of the metabolism crates, and urine was collected through a funnel into plastic buckets containing $100 \mathrm{~mL} 10 \%$ (vol/vol) of $\mathrm{H}_{2} \mathrm{SO}_{4}$ to acidify the urine of each goat. The acidification of urine was necessary to prevent microbial degradation and the 
loss of volatile ammonia- $\mathrm{N}\left(\mathbf{N H}_{3}-\mathbf{N}\right)$. Representative samples (10\%) of diet, feces and urine were collected over 5 consecutive days, stored at $-20{ }^{\circ} \mathrm{C}$ and pooled for chemical analysis. The goats were milked once daily at $0800 \mathrm{~h}$ with a portable milking machine (Flaco, model DL-170, J. Delgado S.A., Ciudad Real, Spain). Immediately after milking, the individual milk yield was measured and a sample of $10 \%$ was placed in a bottle and frozen until analysis. In addition, samples were collected into plastic vial that contained $20 \mathrm{mg}$ of potassium dichromate as a preservative and taken to the Interprofessional Dairy Laboratory of the Valencia Community Region (LICOVAL, Valencia, Spain) for compositional analysis (DM, CP, fat and lactose). Ruminal fluid samples were collected by stomach tube before the morning feeding on the last day of the apparent digestibility trial. Ruminal fluid $\mathrm{pH}$ was immediately determined using a Model 265A portable pH meter (Orion Research Inc., Beverly, MA, USA). A ruminal fluid sample was acidified with $50 \% \mathrm{H}_{2} \mathrm{SO}_{4}$ and frozen until later determination of $\mathrm{NH}_{3}-\mathrm{N}$. Samples for analysis of VFA were mixed with $\mathrm{H}_{3} \mathrm{PO}_{4}$ and kept frozen until analysis.

Gas exchange was measured for each goat during $24 \mathrm{~h}$ (5 goats / treatment) by an indirect calorimetric system based on a ventilated head-box designed for small ruminants. To this end, $10 \mathrm{~d}$ were taken for each period in the incomplete cross over design. The respirometry system is equipped with a head hood, a flow meter (Thermal Mass Flowmeter Sensyflow VT-S, ABB, Alzenau, Germany) and air suction provided by a centrifugal fan (CST60 Soler Palau Inc., Parets del Vallès, Barcelona, Spain). The concentration of methane $\left(\mathrm{CH}_{4}\right)$ and carbon dioxide $\left(\mathrm{CO}_{2}\right)$ were measured using the infrared principle and oxygen $\left(\mathrm{O}_{2}\right)$ was measured by the paramagnetic principle (Easyflow Gas Analyzer, model 3020, ABB, Alzenau, Germany). Although the unit was an autocalibrated model, the analyzers were calibrated with reference gases before each test. Fernández et al. $(2012 ; 2015)$ described the mobile opencircuit respirometry system used for these measurements. The whole system was calibrated by injecting pure $\mathrm{N}_{2}$ and $\mathrm{CO}_{2}$ into the head box (McLean and Tobin, 1987), determined gravimetrically using a precision scale (MOBBA miniSP $0.2-30 \mathrm{~kg}$, Industrial Weighing System, Barcelona, Spain). Calibration factors were calculated according to Brockway et al. (1971). Production of $\mathrm{CH}_{4}$ 
and $\mathrm{CO}_{2}$ and consumption of $\mathrm{O}_{2}$ were calculated as described by Aguilera and Prieto (1986). An initial atmospheric air sample was collected and the gas concentrations were used as reference for calculations.

\subsubsection{Chemical Analyses}

Samples of feed, feed refusal and feces samples were first dried in a forced-air oven at $55{ }^{\circ} \mathrm{C}$ for $48 \mathrm{~h}$ then ground to pass a $1 \mathrm{~mm}$ screen before analysis. Urine and milk were dried by lyophilization. Chemical analyses of the diet, refusals and feces were conducted according to AOAC International (2000) for DM (method 934.01), ash (method 942.05) and EE (method 920.39). The DM of diets and feces was determined by oven-drying at $102 \pm 2{ }^{\circ} \mathrm{C}$ for $24 \mathrm{~h}$. Ash concentration was measured by incineration in an electric muffle furnace at $550 \stackrel{\circ}{\circ}$ for $6 \mathrm{~h}$. Ether extract was extracted with petroleum ether after acid hydrolysis to recover saponified fat (Soxtec System HT Tecator, Hillerød, Denmark; 1047 Hydrolyzing Unit and 1043 Extraction Unit). The NDF and ADF were measured in an ANKOM Fiber Analyzer (A220, ANKOM Technologies, Fairport, NY, USA) according to Mertens (2002) and AOAC International (2000), respectively. The NDF was determined using sodium sulfite and alpha amylase.

The NFC content of diets was calculated by difference method based on chemical analysis of individual feeds according to NRC (2001): NFC $=100-$ NDF - ash - CP - EE. The gross energy (GE) content of the dried samples (feed, feces, urine and milk) was analyzed by combustion in an adiabatic bomb calorimeter (Gallenkamp Autobomb; Loughborough, UK). Starch content was determined by enzymatic method ( $\alpha$-amylase obtained from Sigma-Aldrich, Steinheim, Germany) according to Batey (1982). The $C$ and N were analyzed by the Dumas principle (TruSpec CN; LECO Corporation, St. Joseph, MI, USA). Multiplying $\mathrm{N}$ by a factor of 6.25 converted the results to $\mathrm{CP}$.

Milk composition (fat, protein, lactose, citrate and total milk solids content) was analyzed with an infrared analyzer (MilkoScan FT120 Foss Electric, Hillerød, Denmark). Fatty acid (FA) methyl esters of total milk lipids were prepared directly as previously described O'Fallon et al. (2007). The FA methyl esters were analyzed in a Focus Gas Chromatograph (Thermo, Milan, Italy) equipped with a split/splitless injector and a flame ionization detector. 
Separation of methyl esters was performed in a fused silica capillary column $\mathrm{SP}^{\mathrm{TM}} 2560$ (Supelco, PA, USA) (100 m x $0.25 \mathrm{~mm} \times 0.2 \mu \mathrm{m}$ film thickness). The carrier gas was Helium at a linear velocity of $20 \mathrm{~cm} / \mathrm{s}$. The samples were injected with a split ratio of $1 / 100$. The initial oven temperature was set at 140 ${ }^{\circ} \mathrm{C}$ held for $5 \mathrm{~min}$ and increased to 240 at $4{ }^{\circ} \mathrm{C} / \mathrm{min}$ and finally maintained at that temperature for $30 \mathrm{~min}$. Both detector and injector temperatures were set at 260 ${ }^{\circ} \mathrm{C}$. A subset of milk samples was collected and analyzed for B-hydroxybutyrate (BHBA), glucose, uric acid and milk urea. Milk BHBA was analyzed using the enzymatic oxidation of the metabolite, a coupled reaction was determined by fluorometry (Larsen and Nielsen, 2005). Milk urea acid was analyzed following procedures described by Larsen and Moyes (2010). Milk urea was analyzed using flow injection analyses following the manufacturer instructions (Foss Tecator AB, Höganäs, Sweden). Glucose was determined according to standard procedures (Siemens Diagnostics Clinical Methods for ADVIA 1650) using an autoanalyzer (ADVIA 1650 Chemistry system, Siemens Medical Solutions, Tarrytown, NY).

The $\mathrm{NH}_{3}-\mathrm{N}$ content of ruminal fluid samples was analyzed by the Kjeldahl procedure (2300 Kjeltec Analyzer Unit Foss Tecator, Hillerød, Denmark). Determination of ruminal VFA was based on the method described by Jouany (1982) using a gas chromatograph (Fisons 8000 series; Fisons Instruments $\mathrm{SpA}$, Milan, Italy) equipped with a split/splitless injector and flame ionization detector.

\subsubsection{Calculations}

Metabolizable energy intake (MEI) was calculated as the difference between GE intake and energy losses in feces, urine and $\mathrm{CH}_{4}$ (with an energy equivalent value of $39.5 \mathrm{~kJ} / \mathrm{L} \mathrm{CH}_{4}$; Brouwer, 1965).

Heat production (HP) was determined from measurements of $\mathrm{O}_{2}$ consumption, $\mathrm{CO}_{2}$ and $\mathrm{CH}_{4}$ production, and urine $\mathrm{N}\left(\mathbf{N}_{\text {urine }}\right)$, using the equation of Brouwer (1965):

$$
\mathrm{HP}(\mathrm{kJ})=16.18 \times \mathrm{O}_{2}+5.02 \times \mathrm{CO}_{2}-2.17 \times \mathrm{CH}_{4}-5.99 \times \mathrm{N}_{\text {urine }}
$$


Where gases were expressed in liters per day and $N_{\text {urine }}$ in grams per day. The body tissue energy ( $\mathbf{R E}_{\text {body }}$ ) was calculated as MEI - HP - milk energy $\left(\mathbf{E}_{\text {milk }}\right)$.

The energy associated with the oxidation of protein (OXP), carbohydrate (OXCHO) and fat (OXF) was calculated by the method of Brouwer (1958) and Chwalibog et al. (1997) for ruminants. The $\mathrm{CO}_{2}$ production from oxidation $\left(\mathbf{C O}_{2 \mathbf{x}}\right)$ was calculated as $\mathrm{CO}_{2}-\left(2 \times \mathrm{CH}_{4}\right)$, according to Fahey and Berger (1988). The calculations were carried as follows:

$$
\begin{aligned}
& \mathrm{OXP}=6.25 \times \mathrm{N}_{\text {urine }} \times 18.42(\mathrm{~kJ} / \mathrm{g}) \\
& \mathrm{OXCHO}=\left(-2.968 \times \mathrm{O}_{2}+4.174 \times \mathrm{CO}_{2 \mathrm{x}}-2.446 \times \mathrm{N}_{\text {urine }}\right) \times 17.58(\mathrm{~kJ} / \mathrm{g}), \\
& \mathrm{OXF}=\left(1.719 \times \mathrm{O}_{2}-1.719 \times \mathrm{CO}_{2 x}-1.963 \times \mathrm{N}_{\text {urine }}\right) \times 39.76(\mathrm{~kJ} / \mathrm{g})
\end{aligned}
$$

Then, the HP from oxidation (HPx) was:

$$
\mathrm{HPx}(\mathrm{kJ})=16.18 \times \mathrm{O}_{2}+5.02 \times \mathrm{CO}_{2 x}-5.99 \times \mathrm{N}_{\text {urine }}
$$

Again, gases were expressed in liters per day and $N_{\text {urine }}$ in grams per day. Heat of fermentation (HPf) was estimated subtracting HP from HPx. The non protein respiratory quotient from oxidation of nutrients (RQnpx) was determined as: $R Q n p x=\left(\mathrm{CO}_{2 x}-\left(\mathrm{N}_{\text {urine }} \times 6.25 \times 0.774\right)\right) /\left(\mathrm{O}_{2}-\left(\mathrm{N}_{\text {urine }} \times 6.25 \times\right.\right.$ $0.957)$ ). For $\mathrm{C}$ and $\mathrm{N}$ balance, we followed the equations and values proposed by McLean and Tobin (1987), and the grams retained in protein ( $\mathbf{R}_{\text {protein }}$ ) and fat $\left(\boldsymbol{R}_{\text {fat }}\right)$ were calculated.

The efficiency of use of ME for lactation was calculated according to AFRC (1993). Energy lost from the body, indicating mobilization of body fat reserves in support of milk secretion, was assumed to be used for milk synthesis with an efficiency of 0.84 and the concomitant energy storage during lactation was taken to be 0.95 times the milk secretion efficiency.

Consequently, the corrected milk energy was estimated as $E_{\text {milk }}+(0.84 x$ negative energy retention $)+(1.05 \times$ positive energy retention). The efficiency of 
use of ME for milk production ( $\left.\mathbf{k}_{\mathbf{l}}\right)$ was calculated as corrected milk energy/(ME $M E_{m}$ ), with $M E_{m}$ being the metabolizable energy for maintenance, which was obtained from the estimation of Aguilera et al. (1990) for Granadina goats from both positive and negative energy retentions $\left(401 \mathrm{~kJ} / \mathrm{kg}\right.$ of $\left.\mathrm{BW}^{0.75}\right)$. Net energy for lactation $\left(\mathrm{NE}_{\mathrm{L}}\right)$ was computed as MEI $\mathrm{x} \mathrm{k}_{\mathrm{l}}$.

\subsubsection{Statistical Analyses}

The effects of substitution oat with rice bran on intake, digestibility, ruminal fermentation, milk performance, energy and C-N balances, and oxidation of nutrients were analyzed using the PROC MIXED of SAS (2001). The experiment was conducted as a crossover design: each goat received both treatments in 2 periods; goat served as the experimental unit for all data. The model for the dependent variables included the fixed effect of diet and period with goat as random effect.

The following statistical model was used: $Y=\mu+D+T+$ goat $+\varepsilon$ where $Y$ is the dependent variable, $\mu$ is the overall mean, and $D$ and $T$ are the fixed effects of diet and period of time, respectively; goat is the random effect of goat; and $\varepsilon$ is the random error. Least squares means are reported throughout and differences were considered significant at $\mathrm{P}<0.05$.

\subsection{Results and Discussion}

No significant effect was observed for the period of time in the crossover design. The average value for the calibration factor was $1.0055 \pm 0.00139$ ( $n=$ 5) and $0.9936 \pm 0.00953(\mathrm{n}=5)$ for $\mathrm{O}_{2}$ and $\mathrm{CO}_{2}$, respectively.

\subsubsection{Feed Intake, Digestibility and Rumen Fermentation}

The mixed diets were formulated based on book values of FEDNA (2010) to reach isoenergetic and isoproteic balance (average values of $15.7 \%$ of CP on DM basis). However, after feed manufacturing, samples of each diet were analyzed in the laboratory and we found out that the diets were not isoenergetic and the RB diet presented greater gross energy values (17.9 \pm 0.89 vs. $19.4 \pm$ $1.17 \mathrm{MJ} / \mathrm{kg} \mathrm{DM}$ in $\mathrm{O}$ and $\mathrm{RB}$ diets, respectively). The main difference among diets was the source of carbohydrate in oat grain and rice bran, although RB diet had double of bypass fat than $\mathrm{O}$. Rice bran has a large proportion of broken 
rice (starch), oil and protected protein (Elliot et al., 1978). The chemical composition (Table 1.1) was not maintained equal and NDF, ADF, NFC and starch was lower in $\mathrm{RB}$ than $\mathrm{O}$ diet. Regarding $\mathrm{EE}$, it was greater in $\mathrm{RB}$ than $\mathrm{O}$ ( $11.7 \%$ vs. $4.1 \%$, respectively).

Intake and total-tract apparent digestibility of nutrients by dairy goats during late lactation are shown in Table 1.2. Dry matter intake differed $(p<$ $0.05)$ between diets $(1.83 \pm 0.11$ vs. $1.61 \pm 0.08 \mathrm{~kg} / \mathrm{d}$, for $O$ and RB respectively) possibly due to the fact the animals' intake was regulated by energy requirements, so less of the richest diet was eaten.

Also, the high content of fat on diet RB reduced DMI as has been indicated by other authors supplementing rice bran oil in dairy cows because reduced gut motility (Lansing et al., 2012). No differences were found on DM apparent digestibility with a value for RB diet of $73.9 \%$ (SEM $=1.57$ ), similar to the rice bran value of $70 \%$ found by Van Soest (2006). When $O$ was replaced with RB, apparent digestibility coefficients of fiber were higher $(p<0.05)$ in RB than $\mathrm{O}(48.7 \%$ vs. $34.7 \%$, SEM $=4.42$; for NDF respectively, and $48.1 \%$ vs. $35.0 \%, \mathrm{SEM}=4.16$; for ADF respectively).

High fat content in the diet decreases $\mathrm{OM}$ and fiber degradability and reduces fermentable substrate. It is expected that high levels of fat should inhibit fiber digestion, possibly by coating food particles and preventing bacterial attachment (Palmquist and Jenkins, 1980). In the present work, RB diet showed an increased fiber digestibility despite it had $11.7 \%$ of fat, and could be associated to the lower amount of fiber and DMI in RB diet than O diet (see Table 1.1 and 1.2, respectively). Zhao et al. (1996) reported, in steers, that the addition of fat to high concentrate diets containing 12\% ADF could have shifted the site of $\mathrm{OM}$ digestion from the rumen to the intestine in steers. Higher digestibility $(p<0.05)$ was found in RB than $O$ for fat $(79.8 \%$ vs. $67.2 \%, S E M=$ 3.68; respectively) and the digestibility of starch was almost complete.

Results from rumen liquor samples are shown in Table 1.3. The average rumen $\mathrm{pH}$ never fell below 6.2, so the values obtained can be considered sufficiently high to maintain normal rumen fermentation (Ørskov and Fraser, 1975). Goats fed O (slightly greater amount of structural and non structural 
carbohydrates and lower fat than RB) presented higher $\mathrm{pH}(\mathrm{p}<0.05)$ and lower $\mathrm{NH}_{3}-\mathrm{N}(\mathrm{p}<0.05)$ concentration compared with $\mathrm{RB}(15.8 \mathrm{vs} .23 .3 \mathrm{mg} / \mathrm{dL}, \mathrm{SEM}=$ 2.00; for $\mathrm{O}$ and $\mathrm{RB}$, respectively). No effect of treatment on VFA was observed, and differences in $\mathrm{NH}_{3}-\mathrm{N}$ concentration might suggest partial inhibition of microbial synthesis by the rice bran fat. The ruminal $\mathrm{NH}_{3}-\mathrm{N}$ and VFA values from our study were within the range of those found in others studies with goats fed by-products (Romero-Huelva et al., 2012). Therefore, the lower ammonia-N results for diet $O$ than $R B$ suggests more fermentation activity. We recognize that the starch in rice bran escapes rumen fermentation almost entirely and also drives fat and bypass protein to the duodenum (Elliot et al., 1978).

\subsubsection{Energy Balance}

Daily energy balance obtained with the two diets is listed in Table 1.4. No statistically significant differences were observed for GE intake $(1,833 \pm 137.1$ $\mathrm{kJ} / \mathrm{kg}$ of $\mathrm{BW}^{0.75}$, on average) and the rest of energy partition, with exception of feces and $\mathrm{CH}_{4}$. Energy losses in feces were higher $(p<0.05)$ for $O$ than $\mathrm{RB}$, probably associated to greater DMI. Urine energy losses were not significantly different between treatments. The $O$ diet presented significant differences $(p<$ $0.05)$ on energy losses in $\mathrm{CH}_{4}\left(95 \mathrm{~kJ} / \mathrm{kg}\right.$ of $\left.\mathrm{BW}^{0.75}\right)$ than $\mathrm{RB}$ diet $(73 \mathrm{~kJ} / \mathrm{kg}$ of $\mathrm{BW}^{0.75}$ ), indicating that increasing the level of lipids in diet reduced the $\mathrm{CH}_{4}$ production, as indicated by different authors and reviewed by Knapp (2014). No differences between treatments were observed for MEI $\left(1,254 \mathrm{~kJ} / \mathrm{kg}\right.$ of $\mathrm{BW}^{0.75}$, on average; $S E M=110.0)$. The HP values from our study $(P=0.63 ; 640 \mathrm{~kJ} / \mathrm{kg}$ of $\mathrm{BW}^{0.75}$, on average; $\mathrm{SEM}=21.0$ ) are within the range of some literature values; for example, Bava et al. (2001) found an average value of $642 \mathrm{~kJ} / \mathrm{kg}$ of $\mathrm{BW}^{0.75}$ for Saanen goats fed mixed diets in late lactation. Tovar-Luna et al. (2010) fed Alpine goats during late lactation with $60 \%$ of concentrate found values of $680 \mathrm{~kJ} / \mathrm{kg}$ of $\mathrm{BW}^{0.75}$. The tissue energy recovered in the body was positive and did not differ between diets $\left(107 \mathrm{~kJ} \mathrm{RE}_{\text {body }} / \mathrm{kg}\right.$ of $\mathrm{BW}^{0.75}, \mathrm{SEM}=$ 68.4).

No significant differences were observed between diets for $k_{l}$ ( 0.72 on average). The value obtained in the present work was similar to the reported by Bava et al. (2001) in Saanen goats (0.73). Aguilera et al. (1990) and TovarLuna et al. (2010) found lower values (0.67 and 0.63, respectively). The 
increase in $\mathrm{kl}$ with increasing dietary fat is well established in the literature and has been traditionally attributed to a decrease in the heat increment of feeding and the relatively low energy cost of the transfer of absorbed fatty acids to milk fat when compared with the cost of the novo synthesis of fatty acids (Moraes et al. 2015). Furthermore, in our study we assumed a value of $401 \mathrm{~kJ} / \mathrm{kg}$ of BW $\mathrm{BW}^{0.75}$ for $\mathrm{ME}_{\mathrm{m}}$, but animals in late lactation have lower production and lower metabolic activity of visceral organs for maintenance (i.e. lower MEm, than animals in earlier lactation stage). So, these both reasons would probably clarify the highest $k_{l}$ obtained in our experiment. Net energy for lactation was expressed as megajoules per kilogram of DM and significant values of $8.4 \pm 0.42$ and 10.2 \pm 0.41 were found in $O$ and RB mixed diets, respectively.

\subsubsection{Oxidation of Nutrients}

The proportional contribution to HPx due to oxidation of nutrients is shown in Table 1.5. Diet had no significant effect on $\mathrm{HPx}\left(623 \mathrm{~kJ} / \mathrm{kg}\right.$ of $\mathrm{BW}^{0.75}$, on average; SEM $=20.2$ ). Numerically lower HPf was found in RB than O, probably linked to the higher fat content in the RB diet $(11.7 \%)$, as we mentioned previously.

The oxidation of nutrients as OXCHO increased $(p<0.05)$ from $15 \%$ to $33 \%$ in diet RB and $\mathrm{O}$, respectively (SEM $=4.5$ ). Consequently, the OXF decreased $(p<0.05)$ from $64 \%$ to $48 \%$ in RB and O, respectively (SEM $=4.3)$.

A significant difference $(p<0.05)$ was observed for RQnpx, being significantly lower for RB $(0.77)$ than $\mathrm{O}(0.83)$ with an SEM of 0.015 . Chwalibog et al. (1997) reported that RQnpx lower than 1 indicates predominance of OXF vs. OXCHO, and under positive energy balance, part of the OXF should originate from ingested carbohydrate (mainly fiber) and diet fat content.

\subsubsection{Carbon and Nitrogen Balance}

The daily $\mathrm{C}$ and $\mathrm{N}$ balance and the calculated tissue recovered as protein and fat are displayed in Table 1.6. No significant differences were observed in $C$ intake, feces and urine. Following the trend observed for methane energy, the $\mathrm{C}$ losses in $\mathrm{CH}_{4}$ were significantly lower with $\mathrm{RB}$ than $\mathrm{O}(1.3 \mathrm{vs} .1 .7 \mathrm{~g} / \mathrm{kg}$ of $\mathrm{BW}^{0.75}$, respectively; $\left.\mathrm{SEM}=0.14\right)$ due to lower $\mathrm{CH}_{4}$ production with this diet (see Table 1.9). The $\mathrm{C}$ secreted into the milk was not significantly affected by 
treatment and the retention of $\mathrm{C}$ was positive $\left(1.5 \mathrm{~g} / \mathrm{kg}\right.$ of $\mathrm{BW}^{0.75}$, on average; SEM $=0.58$ ). The efficiency of milk $C$ output regards to $C$ ingested was $25 \%$, on average.

Goats of the two groups ingested similar amounts of $N(2.6 \mathrm{~g} / \mathrm{kg}$ of $\mathrm{BW}^{0.75}$, on average; $\mathrm{SEM}=0.18$ ), while in Table 1.6 we can observe numerical lower intake in RB compared with $\mathrm{O}$. No differences were found in $\mathrm{N}$ losses in feces, urine, milk and retention. The ratio between milk $\mathrm{N}$ output and $\mathrm{N}$ ingested presented an average value of 0.31 . We observed $\mathrm{N}$ retention around zero, and slightly negative $\mathrm{N}$ balance for RB (0.0 vs. $-0.2 \mathrm{~g} / \mathrm{kg}$ of $\mathrm{BW}^{0.75}$; SEM $=0.10$ ). Although some authors (Kebreab et al., 2010) indicate reduction in urinary $\mathrm{N}$ output in dairy cows when ME intake increases, in our study no differences were observed in ME intake and urinary $\mathrm{N}$, in spite of the lower DMI observed with RB diet. The negative $\mathrm{N}$ balance detected with $\mathrm{RB}$ is probably linked to a larger amount of $\mathrm{NH}_{3}-\mathrm{N}$ observed in the ruminal liquid, which would indicate an inefficient use of ruminal $\mathrm{NH}_{3}-\mathrm{N}$ for ruminal proteosynthesis (Casper et al., 1999) due to fat interference on microbial activity (Palmquist and Jenkins, 1980).

The values of $\mathrm{N}$ retained in the body were converted to grams of protein, and from this and the $\mathrm{C}$ balance value, grams of retention of fat were calculated. No differences were found between diets. As shown in Table 1.4, the energy balance was positive, so the $R_{\text {fat }}$ was positive as well (2.0 vs. 2.4 $\mathrm{g} / \mathrm{kg}$ of $\mathrm{BW}^{0.75}$, for $O$ and $\mathrm{RB}$ respectively; SEM $=0.33$ ) and hence no fat mobilization was observed. The negative $R_{\text {protein }}$ in diet $R B\left(-1.0 \mathrm{~g} / \mathrm{kg}\right.$ of $\left.B W^{0.75}\right)$ was showed previously (Van Knegsel et al., 2007).

\subsubsection{Milk Production, Fatty Acid and Metabolites}

Table 1.7 reports milk yield and milk metabolites of the goats during the experiment. Diet had no effect on milk yield; average milk yield was 2,196.4 \pm $125.0 \mathrm{~g} / \mathrm{d}$. Chilliard et al. (2003) observed that fat supplementation increases milk yield in dairy cows but not in goats and, increased milk goat fat content but not always in dairy cows. The replacement of oat (cereal grain with high fiber content) with rice bran (fibrous byproduct with less fiber content than oat) made diet $\mathrm{O}$ greater in fiber than RB. Increased milk fat content is common when 
dietary fiber concentrations increase at the expense of starch, but in our study fat milk content was high in RB compared with $\mathrm{O}$ diet. Bypass fat added seems to be responsible for the significant differences $(p<0.01)$ in milk dry matter $(14.9 \%$ and $16.4 \%$, for $O$ and $R B$ respectively; $S E M=0.39$ ) and milk fat content $(5.3 \%$ and $6.9 \%$, for $\mathrm{O}$ and $\mathrm{RB}$ respectively; $\mathrm{SEM}=0.36)$. Further, in all studies revised by Chilliard et al. (2003) milk fat content increases with almost all studied fat supplements in goats but not in cows because their lipolytic systems differ. Milk protein content and lactose were not statistically different among treatments $(4.0 \%$ [SEM $=0.12$ ] and $4.8 \%$ [SEM $=0.08])$, on average for protein and lactose respectively). And again is observed that fat supplementation decreases milk protein content in dairy cows but not in goats.

Analysis of milk metabolites indicate that the 2 diets provided goats with enough energy for their production levels; consequently, the values of the energy indicators (BHBA and citrate with average values of $54.7 \mathrm{mM} / \mathrm{L}$ [SEM = 2.92] and $0.08 \mathrm{mM} / \mathrm{L}$ [SEM $=0.004]$, respectively) were in the normal range, consistent with those obtained by others authors (Bjerre-HarpØth et al., 2012). Glucose is the main precursor for lactose synthesis in the mammary gland (Linzell, 1968), and higher $(p<0.05)$ value was found for $O$ than $R B(0.17 \mathrm{mM} / \mathrm{L}$ vs. $0.13 \mathrm{mM} / \mathrm{L}$, respectively; $\mathrm{SEM}=0.010$ ).

Palmquist and Jenkins, (1980) showed reduction in blood glucose and insulin when protected lipids supplement replaced concentrate. No differences were observed in the potential biomarkers in milk or indicators of rumen $\mathrm{N}$ flow, such as uric acid and urea in milk $(49.6 \mu \mathrm{M} / \mathrm{L}$ [SEM $=7.64]$ and $2.6 \mathrm{mM} / \mathrm{L}[\mathrm{SEM}$ $=0.12$ ] on average, respectively).

Effect of diet on the fatty acid profile of milk fat are shown in Table 1.8. Compared with cow milk, goat milk is higher in medium chain fatty acids (caprylic acid and more markedly capric acid). Medium chain fatty acids contents were higher $(p<0.05)$ in $O$ compared to RB diet: capric acid, undecanoic acid, myristic acid, miristoleic acid and pentadecanoic acid. Undecanoic acid and pentadecanoic acid are potential biomarkers of rumen function since they are found in rumen bacterial lipids and might be partially 
synthesized endogenously from rumen substrates in the mammary gland (Vlaeminck et al., 2006, Fievez et al., 2012 and Vlaeminck et al., 2015).

The differences between treatments (lower contents of those fatty acids in the milk of RB goats) suggest a negative impact of RB oil on rumen bacterial metabolism, both de novo synthesis of bacterial lipids and the fermentative activity. Our ammonia- $\mathrm{N}$ results found in rumen liquid are in accordance with the differences observed in these fatty acids. Higher values $(p<0.05)$ were found in oleic acid and arachidic acid in RB compared with $\mathrm{O}$. Thus, significant differences were found in medium chain fatty acids (17.17 vs. $12.90 \mathrm{~g} / 100 \mathrm{~g}$ for $O$ and $R B$, respectively; SEM $=0.969$ ), and for monounsaturated fatty acids (20.63 vs. $28.29 \mathrm{~g} / 100 \mathrm{~g}$ for $\mathrm{O}$ and $\mathrm{RB}$, respectively; $\mathrm{SEM}=1.973$ ). No significant differences between diets for CLA were found. Hence, milk from goats fed RB diet was the highest in monounsaturated fatty acids and goats fed $\mathrm{O}$ diet had milk with more medium chain fatty acids. The fatty acids with 16 or fewer carbon atoms derive from de novo synthesis, whereas those with 18 or more carbons atoms come from the diet or from lipid mobilization (Chilliard et al., 2003). In the present experiment, under positive energy balance, recovered energy in tissue was positive (Table 1.4) and retained fat was positive (Table 1.6). Atherogenicity index (calculated as $\mathrm{C} 12: 0+4 \times \mathrm{C} 14: 0+$ C16:0/unsaturated fatty acids) was calculated as indicate by Ulbricht and Southgate (1991). The milk of goats fed RB diet has the lower atherogenicity index than $\mathrm{O}$ diet (2.17 vs. 3.50 on average, respectively; $\mathrm{SEM}=0.248$ ).

\subsubsection{Methane Emissions}

The effects of diet on $\mathrm{CH}_{4}$ emissions are shown in Table 1.9. Goats fed RB diet produced significantly $(p<0.05)$ less $\mathrm{CH}_{4}$ emissions $(23.2 \mathrm{~g} / \mathrm{d})$ than $\mathrm{O}$ diet $(30.1 \mathrm{~g} / \mathrm{d})$, with a SEM $=2.14$. The inhibition of $\mathrm{CH}_{4}$ production is normally accompanied by an increase in propionate production, which uses hydrogen and lactic acid. Cao et al. (2010) fed sheep fermented (high in lactic acid) and non-fermented total mixed ration containing whole crop rice and rice bran, although the fermented mixed ration increased the digestibility, decreased ruminal $\mathrm{CH}_{4}$ emission from 28.3 to $21.2 \mathrm{~g} / \mathrm{d}$ as a result of the conversion lactic acid to propionic acid in the rumen. 
According to Johnson and Johnson (1995), fermentation of fibrous carbohydrates produces more $\mathrm{CH}_{4}$ than fermentation of soluble sugars, which in turn produce more $\mathrm{CH}_{4}$ than fermentation of starch. As discussed previously, structural carbohydrates, NFC and starch were lower in RB than O diet (5.6 point lower for NDF, NFC and starch, on average), and the main difference was the higher lipid content in $\mathrm{RB}$ diet $(11.7 \%$ vs. $4.1 \%$ for $\mathrm{RB}$ and $\mathrm{O}$ diets, respectively). Fat content on $\mathrm{RB}$ diet explain the $\mathrm{CH}_{4}$ mitigation observed in this diet. Diets with lipids added are one of the ways to lowering enteric $\mathrm{CH}_{4}$ emissions by ruminants (Knapp et al., 2014). Increasing the lipid content of the diet is acknowledged as a $\mathrm{CH}_{4}$ mitigation strategy due to reduction of methanogenesis and the biohydrogenation of unsaturated fatty acids (alternative sink of $\mathrm{H}_{2}$ ). Moreover, $\mathrm{CH}_{4}$ output was positively correlated to milk C6:0 to C16:0 (Fievez et al. 2012), which result mainly from mammary de novo fatty acids synthesis, based primarily on the use of acetate produced in the rumen during fiber digestion and being, these milk fatty acids contents, lower in RB diet (Table 1.8).

Methane conversion ratio, also called $Y m$ factor, represents energy loss as $\mathrm{CH}_{4}$ per unit of $\mathrm{GE}$ intake. The $\mathrm{Ym}$ for both diets was $4.7 \%$, on average (SEM $=0.47$ ). Although $\mathrm{CH}_{4}$ emission is most commonly expressed in the literature relative to $\mathrm{GE}$ intake, the most meaningful expression is relative to intake or $\mathrm{OM}$. In the present work, the $\mathrm{CH}_{4}$ production related to $\mathrm{DMI}$, digested OM, digested NDF or kg of milk produced was no significant.

\subsection{Conclusions}

The total replacement of oat grain with rice bran (higher in lipids content than oat grain) reduced DMI by a $12 \%$ without effect on milk yield $(2.2 \mathrm{~kg} / \mathrm{d}$, on average) in Murciano-Granadina goats during late lactation. This was accompanied by differences in ammonia nitrogen concentration in the rumen liquor, and might suggest partial inhibition of microbial synthesis by the rice bran fat. The differences found between treatments (lower contents of undecanoic acid and pentadecanoic acid in the goat milk fed rice bran) suggest a negative impact of rice bran oil on rumen bacterial metabolism, both de novo synthesis of bacterial lipids and the fermentative activity. Also, we observed reduction of enteric $\mathrm{CH}_{4}$ emission of $6.9 \mathrm{~g} / \mathrm{d}$ for diet that incorporated rice bran. Milk fat 
content and monounsaturated fatty acids increase when rice bran was incorporated to the diet, so lactating goats could utilize rice bran diets without detrimental effect on milk performance. More studies evaluating rice bran without any bypass fat added should be noteworthy.

\subsection{Acknowledgements}

This study was supported by INIA Project, Spain (ref. RTA2014-00046C02-02). 


\subsection{References}

Agricultural and Food Research Council (AFRC). 1993. Energy and protein requirements of ruminants. CAB International, Wallingford, UK.

Aguilera, J. F., and C. Prieto. 1986. Description and function of an open-circuit respiration plant for pigs and small ruminants and the techniques used to measure energy metabolism. Arch. Anim. Nutr. 11:1009-1018.

Aguilera, J. F., C. Prieto, and J. Fonollá. 1990. Protein and energy metabolism of lactating Granadina goats. Br. J. Nutr. 63:165-175.

AOAC International. 2000. Official Methods of Analysis of the Association of Official Analytical Chemists, $18^{\text {th }}$ ed. Association of Official Analytical Chemists, Arlington, VA, USA.

Batey, I. L. 1982. Starch analysis using thermostable alpha-amylases. Stach/Stärke. 34:125-128.

Bava, L., L. Rapetti, G. M. Crovetto, A. Tamburini, A. Sandrucci, G. Galassi, and G. Succi. 2001. Effect of a non-forage diet on milk production, energy and nitrogen metabolism in dairy goats throughout lactation. J. Dairy Sci. 84:2450-2459.

Bjerre-HarpØth, V., N. C. Friggens, V.M. Thorup, T. Larsen, B. M. Damgaard, K. L. Ingvartsen, and K. M. Moyes. 2012. Metabolic and production profiles of dairy cows in response to decreased nutrient density to increase physiological imbalance at different stages of lactation. J. Dairy Sci. 95:2362-2380.

Brockway, J. M., A. W. Boyne, and J. G. Gordon. 1971. Simultaneous calibration of gas analyzers and meters. J. Appl. Physiol. 31:296-297.

Brouwer, E. 1958. On simple formulae for calculating the heat expenditure and the quantities of carbohydrate and fat metabolized in ruminants, from data on gaseous exchange and urine N. Pages 182-194 in Proc. $1^{\text {th }}$ Symposium on Energy Metabolism. EAAP. Publ. 8. Academic Press, London.

Brouwer, E. 1965. Report of sub-committee on constants and factors. In: Blaxter, K.L. (Ed.), Pages 441-443 in Proc. of the $3^{\text {th }}$ Symposium on Energy Metabolism. EAAP. Publ. 11. Academic Press, London. 
Calsamiglia, S., A. Bach, C. de Blas, C. Fernández, and P. García-Rebollar. 2009. Nutritional requirements for dairy ruminants. Fundación Española para el Desarrollo de la Nutrición Animal (FEDNA). Madrid, Spain.

Cao, Y., T. Takahashi, K. Horiguchi, N. Yoshida, and Y. Cai. 2010. Methane emissions from sheep fed fermented or non fermented total mixed ration containing whole-crop rice and rice bran. Anim. Feed Sci. Technol. 157:7278.

Casper, D. P., H. A. Maiga, M. J. Brouk, and D. J. Schingoethe. 1999. Synchronization of carbohydrate and protein sources on fermentation and passage rates in dairy cows. J. Dairy Sci. 28:1779-1790.

Chilliard, Y., A. Ferlay, J. Rouel, and G. Lamberet. 2003. A review and nutritional and physiological factors affecting goat milk lipids synthesis and lipolysis. J. Dairy Sci. 86:1751-1770.

Chwalibog, A., A. H. Tauson, and G. Thorbek. 1997. Quantitative oxidation of nutrients in growing calves. Z. Ernährungswiss. 36:313-316.

Elliot, R., H. M. Ferreiro, A. Priego, and T.R. Preston. 1978. Estimate of the quantity of feed protein escaping degradation in rumen of steers fed chopped sugar cane, malasses/urea supplemented with varying quantities of rice polishing. Trop. Anim. Prod. 3:36-39.

European Union. 2003. Protection of animals used for experimental purposes. Council Directive 86/609/EEC of 24 November 1986, amended 16.9.2003. European Council, Brussels, Belgium.

Fahey, G. C., and L. L. Berger. 1988. Carbohydrate nutrition of ruminants. Pages 269-297 in Church, D.C. (Ed.), The Ruminant Animal. Digestive Nutrition and Physiology. Prentice-Hall, Englewood Cliffs, NJ.

FEDNA, 2010. Fundación Española para el Desarrollo de la Nutrición Animal. Tablas de composición y valor nutritivo de alimentos para la fabricación de piensos compuestos. $3^{\text {rd }}$ ed. Fundación Española Desarrollo Nutrición Animal, Madrid, Spain.

Fernández, C., M. C. López, and M. Lachica. 2012. Description and function of a mobile open-circuit respirometry system to measure gas exchange in small ruminants. Anim. Feed Sci. Technol. 172:242-246. 
Fernández, C., M. C. López, and M. Lachica. 2015. Low cost open-circuit hood system for measuring gs exchange in small ruminants: from manual to automatic recording. J. Agri. Sci. 153:1302-1309.

Fievez, V., E. Colman, J. M. Castro-Montolla, I. Stefanov and, B. Vlaeminck. 2012. Milk odd- and branched-chain fatty acids as biomarkers of rumen function-An update. Anim. Feed Sci. Technol. 172:51-65.

Forster, L. A., A. L. Goetsch, D. L. Galloway, W. Sun, A.R. Patil, and Z.B. Johnson. 1994. Digestion characteristics feed intake and live weight gain by cattle consuming forage supplemented with deffated rice bran or other feedstuffs. Anim. Feed Sci. Technol. 47:259-275.

Johnson, K. A., and D. E. Johnson. 1995. Methane emissions in cattle. J. Anim. Sci. 73:2483-2492.

Jouany, J. P. 1982. Volatile fatty acid and alcohol determination in digestive contents, silage juices, bacterial cultures and anaerobic fermentor contents. Sci. Aliments. 2:131-144.

Kebreab, E., A. B. Strathe, J. Dijkstra, J. A. N. Mills, C. K. Reynolds, L. A. Crompton, T. Yan, and J. France. 2010. Energy and protein interactions and their effects on nitrogen excretion in dairy cows. Pages 417-426 in Symp. on Energy and Protein Metabolism and Nutrition, Parma, Italy,

Knapp, J. R., G. L. Laur, P. A. Vadas, W .P. Weis, and J.M. Tricarico. 2014. Invited review: Enteric methane in dairy cattle production: Quantifying the opportunities and impact of reducing emissions. J. Dairy Sci. 97:3231-3261.

Lachica, M., and J. F. Aguilera. 2003. Estimation of energy needs in the freeranging goat with particular reference to the assessment of its energy expenditure by the ${ }^{13} \mathrm{C}$-bicarbonate method. Small Rum. Res. 49:303-318.

Larsen, T., and K. M. Moyes. 2010. Fluorometric determination of uric acid in bovine milk. J. Dairy Res. 77:438-444.

Larsen, T., and N. I. Nielsen. 2005. Fluorometric determination of Bhydroxybutyrate in milk and blood plasma. J. Dairy Sci. 88:2004-2009.

Linzell, J. L. 1968. The magnitude and mechanisms of the uptake of milk precursosrs by the mammary gland. Proc. Nutr. Soc. 27:44-52

López, M. C., F. Estellés, V. J. Moya, and C. Fernández. 2014. Use of dry citrus pulp or soybean hulls as a replacement for corn grain in energy and 
nitrogen partitioning, methane emissions, and milk performance in lactating Murciano-Granadina goats. J. Dairy Sci. 97:7821-7832.

Lunsin, R., M. Wanapat, C. Yuangklang, and P. Rowlinson. 2012. Effect of rice bran oil supplementation on rumen fermentation, milk yield and milk composition in lactating dairy cows. Livest. Sci. 145:167-173.

McLean, J. A., and G. Tobin. 1987. Animal and Human Calorimetry. Cambridge University Press, Cambridge.

Mertens, D. R. 2002. Gravimetric determination of amylase-treated neutral detergent fibre in feeds with refluxing beakers or crucibles: collaborative study. J. AOAC Int. 85:1217-1240.

Moraes, L.E., E. Kebreab, A.B. Strathe, J. Dijkstra, J. France, D.P. Casper and J.G. Fadel. 2015. Multivariate and univariate analysis of energy balance data from lactating dairy cows. J. Dairy Sci. 98: 4012-4029.

National Research Council (NRC). 2001. Nutrient requirements of dairy cattle. 7th rev. ed. Natl. Acad. Press, Washington, D.C.

O’Fallon, J.V., J. R. Busboom, M. L. Nelson, and C.T. Gaskins. 2007. A direct method for fatty acid methyl ester synthesis: Application to wet meat tissues, oils, and feedstuffs. J. Anim. Sci. 85: 1511-1521.

Oliveira, M.S., V. Feddern, L. Kupski, E. P. Cipolatti, E. Badiale-Furlong, and L. A. Souza-Soares. 2011. Changes in lipid, fatty acids and phospholipids composition of whole rice bran after solid-stage fungal fermentation. Bioresour. Technol. 102: 8335-8338.

Ørskov, E. R., and C. Fraser. 1975. The effects of processing of barley -based supplements on rumen $\mathrm{pH}$, rate of digestion and voluntary intake of dried grass in sheep. Br. J. Nutr. 34:493-500.

Palmquist, D.L., and T.C., Jenkins. 1980. Fat in lactation rations: Review. J. Dairy Sci. 63:1-14.

Romero-Huelva, M., E. Ramos-Morales, and E. Molina-Alcaide. 2012. Nutrient utilization, ruminal fermentation, microbial abundances, and milk yield and composition in dairy goats fed diets including tomato and cucumber waste fruits. J. Dairy Sci. 95:6015-6026.

SAS (Statistical Analysis System). 2001. User's Guide, Version 8.02, Statistical Analysis System Institute Inc. Cary, NC, USA. 
Tovar-Luna, I., R. Puchala, T. Sahlu, H. C. Freetly, and A. L. Goetsch. 2010. Effects of stage of lactation and dietary concentrate level on energy utilization by Alpine dairy goats. J. Dairy Sci. 93:4818-4828.

Ulbricht, T.L., and DA. T. Southgate. 1991. Coronary Heart Disease: Seven Dietary Factors. Lancet, 338:985-992.

Van Soest, P. J. 2006. Rice straw, the role of silica and treatments to improve quality. Anim. Feed Sci. Technol. 130:137-171.

Vlaeminck, B., V. Fievez, A.R.J. Cabrita, A.J.M. Fonseca, and R.J. Dewhurst. 2006. Factors affecting odd-and branched-chain fatty acids in milk: $A$ review. Anim. Feed Sci. Technol. 131:389-417.

Vlaeminck, B., R. Gervais, M. M. Rahman, F. Gadeyne, M. Gorniak, M. Doreau, and V. Fievez. 2015. Postruminal synthesis modifies the odd- and branched-chain fatty acid profile from the duodenum to milk. J. Dairy Sci. 98:4829-4840.

Warren, B.E., and D.J. Farrell. 1990. The nutritive value of full fat and defatted Australian rice bran. I. Chemical composition. Anim. Feed Sci. Technol. 27:219-228.

Zhao, Y., K. Taniguchi, and T. Obitsu. 1996. Effects of different processing procedures for rice bran on dietary nutrient digestion in each segment of the digestive tract of steers. Anim. Feed Sci. Technol. 59:265-277. 
Table 1.1. Ingredients and chemical composition of the mixed diets diets.

\begin{tabular}{lcccc}
\hline & & & \multicolumn{2}{c}{ Diet $^{1}$} \\
\hline Item & & & \\
Ingredients, g/kg of dry matter & & rice bran & $\mathrm{O}$ & $\mathrm{RB}$ \\
Alfalfa hay & & & 350 & 350 \\
Oats & 1000 & & 379 & \\
Rice bran & & 1000 & & 379 \\
Barley & & & 182 & 197 \\
Soy meal (44\% CP) & & & 64 & 29 \\
Bypass fat & & & 15 & 33 \\
Calcium carbonate & & & 3.3 & 3.3 \\
Sodium chloride & & & 1.2 & 4.1 \\
Premix & & & 5.4 & 5.4 \\
Chemical composition, \% of DM & & & & \\
DM & $90.0 \pm 5.4$ & $89.7 \pm 3.6$ & 88.8 & 89.1 \\
ash & $2.9 \pm 0.2$ & $8.2 \pm 0.4$ & 7.9 & 9.7 \\
OM & & & 92.1 & 90.3 \\
CP & $8.4 \pm 0.4$ & $13.8 \pm 0.8$ & 15.3 & 16.1 \\
Ether extract & $4.9 \pm 0.3$ & $13.9 \pm 0.8$ & 4.1 & 11.7 \\
NDF & $31.2 \pm 1.9$ & $17.9 \pm 0.9$ & 27.2 & 22.8 \\
ADF & $17.1 \pm 0.5$ & $9.1 \pm 0.4$ & 12.4 & 10.4 \\
NFC & & & 45.5 & 39.8 \\
Starch & $37.0 \pm 1.9$ & $27.1 \pm 1.4$ & 28.2 & 21.6 \\
Carbon & & & 43.5 & 44.6 \\
GE, MJ/kg of DM & & & 17.9 & 19.4 \\
\hline & & & &
\end{tabular}

${ }^{1} \mathrm{O}=$ oats; $\mathrm{RB}=$ rice bran.

${ }^{2}$ Bypass fat of palm fatty acid distillate. Provided by Norel Animal Nutrition, Norel S.A., Spain. Premix = Provided by NACOOP S.A. España. Premix composition $(\mathrm{mg} / \mathrm{kg}$ or UI per kilogram of premix): Se, 40; I, 250; Co, 80; Cu, 3000; Fe, 6000; Zn, 23400; Mn, 29000; S, 60000; Mg, 60000; vitamin A, 2000000 Ul; vitamin D3, 400000; vitamin E, 2000 ppm; nicotinic acid, 10000; choline, 20300. NFC = non fibrous carbohydrate content: $100-(N D F+a s h+C P+E E) . G E=$ gross energy. 
Table 1.2. Body weight, intake, and apparent digestibility coefficients of Murciano-Granadina goats $(n=10)$ during late lactation according to the type of diet.

\begin{tabular}{lcccc}
\hline & \multicolumn{2}{c}{ Diet $^{1}$} & & P-value \\
\hline Item \\
\end{tabular}

${ }^{1} \mathrm{O}=$ oats; $\mathrm{RB}=$ rice bran.

${ }^{2} \mathrm{DM}=$ dry matter; $\mathrm{OM}=$ organic matter; $\mathrm{CP}=$ crude protein; $\mathrm{EE}=$ ether extract; NDF = neutral detergent fiber; $A D F=$ acid detergent fiber; $G E$ = gross energy. 
Table 1.3. $\mathrm{pH}$, ammonia- $\mathrm{N}\left(\mathrm{NH}_{3}-\mathrm{N}\right)$, and VFA of Murciano-Granadina goats $(\mathrm{n}=$ 10) during late lactation according to the type of diet.

\begin{tabular}{lcccc}
\hline & \multicolumn{2}{c}{ Diet $^{1}$} & & P-value \\
\hline Item $^{2}$ & $\mathrm{O}$ & $\mathrm{RB}$ & $\mathrm{SEM}$ & Diet \\
\hline $\mathrm{pH}$ & 7.3 & 7.0 & 0.08 & 0.03 \\
$\mathrm{NH}_{3}$-N, mg/dL & 15.8 & 23.3 & 2.00 & 0.05 \\
Total VFA, mmol/L & 21.5 & 19.6 & 1.83 & 0.64 \\
Individual VFA, mol/100 mol & & & & \\
Acetic acid & 61.6 & 56.7 & 2.11 & 0.28 \\
Propionic acid & 15.0 & 19.1 & 1.47 & 0.18 \\
Isobutyric acid & 3.3 & 3.0 & 0.48 & 0.85 \\
Butyric acid & 13.0 & 14.0 & 0.85 & 0.63 \\
Isovaleric acid & 3.7 & 3.4 & 0.44 & 0.78 \\
n-Valeric acid & 2.3 & 2.5 & 0.39 & 0.84 \\
n-Caproic acid & 0.8 & 0.8 & 0.25 & 0.90 \\
Heptanoic acid & 0.5 & 0.5 & 0.18 & 0.92 \\
\hline
\end{tabular}

${ }^{1} \mathrm{O}=$ oats; $\mathrm{RB}=$ rice bran.

${ }^{2} \mathrm{NH}_{3}-\mathrm{N}=$ ammonia nitrogen. 
Table 1.4. Daily energy partitioning $\left(\mathrm{kJ} / \mathrm{kg}\right.$ of $\left.\mathrm{BW}^{0.75}\right)$ of Murciano-Granadina goats $(n=10)$ during late lactation according to the type of diet.

\begin{tabular}{lcccc}
\hline & \multicolumn{2}{c}{ Diet $^{1}$} & & P-value \\
\hline Item $^{2}$ & $\mathrm{O}$ & RB & SEM & Diet \\
\hline GEI & 1,889 & 1,777 & 137.1 & 0.71 \\
$\mathrm{E}_{\text {feces }}$ & 504 & 396 & 35.8 & 0.04 \\
$\mathrm{E}_{\text {urine }}$ & 41 & 50 & 4.9 & 0.41 \\
$\mathrm{E}_{\text {methane }}$ & 95 & 73 & 7.6 & 0.04 \\
MEI & 1,2 & 1,3 & 110.0 & 0.97 \\
$\mathrm{HP}$ & 651 & 628 & 21.0 & 0.62 \\
$\mathrm{E}_{\text {milk }}$ & 491 & 524 & 36.0 & 0.67 \\
$\mathrm{RE}_{\text {body }}$ & 107 & 106 & 68.4 & 1.00 \\
\hline
\end{tabular}

${ }^{1} \mathrm{O}=$ oats; $\mathrm{RB}=$ rice bran.

${ }^{2} \mathrm{GEI}=$ gross energy intake; $\mathrm{E}_{\text {feces }}=$ energy losses in feces; $\mathrm{E}_{\text {urine }}=$ energy losses in urine; $\mathrm{E}_{\text {methane }}=$ energy losses in methane; $\mathrm{MEI}=$ metabolizable energy intake; $\mathrm{HP}=$ heat production; $\mathrm{RE}_{\text {total }}=$ total recovered energy; $\mathrm{E}_{\text {milk }}=$ recovered energy in milk; $R E_{\text {body }}=$ recovered energy in tissue (REbody $=\mathrm{MEI}-\mathrm{HP}-$ Emilk). 
Table 1.5. Heat production $\left(\mathrm{kJ} / \mathrm{kg}\right.$ of $\left.\mathrm{BW}^{0.75}\right)$ from oxidation and fermentation; daily oxidation $\left(\mathrm{kJ} / \mathrm{kg}\right.$ of $\left.\mathrm{BW}^{0.75}\right)$ of protein, carbohydrate, and fat; and their contribution to the heat production from oxidation substrates (\%) of MurcianoGranadina goats $(n=10)$ during late lactation according to the type of diet.

\begin{tabular}{lcccc}
\hline & \multicolumn{2}{c}{ Diet $^{1}$} & & P-value \\
\hline Item $^{2}$ & $\mathrm{O}$ & $\mathrm{RB}$ & SEM & Diet \\
\hline $\mathrm{HPx}$ & 632 & 614 & 20.2 & 0.68 \\
$\mathrm{HPf}$ & 19 & 15 & 1.5 & 0.16 \\
OXP & 119 & 126 & 6.2 & 0.62 \\
OXCHO & 211 & 100 & 29.6 & 0.05 \\
OXF & 302 & 388 & 24.1 & 0.07 \\
OXP/HPx & 19 & 21 & 1.2 & 0.49 \\
OXCHO/HPx & 33 & 15 & 4.5 & 0.04 \\
OXF/HPx & 48 & 64 & 4.3 & 0.06 \\
RQnpx & 0.83 & 0.77 & 0.015 & 0.04 \\
\hline
\end{tabular}

${ }^{1} \mathrm{O}=$ oats; $\mathrm{RB}=$ rice bran.

${ }^{2} \mathrm{HPx}=$ heat production from oxidation of nutrients; $\mathrm{HPf}=$ heat production of fermentation [HPf = HP - HPx (Brouwer, 1958)]; OXP = heat production associated with the oxidation of protein; $\mathrm{OXCHO}=$ heat production associated with the oxidation of carbohydrates; OXF = heat production associated with the oxidation of fat; $\mathrm{RQnpx}=$ nonprotein respiratory quotient (unitless) from oxidation of nutrients $\left\{\left[\mathrm{CO}_{2} \mathrm{X}-(\mathrm{N}\right.\right.$ urine $\times$ $6.25 \times 0.774)]\left[\mathrm{O}_{2}-(\mathrm{N}\right.$ urine $\left.\times 6.25 \times 0.957)\right]$, where $\mathrm{CO}_{2}=\mathrm{CO}_{2}$ production from oxidation and Nurine $=\mathrm{N}$ in urine $\}$. 
Table 1.6. Carbon and nitrogen balance $\left(\mathrm{g} / \mathrm{kg}\right.$ of $\left.\mathrm{BW}^{0.75}\right)$ of Murciano-Granadina goats $(n=10)$ during late lactation according to the type of diet.

\begin{tabular}{lcccc}
\hline & \multicolumn{2}{c}{ Diet $^{1}$} & & $P$-value \\
\hline Item $^{2}$ & $\mathrm{O}$ & $\mathrm{RB}$ & $\mathrm{SEM}$ & Diet \\
\hline $\mathrm{C}_{\text {intake }}$ & 45.7 & 40.8 & 3.26 & 0.49 \\
$\mathrm{C}_{\text {feces }}$ & 14.0 & 10.6 & 1.09 & 0.13 \\
$\mathrm{C}_{\text {urine }}$ & 1.3 & 1.5 & 0.08 & 0.18 \\
$\mathrm{C}_{\mathrm{CO} 2}$ & 16.4 & 14.8 & 0.66 & 0.25 \\
$\mathrm{C}_{\mathrm{CH} 4}$ & 1.7 & 1.3 & 0.14 & 0.04 \\
$\mathrm{C}_{\text {milk }}$ & 10.6 & 11.2 & 0.76 & 0.73 \\
$\mathrm{C}_{\text {retained body }}$ & 1.7 & 1.4 & 0.58 & 0.93 \\
$\mathrm{~N}_{\text {intake }}$ & 2.6 & 2.4 & 0.18 & 0.58 \\
$\mathrm{~N}_{\text {feces }}$ & 0.7 & 0.7 & 0.06 & 0.61 \\
$\mathrm{~N}_{\text {urine }}$ & 1.0 & 1.1 & 0.05 & 0.62 \\
$\mathrm{~N}_{\text {milk }}$ & 0.8 & 0.8 & 0.04 & 0.75 \\
$\mathrm{~N}_{\text {retained body }}$ & 0.0 & -0.2 & 0.10 & 0.38 \\
$\mathrm{R}_{\text {protein }}$ & 0.2 & -1.0 & 0.44 & 0.41 \\
$\mathrm{R}_{\text {fat }}$ & 2.0 & 2.4 & 0.33 & 0.88 \\
\hline
\end{tabular}

${ }^{1} \mathrm{O}=$ oats; $\mathrm{RB}=$ rice bran.

${ }^{2} \mathrm{C}_{\text {intake }}=\mathrm{C}$ intake; $\mathrm{C}_{\text {feces }}=\mathrm{C}$ losses in feces; $\mathrm{C}_{\text {urine }}=\mathrm{C}$ losses in urine; $\mathrm{C}_{\mathrm{CO} 2}=\mathrm{C}$ losses in $\mathrm{CO}_{2} ; \mathrm{C}_{\mathrm{CH} 4}=\mathrm{C}$ losses in methane; $\mathrm{C}_{\text {milk }}=$ recovered $\mathrm{C}$ in milk; $\mathrm{C}_{\text {retained body }}=$ recovered $C$ in tissue $; N_{\text {intake }}=N$ intake; $N_{\text {feces }}=N$ losses in feces; $N_{\text {urine }}=N$ losses in urine; $N_{\text {milk }}=$ recovered $\mathrm{N}$ in milk; $N_{\text {retained body }}=$ recovered $\mathrm{N}$ in tissue; $R_{\text {protein }}=$ retained protein; $R_{\text {fat }}=$ retained fat. 
Table 1.7. Daily milk production, composition and metabolites of MurcianoGranadina goats $(n=10)$ during late lactation according to the type of diet.

\begin{tabular}{lcccc}
\hline \multicolumn{2}{c}{ Diet $^{1}$} & & $P$-value \\
\hline Item $^{2}$ & $\mathrm{O}$ & $\mathrm{RB}$ & $\mathrm{SEM}$ & Diet \\
\hline Milk production, g/d & $2,244.5$ & $2,148.2$ & 125.03 & 0.73 \\
Composition, \% & & & & \\
DM & 14.9 & 16.4 & 0.39 & 0.04 \\
Fat & 5.3 & 6.9 & 0.36 & 0.01 \\
Protein & 4.0 & 4.1 & 0.12 & 0.91 \\
Lactose & 4.9 & 4.7 & 0.08 & 0.30 \\
Milk metabolites & & & & \\
BHBA, $\mu \mathrm{M} / \mathrm{L}$ & 55.3 & 54.0 & 2.92 & 0.83 \\
Glucose, $\mathrm{mM} / \mathrm{L}$ & 0.17 & 0.13 & 0.010 & 0.05 \\
Glucose $6 \mathrm{P}, \mathrm{mM} / \mathrm{L}$ & 0.14 & 0.10 & 0.010 & 0.02 \\
isoCitrate, $\mathrm{mM} / \mathrm{L}$ & 0.08 & 0.08 & 0.004 & 0.38 \\
Uric acid, $\mu \mathrm{M} / \mathrm{L}$ & 40.5 & 58.4 & 7.64 & 0.27 \\
Milk urea, $\mathrm{mM} / \mathrm{L}$ & 2.8 & 2.4 & 0.12 & 0.06 \\
\hline
\end{tabular}

${ }^{1} \mathrm{O}=$ oats; $\mathrm{RB}=$ rice bran.

${ }^{2}$ BHBA $=$ ß-hydroxybutyrate, Glucose 6P $=$ Glucose 6 Phosphate 
Table 1.8. Fatty acid composition ( $\mathrm{g} / 100 \mathrm{~g}$ of identified fatty acids) of milk fat for Murciano-Granadina goats $(n=10)$ during late lactation according to the type of diet

\begin{tabular}{|c|c|c|c|c|}
\hline & \multicolumn{2}{|c|}{$\operatorname{Diet}^{1}$} & \multicolumn{2}{|r|}{$P$-value } \\
\hline $\mathrm{Item}^{2}$ & $\mathrm{O}$ & $\mathrm{RB}$ & SEM & Diet \\
\hline $\mathrm{C} 4: 0$ & 0.33 & 0.34 & 0.023 & 0.893 \\
\hline C6:0 & 1.06 & 0.97 & 0.072 & 0.570 \\
\hline C8:0 & 1.99 & 1.68 & 0.139 & 0.297 \\
\hline C10:0 & 9.61 & 6.81 & 0.680 & 0.027 \\
\hline C11:0 & 0.30 & 0.21 & 0.021 & 0.034 \\
\hline C12:0 & 4.20 & 3.23 & 0.593 & 0.452 \\
\hline C14:0 & 10.57 & 7.76 & 0.597 & 0.006 \\
\hline C14:1 & 0.17 & 0.12 & 0.010 & 0.004 \\
\hline C15:0 & 0.11 & 0.08 & 0.008 & 0.002 \\
\hline C16:0 & 37.81 & 34.63 & 1.866 & 0.434 \\
\hline C16:1 & 0.92 & 0.91 & 0.050 & 0.948 \\
\hline C17:0 & 0.53 & 0.48 & 0.053 & 0.677 \\
\hline C17:1 & 0.21 & 0.23 & 0.035 & 0.738 \\
\hline C18:0 & 9.70 & 14.25 & 1.278 & 0.072 \\
\hline C18:1n9t & 1.40 & 0.27 & 0.316 & 0.070 \\
\hline C18:1n9c & 19.38 & 27.15 & 1.957 & 0.037 \\
\hline C18:1n7 & 0.37 & 0.35 & 0.031 & 0.810 \\
\hline C18:2n6c & 3.21 & 3.30 & 0.189 & 0.815 \\
\hline C20:0 & 0.18 & 0.30 & 0.027 & 0.014 \\
\hline C18:3n6 & 0.01 & 0.00 & 0.004 & 0.731 \\
\hline C20:1 & 0.15 & 0.11 & 0.017 & 0.176 \\
\hline C18:3n3 & 0.32 & 0.28 & 0.017 & 0.284 \\
\hline CLA 9c11t + 9t11c & 0.70 & 1.19 & 0.156 & 0.124 \\
\hline CLA 10t12c & 0.02 & 0.01 & 0.002 & 0.093 \\
\hline C20:4n6 & 0.21 & 0.17 & 0.014 & 0.196 \\
\hline Medium-chain fatty acids & 17.17 & 12.90 & 0.969 & 0.015 \\
\hline Monounsaturated fatty acids & 20.63 & 28.29 & 1.973 & 0.043 \\
\hline Polyunsaturated fatty acids & 3.74 & 3.76 & 0.196 & 0.966 \\
\hline Saturated fatty acids & 75.46 & 69.96 & 3.579 & 0.483 \\
\hline Atherogenicity index & 3.50 & 2.17 & 0.248 & 0.001 \\
\hline
\end{tabular}

${ }^{1} \mathrm{O}=$ oats; $\mathrm{RB}=$ rice bran.

${ }^{2} \mathrm{CLA}=$ conjugated linoleic acid; Atherogenicity index calculated as C12:0 $+4 \times \mathrm{C} 14: 0$ + C16:0/unsaturated fatty acids (Ulbricht and Southgate, 1991). 
Table 1.9. Methane emission of Murciano-Granadina goats $(n=10)$ during late lactation according to the type of diet.

\begin{tabular}{|c|c|c|c|c|}
\hline \multirow[b]{2}{*}{ Item $^{2}$} & \multicolumn{2}{|c|}{$\operatorname{Diet}^{1}$} & \multicolumn{2}{|r|}{$P$-value } \\
\hline & $\mathrm{O}$ & $\mathrm{RB}$ & SEM & Diet \\
\hline $\mathrm{CH}_{4}, \mathrm{~g} / \mathrm{d}$ & 30.1 & 23.2 & 2.14 & 0.05 \\
\hline$Y m, \%$ & 5.2 & 4.3 & 0.47 & 0.39 \\
\hline $\mathrm{CH}_{4} / \mathrm{DMi}, \mathrm{g} / \mathrm{kg}$ & 16.7 & 15.0 & 1.52 & 0.61 \\
\hline $\mathrm{CH}_{4} / \mathrm{OMd}, \mathrm{g} / \mathrm{kg}$ & 25.6 & 21.8 & 2.59 & 0.50 \\
\hline $\mathrm{CH}_{4} / \mathrm{NDFd}, \mathrm{g} / \mathrm{kg}$ & 236.2 & 137.1 & 46.02 & 0.32 \\
\hline $\mathrm{CH}_{4} / \mathrm{milk}, \mathrm{g} / \mathrm{kg}$ & 13.6 & 11.1 & 1.16 & 0.31 \\
\hline
\end{tabular}

${ }^{1} \mathrm{O}=$ oats; $\mathrm{RB}=$ rice bran.

${ }^{2} \mathrm{Ym}=$ methane energy/gross energy intake; $\mathrm{DMi}=$ dry matter intake; OMd $=$ digested organic matter; NDFd = digested neutral detergent fiber. 

Replacement of alfalfa hay (Medicago sativa) with maralfalfa hay (Pennisetum sp.) in diets of lactating dairy goats 

Replacement of alfalfa hay (Medicago sativa) with maralfalfa hay (Pennisetum sp.) in diets of lactating dairy goats

P. Criscioni ${ }^{a}$, J.V. Marti ${ }^{b}$, I. Pérez-Baena ${ }^{b}$, J.L. Palomares ${ }^{b}$, T. Larsen ${ }^{c}$ and C. Fernández ${ }^{\mathrm{a}}$,

aACUMA Research Center. Polytechnic University of Valencia. 46022 Valencia. Spain.

${ }^{b}$ Animal Science Department. Polytechnic University of Valencia. 46022 Valencia. Spain.

'Department. of Animal Science, Aarhus University Blichers Allé 20, PO Box 50, 8830 Tjele, Denmark

*Corresponding author. Tel: +00 34963877 007; Fax: +00 34963877 439; Email address: cjfernandez@dca.upv.es 



\subsection{Abstract}

The objective of this experiment was to study the effects of substituting alfalfa (Medicago sativa) with maralfalfa (Pennisetum sp.) on energy, nitrogen and carbon balance, methane emission, and milk performance in dairy goats. Ten Murciano-Granadina dairy goats in late lactation $(45.7 \pm 2.96 \mathrm{~kg}$ of body weight [BW]) were selected in a 2 treatments and a crossover design experiment where each goat received both treatments in 2 periods. One group of five goats was fed a mixed ration with alfalfa as forage (A diet) and the other diet replaced alfalfa with maralfalfa ( $M$ diet) in a forage concentrate ratio 40/60. Diets were formulated to be isoenergetic and isoproteic. The goats were allocated to individual metabolism cages. After $17 \mathrm{~d}$ of adaptation, feed intake, total fecal and urine output and milk yield were recorded daily over a $5 \mathrm{~d}$ period. Then, gas exchange measurements were recorded individually by a mobile open-circuit indirect calorimetry system using a head box. Dry matter intake was different for both diets (1.8 vs. 1.6, for $A$ and $M$ respectively) but no differences was observed in metabolizable energy intake $(1,089 \mathrm{~kJ} / \mathrm{kg}$ of BW0.75, on average). Greater values in $\mathrm{M}$ than A were found in rumen propionic acid (17.5 vs. 15.6 $\mathrm{mol} / 100 \mathrm{~mol}$, respectively) and milk C15:0 (0.81 vs. $0.62 \mathrm{~g} / 100 \mathrm{~g}$ ), C17:0 (0.33 vs. $0.24 \mathrm{~g} / 100 \mathrm{~g})$ fatty acids, indicating predominance of amylolytic fermentation. Milk uric acid, a potential biomarker of rumen nitrogen flow and feed efficiency, was higher in A than M (133 vs. $102 \square \mathrm{mol} / \mathrm{L}$ ). Higher milk yield $(1.8$ vs. $1.7 \mathrm{~kg} / \mathrm{d})$ and $\mathrm{CH} 4$ emissions (28.5 vs. $25.9 \mathrm{~g} / \mathrm{d}$ ) in $A$ compared to $\mathrm{M}$ diet were observed, respectively. Use of tropical grasses, such as maralfalfa, in temperate climates could be a strategy to incorporate forage to feed the flock by farmers, because milk chemical composition did not change markedly and maralfalfa inclusion reduced $\mathrm{CH} 4$ emissions by goats.

Keywords: goat, maralfalfa, methane, milk yield 



\subsection{Introduction}

Forages are essential ingredient in ruminant diets. In the tropics, feed resources (i.e., grasses, legumes, tree foliage) differ from those of temperate regions due to their chemical and structural composition and digestibility. Tropical grasses generally use $\mathrm{C}_{4}$ metabolic pathways for photorespiration whereas most temperate grasses use $\mathrm{C}_{3}$ carbon fixation. Therefore, plants can be classified by the photosynthetic pathway they use. In $\mathrm{C}_{3}$ plants, the first photosynthetic products have 3-carbon structures, while the first products of $\mathrm{C}_{4}$ plants have 4-carbon structures. $\mathrm{C}_{4}$ grasses are found in all tropical grasslands and are dominant in warm-season temperate grasslands. Tropical $\mathrm{C}_{4}$ plants typically have lower $\mathrm{N}$ and higher cell wall concentrations than $\mathrm{C}_{3}$. The leaves of $\mathrm{C}_{3}$ plants are generally higher in protein than those of $\mathrm{C}_{4}$ plants under the same conditions. The $\mathrm{C}_{3}$ plants need higher moisture and have higher nutrient requirements. While $\mathrm{C}_{3}$ plants may produce higher quality feed, $\mathrm{C}_{4}$ plants nearly always produce more biomass (feed) than $\mathrm{C}_{3}$ plants over a 12-month period (Ehleringer and Cerling, 2002). C4 plants include the main grasses of the tropical savannahs including black spear grass, kangaroo grass and golden beard grass as well as crops like sugar cane, sorghum and corn. $\mathrm{C}_{3}$ 's crops include winter cereals, legumes, temperate pasture plants and all trees.

A typical temperate legume used in ruminant feeding is alfalfa (Medicago sativa). A tropical grass called maralfalfa (Pennisetum sp.) has been introduced in Europe as a forage e.g. due to the great adaptability from sea level to $3000 \mathrm{~m}$ altitude, and the high crop yield; i.e. $60 \mathrm{Tn} / \mathrm{ha} v \mathrm{~s}$. $20 \mathrm{Tn} / \mathrm{ha}$ for maralfalfa and alfalfa respectively (Márquez et al., 2007). Besides, maralfalfa is a grass with higher level of protein than typical grasses i.e. comparable to the content of protein in alfalfa. However, the available information about Pennisetum sp. as a forage to feed ruminants during lactation is scarce.

The objective or this experiment was to investigate the nutritive balance, milk yield, methane production and blood and milk metabolites when alfalfa hay and maralfalfa hay was used as a forage to supplement the concentrate feed in lactating goats. 


\subsection{Materials and methods}

The experimental procedures carried out were approved by the Committee on Animal Use and Care at the Polytechnic University of Valencia (Spain). Animals were cared by trained personnel and managed in accordance with the Spanish guidelines for experimental animal protection (Royal Decree No. 1201, 2005) and the European Convention for the Protection of Vertebrates used for Experimental and other Scientific Purposes (European Directive 86/609).

\subsubsection{Animals and feeding}

The experiment was conducted at the Experimental Farm belonging to the Polytechnic University of Valencia (Animal Science Department and ACUMA Research Center), Valencia (Spain). Ten multiparous mature Murciano-Granadina dairy goats in late lactation were selected and divided into two homogenous groups of five goats based on similar body weight $(45.7 \pm 2.96$ $\mathrm{kg}$ of BW), milk production in previous lactations (653 $\pm 63 \mathrm{~kg}$ of milk per $210 \pm$ 30 days of lactation, on average) and milk yield at the beginning of the experiment (1,850 $\pm 260.2 \mathrm{~g}$ of milk per day, on average), in a crossover design (2 treatments crossed with 2 period). Treatments consisted of two different mixed rations (Table 1). Goats were fed daily with $1.0 \mathrm{~kg}$ of forage and $1.5 \mathrm{~kg}$ concentrate (the ratio forage and concentrate was 40/60). Alfalfa and maralflafa hay were cut into $2.5 \mathrm{~cm}$ pieces (Cutter SkioldSaby A/S, Kjeldgaardsvej, DK 9300, Denmark) and the concentrate was mixed and pelleted along with the premix (Table 1); concentrate was the same for the two groups. One group was fed concentrate with alfalfa (Medicago sativa) as forage (A diet) and the other with maralfalfa (Pennisetum sp.) as forage (M diet). Nutrient requirements followed the recommendation of Lachica and Aguilera (2003) and Calsamiglia et al. (2009) for goats in lactation. Mixed diets were isoenergetic and isoproteic and half the daily ration was offered at 09:00 $\mathrm{h}$ and half at 16:00 h, respectively. Goats had free access to water.

\subsubsection{Experimental schedule and measurements}

Apparent total tract digestibility, gas exchange, energy partitioning, carbon $(\mathrm{C})$ and nitrogen $(\mathrm{N})$ balance, oxidation of nutrients, milk performance, 
fatty acids and metabolites were determined. The experiment was conducted in a crossover design in two $27 \mathrm{~d}$ periods. During the adaptation, goats were fed the experimental diets in pens for $10 \mathrm{~d}$ and then allocated to individual metabolism cages at thermoneutrality (20-23 ${ }^{\circ} \mathrm{C}$ determined by a Hobo probe, ONSET data loggers, Cape Cod, MA, USA) for $7 \mathrm{~d}$. Next, data on the feed offered and refused and the total fecal, urine and milk output were recorded daily for each goat during a $5 \mathrm{~d}$ period, as well as BW at the beginning and end of the period. Feces was collected in wire-screen baskets placed under the floor of the metabolism crates and urine was collected through a funnel into plastic buckets containing $1 \mathrm{M}$ sulphuric acid to maintain a pH below 5 for later analysis. Samples of forage and concentrate, faeces and urine were collected over 5 consecutive days and stored at $-20^{\circ} \mathrm{C}$, then pooled for chemical analysis. The goats were milked once daily at $08: 00 \mathrm{~h}$ with a portable milking machine (Flaco, model DL-170, J. Delgado S.A., Ciudad Real, Spain). Immediately after milking, the individual milk yield was measured and a representative sample was placed in a bottle and frozen until analysis. In addition, samples were collected into plastic vials that contained $20 \mathrm{mg}$ of potassium dichromate as a preservative and taken to the Interprofessional Dairy Laboratory of the Valencia Community Region (LICOVAL, Valencia, Spain) for compositional analysis (dry matter, crude protein, fat and lactose).

Ruminal fluid samples were collected by stomach tube before the morning feeding on the last day of the apparent digestibility trial. Ruminal fluid $\mathrm{pH}$ was immediately determined using a Model 265A portable $\mathrm{pH}$ meter (Orion Research Inc., Beverly, MA, USA). A ruminal fluid sample was acidified with 0.5 $\mathrm{M} \mathrm{H}_{2} \mathrm{SO}_{4}$ and frozen until later determination of $\mathrm{NH}_{3}-\mathrm{N}$. Samples for analysis of volatile fatty acids (VFA) were mixed with $\mathrm{H}_{3} \mathrm{PO}_{4}$ and kept frozen until analysis.

Then, gas exchange was measured for each goat during $24 \mathrm{~h}$ (5 goats/treatment) by a head-box designed for small ruminants. For this purpose, $10 \mathrm{~d}$ were taken for each period in the crossover design. The respirometry system has a head hood, a flow meter (Thermal Mass Flowmeter Sensyflow VT-S, ABB, Alzenau, Germany) and air suction provided by a centrifugal fan (CST60 Soler Palau Inc., Parets del Vallès, Barcelona, Spain). The methane $\left(\mathrm{CH}_{4}\right)$ and carbon dioxide $\left(\mathrm{CO}_{2}\right)$ concentration were measured using the infrared principle and oxygen $\left(\mathrm{O}_{2}\right)$ was measured by the paramagnetic principle 
(Easyflow Gas Analyzer, model 3020, ABB, Alzenau, Germany). Although the unit was an autocalibrated model, the analyzers were calibrated with reference gases before each test. Fernández et al. (2012; 2015) described the mobile open-circuit respirometry system used for these measurements. The whole system was calibrated by injecting pure $\mathrm{N}_{2}$ into the head box (McLean and Tobin, 1987), and determined gravimetrically using a precision scale. Calibration factors were calculated according to Brockway et al. (1971). The $\mathrm{CH}_{4}$ and $\mathrm{CO}_{2}$ production and $\mathrm{O}_{2}$ consumption were calculated as described by Aguilera and Prieto (1986). An initial atmospheric air sample was collected and the gas concentrations were used as reference for calculations.

\subsubsection{Chemical analyses}

Feed, feed refusal and faeces samples were first dried in a forced air oven at $55^{\circ} \mathrm{C}$ for $48 \mathrm{~h}$, then ground to pass a $1 \mathrm{~mm}$ screen. Urine was dried by lyophilisation. Dry matter (DM) of diets, refusal and faeces was determined by oven-drying at $102 \pm 2^{\circ} \mathrm{C}$ for $24 \mathrm{~h}$ (no. 934.01, AOAC, 2008). Ash concentration (no. 942.05, AOAC, 2008) was measured by incineration in an electric muffle furnace at $550 \stackrel{\circ}{\circ}$ for $6 \mathrm{~h}$ to determine organic matter (OM). Feed offered, orts and faeces were analysed for neutral detergent fibre (aNDF) and acid detergent fibre (ADF) using the ANKOM Fibre Analyzer (A220, ANKOM Technologies, Fairport, NY, USA) following procedures of Van Soest et al. (1991). The aNDF was determined using sodium sulphite and alpha amylase, both exclusive of residual ash. Ether extract (EE) was extracted with petroleum ether after acid hydrolysis to recover saponified fat (Soxtec System HT Tecator, Hillerød, Denmark; 1047 Hydrolyzing Unit and 1043 Extraction Unit) using no. 920.39 of AOAC (2008). Amounts of $C$ and $N$ were analysed by Dumas principle (TruSpec CN; Leco Corporation, St. Joseph, MI, USA) in a total combustion method (no. 968.06, AOAC, 2008). The NFC content of diets was calculated by difference method, based on chemical analysis of individual feeds as recommended by NRC (2001); NFC = $100-$ NDF - ash - CP - EE. Gross energy content of the dried samples (feed, faeces and urine) was analysed by combustion in an adiabatic bomb calorimeter (Gallenkamp Autobomb; Loughborough, UK). 
Milk composition (fat, protein, lactose and dry matter) was analyzed with an infrared analyzer (MilkoScan FT120 Foss Electric, Hillerød, Denmark). Fatty acid methyl esters of total milk lipids were prepared directly as previously described by O'Fallon et al. (2007). The fatty acid methyl esters were analyzed in a Focus Gas Chromatograph (Thermo, Milan, Italy) equipped with a split/splitless injector and a flame ionization detector. Separation of methyl esters was performed in a fused silica capillary column SPTM 2560 (Supelco, PA, USA) (100 m $\times 0.25 \mathrm{~mm} \times 0.2 \mu \mathrm{m}$ film thickness). The carrier gas was Helium at a linear velocity of $20 \mathrm{~cm} / \mathrm{sec}$. The samples were injected with a split ratio of $1 / 100$

$\mathrm{NH}_{3}-\mathrm{N}$ content of ruminal fluid samples was analyzed by the Kjeldahl procedure (2300 Kjeltec Analyzer Unit Foss Tecator, Hillerød, Denmark). Determination of ruminal VFA was based on the method described by Jouany (1982) using a gas chromatograph (Fisons 8000 series; Fisons Instruments $\mathrm{SpA}$, Milan, Italy) equipped with a split/splitless injector and flame ionization detector.

Minor milk constituents, i.e. glucose, glucose-6-phosphate, isocitrate, $\square$ hydroxybutyrate (BOHB), and uric acid (UA) were determined by enzymaticfluorometric methods (Larsen, 2015; Larsen 2014; Larsen and Nielsen, 2005; Larsen and Moyes, 2010, respectively). Creatinine, urea, uric acid, albumin, total protein, glucose, and triacylglycerides (TAG) were analysed according to standard procedures (Siemens Diagnostics ${ }^{\circledR}$ Clinical Methods for ADVIA 1650).

Non-esterified fatty acids (NEFA) were determined using the NEFA C ACS-ACOD assay method and phospholipids by the choline oxidase method both Wako assays (Wako Pure Chemicals, Japan). BOHB was determined as proposed by Harano et al. (1985). Fructosamine was determined by a colorimetric assay (reduction of nitrotetrazolium-blue), Roche Diagnostics $\mathrm{GmbH}$, D-68298 Mannheim. All analyses were performed using an autoanalyzer, ADVIA $1650{ }^{\circledR}$ Chemistry System (Siemens Medical Solutions, Tarrytown, NY 10591, USA).

Milk urea was analysed using flow injection analyses (FIA). Urease (EC 3.5.1.5) was added to the dilute milk sample; after the reaction a strong alkali solution was added and the developing ammonia was dialysed through a membrane. $\mathrm{pH}$ changes in the passing, aqueous phase was followed via a $\mathrm{pH}$ - 
indicator by spectrophotometer. Milk ammonium was analysed likewise, however without urease addition. Application notes given by the manufacturer was followed (Foss Tecator AB, Höganäs, Sweden).

\subsubsection{Calculations}

Metabolizable energy (ME) intake (MEI) was calculated as the difference between GE intake and energy losses in faeces, urine and $\mathrm{CH}_{4}$ (with an energy equivalent value of $39.5 \mathrm{~kJ} / \mathrm{L} \mathrm{CH}_{4}$; Brouwer, 1965).

Heat production was calculated according to Brouwer (1965) for $\mathrm{O}_{2}$ consumption, $\mathrm{CO}_{2}$ and $\mathrm{CH}_{4}$ production, and urine- $\mathrm{N}$ (Nur) as:

$$
\mathrm{HP}(\mathrm{kJ})=16.18 \times \mathrm{O}_{2}+5.02 \times \mathrm{CO}_{2}-2.17 \times \mathrm{CH}_{4}-5.99 \times \mathrm{Nur}
$$

Where gases were expressed in $L / d$ and Nur is urine nitrogen in $g / d$. Retained energy (RE) was calculated as the difference among MEI, HP and milk energy (Emilk).

Energy associated with the oxidation of protein (OXP), carbohydrate (OXCHO) and fat (OXF) was calculated by the method of Brouwer (1958) and Chwalibog et al. (1997) for ruminants:

OXP $=6.25 \times$ Nur $\times 18.42(\mathrm{~kJ} / \mathrm{g})$,

$\mathrm{OXCHO}=\left(-2.968 \times \mathrm{O}_{2}+4.174 \times \mathrm{CO}_{2 x}-2.446 \times \mathrm{Nur}\right) \times 17.58(\mathrm{~kJ} / \mathrm{g})$,

$\mathrm{OXF}=\left(1.719 \times \mathrm{O}_{2}-1.719 \times \mathrm{CO}_{2 x}-1.963 \times \mathrm{Nur}\right) \times 39.76(\mathrm{~kJ} / \mathrm{g})$.

Then, the HP from oxidation (HPx) was:

$\mathrm{HPx}(\mathrm{kJ})=16.18 \times \mathrm{O}_{2}+5.02 \times \mathrm{CO}_{2 x}-5.99 \times$ Nur.

Gases were expressed in $\mathrm{L} / \mathrm{d}$ and Nur in $\mathrm{g} / \mathrm{d}$ and the $\mathrm{CO}_{2}$ production from oxidation $\left(\mathrm{CO}_{2 \mathrm{x}}\right)$ was calculated as $\mathrm{CO}_{2}-\left(\mathrm{CO}_{2} / \mathrm{CH}_{4} \times \mathrm{CH}_{4}\right)$, according to Fahey and Berger (1988). Fermentation heat (HPf) was estimated subtracting HP from HPx. The non protein respiratory quotient for oxidation of nutrients (RQnpx) was determined as:

$$
R Q n p x=\left(\mathrm{CO}_{2 x}-(\text { Nur x } 6.25 \times 0.774)\right) /\left(\mathrm{O}_{2}-(\text { Nur x } 6.25 \times 0.957) .\right.
$$


The efficiency of use of ME for lactation was calculated according to AFRC (1993). Energy lost from the body, indicating mobilization of body fat reserves in support of milk secretion, was assumed to be used for milk synthesis with an efficiency of 0.84 and the concomitant energy storage during lactation was taken to be 0.95 times the milk secretion efficiency. Consequently, the corrected milk energy was estimated as $E_{\text {milk }}+(0.84 x$ negative energy retention $)+(1.05$ $x$ positive energy retention). The efficiency of use of ME for milk production $\left(k_{l}\right)$ was calculated as corrected milk energy/(ME $\left.-M_{m}\right)$, with $M E m$ being the metabolizable energy for maintenance, which was obtained from the estimation of NRC, 2007 (497 kJ/kg of BW $\left.{ }^{0.75}\right)$.

\subsubsection{Statistical analyses}

Data were analysed using the mixed model (proc MIXED) from SAS software (2001). The experiment was conducted as a crossover design; each goat received both treatments in two periods. Goat served as the experimental unit for all data. The model for the dependent variables included the fixed effect of diet and period with goat as random effect. The following statistical model was used; $Y=\mu+D+T+$ animal $+\varepsilon$, where $Y$ is the dependent variable; $\mu$ is the overall mean; $D$ and $T$ are the fixed effects of diet and period of time, respectively; animal is the random effect of goat and $\varepsilon$ is the random error. Least square means are reported throughout and differences were considered significant at $p<0.05$

\subsection{Results}

Maralfalfa (Pennisetum sp.) is a tropical grass $\left(\mathrm{C}_{4}\right.$ plant) with high level in protein (144 $\mathrm{g} / \mathrm{kg}$ of DM in our study) and similar to alfalfa (Medicago sativa) with a value of $161 \mathrm{~g} / \mathrm{kg}$ of DM in our trial (Table 2.1). Both were used as forage to supplement concentrate in a ratio forage concentrate of 40:60 (both mixed diets had a protein concentration of 164 and $158 \mathrm{~g} / \mathrm{kg}$ of DM for $\mathrm{A}$ and $\mathrm{M}$ diets, respectively).

The effect of the period and the interaction period $x$ diet were not significant and they did not appear on the tables.

Dry matter intake was larger and significant for A diet $(1.8$ vs $1.6 \mathrm{~kg} / \mathrm{d}$, respectively), and measured apparent digestibility coefficients were greater for 
$M$ vs. A (Table 2.2). The rumen parameters and volatile fatty acids are shown in Table 2.3. Propionic acid was higher $(P<0.05)$ in $M$ diet $(17.5 \mathrm{~mol} / 100 \mathrm{~mol})$ than in $A$ diet (15.6 mol/100 mol). Isovaleric, $n$-valeric and $n$-caproic were higher in group $A$ animals compared to $M$ animals.

Energy balance and oxidation of nutrients are shown in Tables 2.4 and 2.5 , respectively. For A diet (diet with inferior digestibility) greater loss of energy were found in feces, urine and methane in comparison with the $M$ diet. On the other hand, greater milk energy was observed in the A diet group of animals than in the $\mathrm{M}$ diet animals $\left(35.1 \mathrm{~kJ} / \mathrm{kg}\right.$ of $\mathrm{BW}^{0.75}$ greater). Oxidation of nutrients were higher $(P<0.05)$ in diet $A$ compared to $B$ for protein $(0.142$ vs. 0.116 , respectively) and fat (0.510 vs. 0.392). The oxidation of carbohydrates, however, was higher in the M group compared to the A group (0.492 vs. 0.347, respectively).

Individual differences in $\mathrm{C}$ and $\mathrm{N}$ balances were significant between $\mathrm{A}$ and $M$ diets, but no differences were observed in tissue energy retained as protein or fat (Table 2.6). Greater milk yield was found in the A group compared to the $\mathrm{M}$ group (1,764 vs. 1,656 g/day, respectively) but no differences were found in traditional macro components (Table 2.7). The fatty acid composition of milk fat is shown in Table 2.8. Significant differences were found in C15:0 and C17:0, being higher in $M$ than $A$ group.

The effect of diet on $\mathrm{CH}_{4}$ production is shown in Table 2.9. Higher $\mathrm{CH}_{4}$ emission was found in group $\mathrm{A}$ animals compared to group $\mathrm{M}$ animals (29 vs. $26 \mathrm{~g} / \mathrm{d}$, respectively) but these differences were not detected when $\mathrm{CH}_{4}$ production was expressed on DM intake basis or milk production. However, differences were found when $\mathrm{CH}_{4}$ emission were calculated on aNDF intake basis (50 vs. $46 \mathrm{~g} / \mathrm{d}$ for $A$ and $M$, respectively).

Metabolites in milk, urine and plasma are shown in Table 2.10. No differences were found for parameters related to fat mobilization (plasma BOHB and NEFA). The "long time" energy status parameter, fructosamine, suggests a little higher status among the A animals, however, this is not further supported by plasma glucose. Urea concentrations in milk and plasma are comparable as would be expected for an easily diffusible substance, no differences were found between diets. The uric acid concentration in milk, urine, and plasma was consistently greater in diet A compared to diet M. 


\subsection{Discusion}

\subsubsection{Intake, apparent digestibility and rumen parameters}

Spanish's small ruminant production systems are based on high use of concentrate and less pasture, and the most typical forage used is alfalfa hay (Calsamiglia et al., 2009). In recent years maralfalfa grass (Pennisetum sp.) have been introduced in Spain without any evidence of their practice in animal feeding. This research was carried out in order to used it as replacement of alfalfa hay and study their performance in lactating dairy goats.

Goats fed the A diet consumed $200 \mathrm{~g}$ more daily than those offered the $\mathrm{M}$ diet. Often, the $\mathrm{C}_{4}$ metabolic pathways lead to a higher rate and degree of deposition of lignin in plant tissue, a factor that may reduce voluntary intake (Wilson, 1994). Moreover, a high C:N ratio means the material is low in nitrogen. Alfalfa hay which is high in nitrogen, has a C:N ratio of $18: 1$, while maralfalfa, which is low in nitrogen, has a C:N ratio of 19:1 (Table 1). Almost the same difference in $\mathrm{C}: \mathrm{N}$ ration was observed on the mixed diets $\mathrm{A}$ and $\mathrm{M}$. It has been observed previously that animals prefer the higher nitrogen C3 plants in preference to the $\mathrm{C}_{4}$ plants, because they have a lower C:N ratio (Lauder, 2000).

The main difference among diets was the amount of aNDF and NFC, being higher and lower in diet $\mathrm{M}$, respectively. However, apparent digestibility was higher in $\mathrm{M}$ than $\mathrm{A}$ considering all nutrients. This could be explained by the quantity of fiber, which is larger in $\mathrm{M}$ diet, this in turn makes the ruminal content to remain a longer time in the rumen. The average rumen $\mathrm{pH}$ never fell below 6.2, so the values obtained can be considered sufficiently high to maintain normal rumen fermentation (Ørskov and Fraser, 1975).

Despite a higher fiber content of diet $\mathrm{M}$, rumen propionic acid was greater in this diet $(17.5 \mathrm{~mol} / 100 \mathrm{~mol}$ vs. $15.6 \mathrm{~mol} / 100 \mathrm{~mol}$, for $M$ and $A$ respectively). Other VFA's related with lipid metabolism as isovaleric, $\mathrm{n}$-valeric and $\mathrm{n}$-caproic, were greater in A diet compared to M. Other authors working with goats and maralfalfa obtained lower digestibility of DM in the group that was eating only maralfalfa (Sosa et al., 2006). 


\subsubsection{Energy balance and oxidation of nutrients}

Daily energy balance obtained with the two diets is listed in Table 2.4. We found greater GEI for $A$ than $M\left(118 \mathrm{~kJ} / \mathrm{kg}\right.$ of $\mathrm{BW}^{0.75}$ more), following the same pattern as DM intake. Higher energy losses in feces, urine and $\mathrm{CH}_{4}$ were found in $A$ than $M$, and no differences were found in $\mathrm{MEI}\left(1,089 \mathrm{~kJ} / \mathrm{kg}\right.$ of $\mathrm{BW}^{0.75}$, on average). Greater losses of energy in the form of $\mathrm{CH}_{4}$ seem to indicate greater fermentative activity in $\mathrm{A}$ than $\mathrm{M}$ diet. The tissue energy retained in the body was positive and did not differ between diets, even though energy content in milk was $35 \mathrm{~kJ} / \mathrm{kg}$ of $\mathrm{BW}^{0.75}$ higher in $\mathrm{A}$ than $\mathrm{M}$. Thus, the efficiency of ME for milk production was different between diets; higher efficiency was obtained in $A$ (0.64) than M (0.57). Different authors, obtained greater values, i.e. Aguilera et al. (1990) with lactating Granadina goats ( $\left.k_{l}=0.67\right)$; Bava et al. (2001) found values ranging from 0.60 to 0.73 for Saanen goats during lactation. Moreover, Tovar-Luna et al. (2010) investigated Alpine goats during lactation and found values ranging from 0.62 to 0.68 . Recently, Criscioni and Fernández (2015) found values of 0.72 for lactating goats at mid lactation when feeding mixed diets.

The contribution to HPx due to oxidation of nutrients with the two diets is shown in Table 2.5. HPx from OXP and OXF was grater in A vs. M and OXCHO greater in $\mathrm{M}$ vs. A. The ratio OXCHO/HPx was lower in A diet than $\mathrm{M}$ (0.347 vs. 0.492, respectively) and higher for OXF/HPx (0.510 vs. 0.392, respectively). This strongly indicates that diet $A$ has predominance of lipid metabolism and diet $\mathrm{M}$ on glucogenic metabolism. Chwalibog et al. (1997) reported that RQnpx lower than 1 indicates predominance of OXF vs. OXCHO, and under positive energy balance, part of the OXF should originate from ingested carbohydrate (mainly fiber) and diet fat content.

In ruminants, lipogenic nutrients originate either from fiber that stimulates the ruminal production of acetate and butyrate or from dietary fat, or they are derived from body reserves. Glucogenic nutrients originate from starch escaped from rumen degradation or gluconeogenesis. Lipogenic nutrients, which increase milk fat yield, increase the partitioning of $\mathrm{ME}$ into milk and consequently decrease the partitioning of ME into body reserves (Van Knegsel et al., 2007). The greater efficiency of diet A for milk production could be 
explained due to the fact that A diet behaved as a lipogenic diet and because better rumen fermentation has taken place. These observations suggest that glucogenic nutrients ( $\mathrm{M}$ diet) stimulate body fat deposition and the partitioning of $\mathrm{ME}$ into body tissue, so, greater, although no significant, $R \mathrm{E}_{\text {body }}$ was observed in the $\mathrm{M}$ group compared to the $A$ group $\left(92 \mathrm{vs}\right.$. $82 \mathrm{~kJ} / \mathrm{kg}$ of $\mathrm{BW}^{0.75}$, respectively).

\subsubsection{Carbon and Nitrogen Balance}

Microorganisms need beside carbon nitrogen/protein to build their functional cellular structure before they are able to break down plant material. The daily $\mathrm{C}$ and $\mathrm{N}$ balance and the calculated $\mathrm{C}$ and $\mathrm{N}$ ratio, are displayed in Table 6. Carbon intake and $\mathrm{N}$ intake were higher in $\mathrm{A}$ than $\mathrm{M}$, and although losses in feces and urine were higher in $A$ as well, the $C$ efficiency (Cmilk/Cintake) was greater in $A$ than $\mathrm{M} ; 0.19$ in $\mathrm{A}$ diet and 0.18 in $\mathrm{M}$ diet. Same scenery was found in $\mathrm{N}$ efficiency (Nmilk/Nintake); 0.27 and 0.25 for $\mathrm{A}$ and $M$ respectively. If $C$ and $N$ were expressed as $C: N$ ratio, lower $C: N$ intake was observed in A than M diet (15.5 vs. 15.8, respectively), opposite to the DM intake. This support the view that animals seek out the higher nitrogen C3 plants in preference to the C4 plants, as they have a lower C:N ratio (more nitrogen). The reason animals will select the more palatable C3 plants is in their quest to maximize protein intake (Lauder, 2000). Thus, the balance between $C$ and $\mathrm{N}$ could be an interesting tool to evaluate the performance of the animal.

\subsubsection{Milk yield and fatty acid profile}

Milk yield was $108 \mathrm{~g} / \mathrm{d}$ higher in $A$ than $M$ probably due to rumen cellulolytic fermentation (see VFA in Table 2.3) and greater energy efficiency for lactation ( $k_{1}$ of 0.64 and 0.57 in $A$ and $M$, respectively). Milk chemical composition was similar between diets, with a tendency $(P=0.082)$ to greater milk fat in A than $\mathrm{M}$ (Table 2.7).

Odd and branched chain fatty acid in milk are predominantly of microbial origin. Milk $\mathrm{C} 15: 0$ and C17:0 are potential biomarkers of rumen function since they are found in rumen bacterial lipids and may be partially synthesized endogenously from rumen substrates in the mammary gland (Fievez et al., 2012 and Vlaeminck et al., 2015). The differences found between treatments 
(higher contents of these fatty acids in the milk of $M$ goats) suggest an amylolytic rumen bacterial metabolism (Table 2.8). Milk concentrations of C15:0 and the sum of $\mathrm{C} 17: 0$ and cis-9 $\mathrm{C} 17: 1$ are positively related to propionate concentration in the rumen as these are synthesized from propionate de novo (Castro-Montoya et al. 2011). Further, propionate production is negatively related to $\mathrm{CH}_{4}$ production, suggesting a negative relationship between milk odd chain fatty acids concentration and $\mathrm{CH}_{4}$ production (van Lingen et al., 2014). Iso odd fatty acids are more abundant in cellulolytic bacteria, which in turn are usually related to higher $\mathrm{CH}_{4}$ production and, in contrast, amylolytic bacteria are generally enriched in linear odd fatty acid and associated with high starch diets which produce less $\mathrm{CH}_{4}$ (Fievez et al., 2012).

\subsubsection{Methane production and metabolites}

Some publications support the hypothesis that tropical $\mathrm{C}_{4}$ grasses are more metanogenic than temperate $C_{3}$ grasses (Kurihara et al., 1999; Ulyatt et al., 2002). As tropical forages are usually higher in fiber than temperate forages, many models assign higher estimates of $\mathrm{CH}_{4}$ production to them. This criterion is not applied to our study. Although $\mathrm{M}$ diet is higher in fiber and probably lignin, the slightly lower $\mathrm{C}: \mathrm{N}$ ratio in $\mathrm{A}$ diet caused better fermentation pattern and greater $\mathrm{CH}_{4}$ production. Table 2.9 shows a greater $\mathrm{CH}_{4}$ production in $\mathrm{A}$ than $\mathrm{M}$ (29 vs. $26 \mathrm{~g}$ per goat and day). However, when $\mathrm{CH}_{4}$ is expressed on DM intake or OM intake and milk basis no differences were observed. However, more $\mathrm{CH}_{4}$ production was found in diet A when it is expressed per aNDF intake (50 vs. 46 $\mathrm{g} / \mathrm{kg}$, for $A$ and $M$ respectively).

Metabolites in urine, plasma and milk are shown in Table 2.10. Plasma glucose is the obligatory precursor needed for milk lactose synthesis, where glucose $6 \mathrm{P}$ is an intermediate component also. No differences in milk lactose were found. However, interestingly, the glucose (ns) and the glucose 6P $(P<$ 0.05) content of the milk in the $\mathrm{M}$ group were higher compared to milk from the A group. Same tendency was observed by Larsen et al. (in press) who reported significantly higher levels $(P<0.001)$ of both monosaccharides in cows on a highly digestible ration compared to a lower digestible ration. The present goats were in positive energy balance and no significant differences were observed for the plasma metabolites related to fat mobilization, i.e. non esterified fatty 
acids, $\mathrm{BOHB}$ and glucose. Plasma fructosamine indicates that the $\mathrm{A}$ group has been in a little better energy status week back in time, however, this is not supported by other blood variables measured. Milk urea nitrogen is positively correlated with urea $\mathrm{N}$ concentration in blood plasma (Spek et al., 2013) and no differences were detected between treatments $(7.8 \mathrm{vs} .7 .1 \mathrm{mmol} / \mathrm{L}$ on average for plasma and milk). Milk uric acid has been considered a potential biomarker of rumen $\mathrm{N}$ flow and feed efficiency as it represents degradation products from e.g. synthesized microbial purines; others have questioned the predictive value of uric acid in milk (Timmermans et al. 2000). The A diet exhibited greater values of plasma uric acid than $\mathrm{M}$ diet $(59 \mathrm{mmol} / \mathrm{L}$ vs. $42 \mathrm{mmol} / \mathrm{L}$, respectively) and this trend was maintained in milk uric acid $(133 \mathrm{mmol} / \mathrm{L}$ vs. $102 \mathrm{mmol} / \mathrm{L}$, respectively). This higher concentration of uric acid in milk compared to blood plasma was explained by Giesecke et al. (1994) by a purine catabolism in the mammary gland through allantoin to uric acid. Interestingly, the same authors found, concurrent with the present study, a significant relationship between energy intake and milk uric acid. The A diet caused greater milk production (Table 7) and it seems reasonable to suggest that this is also influenced by microbial $\mathrm{N}$ synthesis because of the significant contribution of microbial protein to the ruminants protein requirements (Bjerre-HarpØth et al., 2012).

\subsection{Conclusions}

The present paper offers pioneer information of the use of maralfalfa as forage in mixed diets for lactating goats in temperate climate. A diet that incorporate alfalfa as forage showed better nutrient balance, ruminal parameters and milk yield although no significant effect was observed for milk chemical composition. The diet that combined concentrate with maralfalfa as forage showed lower fermentation performance due to the higher $\mathrm{C}: \mathrm{N}$ ratio of the diet, followed by greater propionic acid in the rumen. This was accompanied by higher $\mathrm{C} 15: 0$ and C17:0 levels in milk. Besides, the lower uric acid concentration in milk indicated lower microbial nitrogen flow, this may be due to less dietary carbohydrates available for microbial nitrogen production. However, use of tropical grasses, as maralfalfa, in temperate climates could be a strategy to incorporate forage to feed the flock by farmers, because milk composition did not change and maralfalfa apparently reduced $\mathrm{CH}_{4}$ emissions by goats. 


\subsection{References}

Agricultural and Food Research Council (AFRC). 1993. Energy and protein requirements of ruminants. CAB International, Wallingford, UK.

Aguilera, J.F., Molina, E., Prieto, C., Boza, J., 1986. Determination of energy requirements for maintenance in sheep of Segureña breed. Arch. Zootech. 35:89-96

Aguilera, J. F., Prieto, C., 1986. Description and function of an open-circuit respiration plant for pigs and small ruminants and the techniques used to measure energy metabolism. Arch. Anim. Nutr. 11:1009-1018.

Aguilera, J. F., Prieto, C., Fonollá, J., 1990. Protein and energy metabolism of lactating Granadina goats. Br. J. Nutr. 63:165-175.

Association of Official Analytical Chemists (AOAC), 2008. Official Methods of Analysis, 18th ed. Assoc. Off. Anal. Chem., Gaithersburg, MD.

Bava, L., Rapetti, L., Crovetto, A. G.M., Tamburini, A., Sandrucci, G., Galassi, Succi, G., 2001. Effect of a non-forage diet on milk production, energy and nitrogen metabolism in dairy goats throughout lactation. J. Dairy Sci. 84:2450-2459.

Bjerre-HarpØth, V., Friggens, N.C., Thorup, V.M., Larsen, T., Damgaard, B.M., Ingvartsen, K.L., Moyes, K.M., 2012. Metabolic and production profiles of dairy cows in response to decreased nutrient density to increase physiological imbalance at different stages of lactation. J. Dairy Sci. 95:2362-2380.

Brockway, J. M., Boyne, A.W., Gordon, J.G., 1971. Simultaneous calibration of gas analyzers and meters. J. Appl. Physiol. 31:296-297.

Brouwer, E., 1958. On simple formulae for calculating the heat expenditure and the quantities of carbohydrate and fat metabolized in ruminants, from data on gaseous exchange and urine N. Pages 182-194 in Proc. $1^{\text {th }}$ Symposium on Energy Metabolism. EAAP. Publ. 8. Academic Press, London.

Brouwer, E., 1965. Report of sub-committee on constants and factors. In: Blaxter, K.L. (Ed.), Proceedings of the Third EAAP Symposium on Energy Metabolism. Publication No. 11. Academic Press, London, pp. 441-443.

Calsamiglia, S., Bach, A., de Blas, C., Fernández C., García-Rebollar, P., 2009. Nutritional requirements for dairy ruminants. Fundación Española para el Desarrollo de la Nutrición Animal (FEDNA). Madrid, Spain. 
Castro-Montoya, J., Bhagwat, A.M., Peiren, N., De Campeneere, S., De Baets, B., Fievez, V., 2011. Relationships between odd- and branched-chain fatty acid profiles in milk and calculated enteric methane proportion for lactating dairy cattle. Anim. Feed Sci. Technol. 166:596-602.

Chwalibog, A., Tauson, A.H., Thorbek, G., 1997. Quantitative oxidation of nutrients in growing calves. Z. Ernährungswiss 36, 313-316.

Criscioni, P., Fernández, C., 2015. Effect of rice bran as a replacement for oat grain in energy and nitrogen balance, methane emissions, and milk performance of Murciano-Granadina goats. J. Dairy Sci. 99:1-11.

Ehleringer, J.R., Cerling, T.E., 2002. C3 and C4 photosynthesis. In: Munn, R.E. (Ed.), Encyclopedia of Global Environmental Change. The earth system: biological and ecological dimensions of global environmental change, vol. 2.Wiley, NY, pp. 186-190.

European Directive 86/609. Commission recommendations of 18 June 2007 on guidelines for the accommodation and care of animals used for experimentaland other scientific purposes. Annex II to European Council Directive 86/609. The Commission of the European Communittes Publishing, Brussels, Belgium.

Fahey, G.C., Berger, L.L., 1988. Carbohydrate nutrition of ruminants. In: Church, D.C. (Ed.), The Ruminant Animal. Digestive Nutrition and Physiology. Prentice-Hall, Englewood Cliffs, NJ, pp. 269-297.

Fernandez, C., Lopez, M.C., Lachica, M., 2012. Description and function of a mobile open-circuit respirometry system to measure gas exchange in small ruminants. Anim. Feed Sci. Technol. 172:242-246.

Fernández, C., López, M.C., Lachica, M., 2015. Low cost open-circuit hood system for measuring gas exchange in small ruminants: from manual to automatic recording. J. Agri. Sci. 153:1302-1309.

Fievez, V., Colman, E., Castro-Montolla, J.M., Stefanov, I., Vlaeminck, B., 2012. Milk odd- and branched-chain fatty acids as biomarkers of rumen functionAn update. Anim. Feed Sci. Technol. 172:51-65.

Giesecke, D., Ehrentreich, L., Stangassinger, M., and Ahrens, F. 1994. Mammary and renal excretion of purine metabolites in relation to energy intake and milk yield in dairy cows. J Dairy Sci, 77: 2376-2381. 
Harano, Y., Ohtsuki, M., Ida, M., Kojima, H., Harada, M., Okanishi, T., Kashiwagi, A., Ochi, Y., Uno, S., and Shigeta, Y. (1985). Direct automated assay method for serum or urine levels of ketone bodies. Clinica Chimica Acta, 151, 177-183.

Jouany, J. P., 1982. Volatile fatty acid and alcohol determination in digestive contents, silage juices, bacterial cultures and anaerobic fermentor contents. Sci. Aliments. 2:131-144.

Kurihara, M., Magner, T., Hunter, R.A., McCrabb, G,J., 1999. Methane production and energy partition of cattle in the tropics. Brit. J. Nutr. 81:227234.

Lachica, M., Aguilera, J.F. 2003. Estimation of energy needs in the free-ranging goat with particular reference to the assessment of its energy expenditure by the ${ }^{13} \mathrm{C}$-bicarbonate method. Small Rum. Res. 49:303-318.

Lauder, A., 2000. Good pastures are the key to profit. In: Heywood, J., Hodgkinson, K., Marsden, S., Pahl, L. (Eds.), Graziers' Experiences in Managing Mulga Country. Department of Primary Industries, Brisbane, pp. $52-62$.

Larsen, T. 2014. Fluorometric determination of free and total isocitrate in bovine milk. Journal of Dairy Science, 97: 7498-7504.

Larsen, T. 2015. Fluorometric determination of free glucose and glucose 6phosphate in cow's milk and other opaque matrices. Food Chemistry, 166: 283-286.

Larsen, T., Alstrup, L., and Weisbjerg, M.R. 2016. Minor milk constituents are affected by protein concentration and forage digestibility in the feed ration. $J$ Dairy Res. (in press)

Màrquez, F., Sánchez, J., Urbano, D., Dàvila, D., 2007. Evaluación de la frecuencia de corte y tipos de fertilización sobre tres genotipos de pasto elefante (Pennisetum purpureum). 1. Rendimiento y contenido de proteína. Zootecnia Tropical. 25(4): 253-259.

McLean, J. A., Tobin, G., 1987. Animal and Human Calorimetry. Cambridge University Press, Cambridge.

National Research Council (NRC). 2001. Nutrient requirements of dairy cattle. 7th rev. ed. Natl. Acad. Press, Washington, D.C. 
National Research Council (NRC), 2007. Nutrient Requirements of Small Ruminants. Sheep, Goats, Cervids and New World Camelids. National Academy Press, Washington, D.C.

O’Fallon, J.V., Busboom, J.R., Nelson, M.L., Gaskins, C.T., 2007. A direct method for fatty acid methyl ester synthesis: Application to wet meat tissues, oils, and feedstuffs. J. Anim. Sci. 85: 1511-1521.

Ørskov, E. R., Fraser, C., 1975. The effects of processing of barley -based supplements on rumen $\mathrm{pH}$, rate of digestion and voluntary intake of dried grass in sheep. Br. J. Nutr. 34:493-500.

Royal Decree No. 1201/2005 of 10 October on the protection of animals used for experimentation and other scientific purposes. Boletín del Estado, pp.34367-34391. Spanish Government Publishing, Madrid, Spain.

SAS (Statistical Analysis System). 2001. User's Guide, Version 8.02, Statistical Analysis System Institute Inc. Cary, NC, USA.

Sosa, D., Larco, C., Falconi, R., Toledo, D., Suárez, G., 2006. Digestibilidad de marlfalfa (pennisetum sp.) en cabras. Bol. Téc 6. Ser. Zool. 2:68-76.

Spek, J.W., Dijkstra, J., Van Duinkerken, G., Bannink, A., 2013. A review of factors influencing milk urea concentration and its relationship with urinary urea excretion in lactating dairy cattle. J. Agric. Sci. 151:407-423.

Timmermans, S.J, Johnson, L.M., Harrison, J.H., and Davidson, D. 2000. Estimation of the flow of microbial nitrogen to the duodenum using milk uric acid or allantoin. J Dairy Sci, 83: 1286-1299.

Tovar-Luna, I., Puchala, R., Sahlu, T., Freetly, H.C., Goetsch, A.L., 2010. Effects of stage of lactation and dietary concentrate level on energy utilization by Alpine dairy goats. J. Dairy Sci. 93:4818-4828.

Ulyatt, M.J., Lassey, K.R., Shelton, I.D., Walker, C.F., 2002. Methane emission from dairy cows and wether sheep fed subtropical grass-dominant pastures in midsummer in New Zealand. New Zealand J. Agric. Res. 45:227-234

Van Knegsel, A.T.M., Brand, H., Dijkstra, J., Straalen W.M., Heetkamp M.J.W., Tamminga, S., Kemp, B., 2007. Dietary energy source in dairy cows in early lactation: Energy partitioning and milk composition. J. Dairy Sci. 90:14671476. 
Van Lingen, H.J., Crompton, L.A., Hendriks, W.H., Reynolds, C.K., Dijkstra, J., 2014. Meta-analysis of relationships between enteric methane yield and milk fatty acid profile in dairy cattle. J Dairy Sci. 97:7115-7132.

Van Soest, P.J., Robertson, J.B., Lewis, B.A., 1991. Methods for dairy fiber, neutral detergent, and nonstarch polysaccharides in relation to animal nutrition. J. Dairy Sci. 74, 3583-3597.

Vlaeminck, B., Gervais, R., Rahman, M.M., Gadeyne, F., Gorniak, M., Doreau, M., Fievez, V., 2015. Postruminal synthesis modifies the odd- and branched-chain fatty acid profile from the duodenum to milk. J. Dairy Sci. 98:4829-4840.

Wilson, J.R., 1994. Cell Wall characteristics in relation to forage digestion by rumians. J. Agric. Sci. 122:173-182. 
Table 2.1. Ingredients and chemical composition of the diets (dry matter [DM] basis: $\mathrm{g} / \mathrm{kg} \mathrm{DM}$ ).

\begin{tabular}{|c|c|c|c|c|c|}
\hline & & & & & $\operatorname{Diet}^{\top}$ \\
\hline Ingredients, g/kg DM & Alfalfa & Maralfalfa & Concentrate & A & $M$ \\
\hline Alfalfa hay & 1000 & 1000 & & 400 & 400 \\
\hline Barley & & & 350 & 210 & 210 \\
\hline Corn & & & 309 & 185 & 185 \\
\hline Wheat bran & & & 150 & 90 & 90 \\
\hline Soy meal $(440 \mathrm{~g} / 100 \mathrm{~g} C P)$ & & & 148 & 89 & 89 \\
\hline Calcium carbonate & & & 22 & 13 & 13 \\
\hline Sodium chloride & & & 11 & 7 & 7 \\
\hline Bypass fat $^{2}$ & & & 5 & 3 & 3 \\
\hline Premix $^{3}$ & & & 5 & 3 & 3 \\
\hline \multicolumn{6}{|l|}{ Chemical composition } \\
\hline Dry matter & 940 & 934 & 984 & 966 & 964 \\
\hline Organic matter & 912 & 908 & 934 & 925 & 923 \\
\hline $\mathrm{CP}$ & 161 & 144 & 167 & 164 & 158 \\
\hline Ether extract & 13 & 9 & 21 & 18 & 16 \\
\hline aNDF & 522 & 610 & 182 & 318 & 353 \\
\hline ADF & 328 & 365 & 34 & 151 & 166 \\
\hline $\mathrm{NFC}^{4}$ & 216 & 144 & 564 & 425 & 396 \\
\hline Nitrogen & 26 & 23 & 27 & 26 & 25 \\
\hline Carbon & 461 & 444 & 440 & 448 & 442 \\
\hline C:N ratio & 18 & 19 & 16 & 17 & 18 \\
\hline Gross energy, $\mathrm{MJ} / \mathrm{kg} \mathrm{DM}^{5}$ & & & & 17 & 17 \\
\hline
\end{tabular}

${ }^{1} \mathrm{~A}=$ mixed diet with Alfalfa as forage; $\mathrm{M}=$ mixed diet with Maralfalfa as forage.

2 Bypass fat of palm fatty acid distillate. Provided by Norel Animal Nutrition, Norel S.A.,Spain. ${ }^{3}$ Provided by NACOOP S.A. España. Premix composition (ppm or UI per kilogram of premix): Se, 40; I, 250; Co, 80; Cu, 3000; Fe, 6000; Zn, 23400; Mn, 29000; S, 60000; Mg, 60000; vitamin A, 2000000 UI; vitamin D3, 400000; vitamin E, 2000 ppm; nicotinic acid, 10000; choline, 20300.

${ }^{4} \mathrm{NFC}=$ non fibrous carbohydrate content: $100-(\mathrm{NDF}+\mathrm{ash}+\mathrm{CP}+\mathrm{EE})$.

${ }^{5} \mathrm{DM}=$ dry matter. 
Table 2.2. Body weight, intake, and apparent digestibility coefficients of Murciano-Granadina goats $(n=10)$ during late lactation according to the type of diet.

\begin{tabular}{lcccc}
\hline & \multicolumn{2}{c}{ Diet $^{1}$} & & P-value \\
\hline Item $^{2}$ & $\mathrm{~A}$ & $\mathrm{M}$ & SEM $^{3}$ & Diet \\
\hline Body weight, $\mathrm{kg}$ & 45.9 & 45.6 & 0.45 & 0.31 \\
DMI, kg/d & 1.8 & 1.6 & 0.03 & 0.001 \\
Digestibility & & & & \\
DM & 703 & 759 & 8.1 & 0.003 \\
OM & 731 & 778 & 7.4 & 0.01 \\
CP & 688 & 736 & 8.1 & 0.002 \\
EE & 581 & 648 & 5.2 & 0.02 \\
aNDF & 560 & 609 & 3.4 & 0.04 \\
ADF & 400 & 480 & 9.2 & 0.04 \\
GE & 719 & 769 & 7.8 & 0.01 \\
\hline
\end{tabular}

${ }^{1} A=$ mixed diet with Alfalfa as forage; $M=$ mixed diet with Maralfalfa as forage. ${ }^{2} \mathrm{DMI}=$ dry matter intake; $\mathrm{DM}=$ dry matter; $\mathrm{OM}=$ organic matter; $\mathrm{EE}$ = ether extract; aNDF = neutral detergent fiber; $A D F=$ acid detergent fiber; GE = gross energy .

${ }^{3} \mathrm{SEM}=$ standard error of the mean. 
Table 2.3. $\mathrm{pH}$, ammonia- $\mathrm{N}\left(\mathrm{NH}_{3}-\mathrm{N}\right)$, and VFA of Murciano-Granadina goats $(\mathrm{n}=$ 10) during late lactation according to the type of diet.

\begin{tabular}{lcccc}
\hline \multicolumn{5}{c}{ Diet $^{1}$} \\
\hline Item $^{2}$ & $\mathrm{~A}$ & $\mathrm{M}$ & SEM $^{3}$ & P-value \\
\hline $\mathrm{pH}$ & 7.19 & 7.25 & 0.037 & 0.431 \\
$\mathrm{NH}_{3}$-N, mg/dL & 19.67 & 16.61 & 0.856 & 0.073 \\
Total VFA, mmol & 32.94 & 32.86 & 1.246 & 0.976 \\
Individual VFA, mol/100 mol & & & & \\
Acetic acid & 62.19 & 62.94 & 0.527 & 0.486 \\
Propionic acid & 15.59 & 17.52 & 0.365 & 0.007 \\
Butiric acid & 15.30 & 14.62 & 0.493 & 0.490 \\
isovaleric & 2.92 & 1.89 & 0.118 & 0.001 \\
n-valeric & 1.41 & 1.19 & 0.043 & 0.007 \\
n-caproic & 0.31 & 0.18 & 0.016 & 0.001 \\
heptanoic & 0.10 & 0.08 & 0.008 & 0.302 \\
\hline
\end{tabular}

${ }^{1} A=$ mixed diet with Alfalfa as forage; $M=$ mixed diet with Maralfalfa as forage.

${ }^{2} \mathrm{NH}_{3}-\mathrm{N}=$ ammonia nitrogen; $\mathrm{C}=$ carbon; $\mathrm{N}=$ nitrogen.

${ }^{3} \mathrm{SEM}=$ standard error of the mean. 
Table 2.4. Daily energy partitioning ( $\mathrm{kJ} / \mathrm{kg}$ of $\mathrm{BW}^{0.75}$ ) of Murciano-Granadina goats $(n=10)$ during late lactation according to the type of diet.

\begin{tabular}{lcccc}
\hline \multicolumn{5}{c}{ Diet $^{1}$} \\
Item
\end{tabular}

${ }^{1} A=$ mixed diet with Alfalfa as forage; $M=$ mixed diet with Maralfalfa as forage.

${ }^{2} \mathrm{GEI}=$ gross energy intake; $\mathrm{E}_{\text {feces }}=$ energy losses in feces; $\mathrm{E}_{\text {urine }}=$ energy losses in urine; $\quad E_{\text {methane }}=\quad$ energy losses in methane; $\mathrm{MEI}=$ metabolizable energy (ME) intake; $\mathrm{HP}=$ heat production; $\mathrm{RE}_{\text {total }}=$ total recovered energy; $\mathrm{Re}_{\text {milk }}=$ recovered energy in milk; $R E_{\text {body }}=$ recovered energy in tissue (REbody $=\mathrm{MEI}-\mathrm{HP}-$ Emilk). $\mathrm{k}_{\mathrm{l}}=$ efficiency of $M E$ for milk production $\left[k_{l}=\left(\right.\right.$ corrected $\left.E_{\text {milk }}\right) /\left(M E I-M E_{m}\right]$, being $M E_{m}=$ $497 \mathrm{~kJ} / \mathrm{kJ} / \mathrm{kg}$ of $\mathrm{BW}^{0.75}$ according to NRC (2007).

${ }^{3} \mathrm{SEM}=$ standard error of the mean. 
Table 2.5. Heat production ( $\mathrm{kJ} / \mathrm{kg}$ of $\mathrm{BW}^{0.75}$ ) from oxidation and fermentation; daily oxidation $\left(\mathrm{kJ} / \mathrm{kg}\right.$ of $\left.\mathrm{BW}^{0.75}\right)$ of protein, carbohydrate, and fat; and their contribution to the heat production from oxidation substrates of MurcianoGranadina goats $(n=10)$ during late lactation.

\begin{tabular}{lcccc}
\hline \multicolumn{5}{c}{ Diet $^{1}$} \\
Item
\end{tabular}

$1 \mathrm{~A}=$ mixed diet with Alfalfa as forage; $M=$ mixed diet with Maralfalfa as forage.

${ }^{2} \mathrm{HPx}=$ heat production from oxidation of nutrients; $\mathrm{HPf}=$ heat production of fermentation [HPf = HP - HPx (Brouwer, 1958)]; OXP = heat production associated with the oxidation of protein; $\mathrm{OXCHO}=$ heat production associated with the oxidation of carbohydrates; OXF = heat production associated with the oxidation of fat; RQnpx $=$ nonprotein respiratory quotient (unitless) from oxidation of nutrients $\{[\mathrm{CO} 2 \mathrm{x}-$ $($ Nurine $\times 6.25 \times 0.774)] /[\mathrm{O} 2-($ Nurine $\times 6.25 \times 0.957)]$, where $\mathrm{CO} 2=\mathrm{CO} 2$ production from oxidation and Nurine $=\mathrm{N}$ in urine .

${ }^{3} \mathrm{SEM}=$ standard error of the mean. 
Table 2.6. Carbon and nitrogen balance $\left(\mathrm{g} / \mathrm{kg}\right.$ of $\mathrm{BW}{ }^{0.75}$ ) of MurcianoGranadina goats $(n=10)$ during late lactation according to the type of diet.

\begin{tabular}{|c|c|c|c|c|}
\hline \multicolumn{5}{|c|}{$\operatorname{Diet}^{1}$} \\
\hline Item $^{2}$ & A & M & SEM $^{3}$ & P-value \\
\hline $\mathrm{C}_{\text {intake }}$ & 40.3 & 37.9 & 0.53 & 0.004 \\
\hline $\mathrm{C}_{\text {feces }}$ & 13.2 & 10.2 & 0.40 & 0.001 \\
\hline $\mathrm{C}_{\text {urine }}$ & 1.1 & 0.9 & 0.04 & 0.001 \\
\hline $\mathrm{C}_{\mathrm{CO} 2}$ & 15.3 & 16.6 & 0.22 & 0.006 \\
\hline $\mathrm{C}_{\mathrm{CH} 4}$ & 1.2 & 1.1 & 0.03 & 0.004 \\
\hline $\mathrm{C}_{\text {milk }}$ & 7.5 & 6.8 & 0.21 & 0.001 \\
\hline $\mathrm{C}_{\text {retained body }}$ & 1.8 & 1.9 & 0.33 & 0.912 \\
\hline$N_{\text {intake }}$ & 2.6 & 2.4 & 0.04 & 0.001 \\
\hline$N_{\text {feces }}$ & 0.8 & 0.6 & 0.02 & 0.001 \\
\hline$N_{\text {urine }}$ & 0.7 & 0.6 & 0.03 & 0.005 \\
\hline $\mathrm{N}_{\text {milk }}$ & 0.7 & 0.6 & 0.02 & 0.005 \\
\hline $\mathrm{N}_{\text {retained body }}$ & 0.4 & 0.5 & 0.03 & 0.102 \\
\hline \multicolumn{5}{|c|}{ Carbon and Nitrogen ratio } \\
\hline C:N intake & 15.5 & 15.8 & 0.05 & 0.001 \\
\hline $\mathrm{C}: \mathrm{N}$ feces & 16.5 & 16.3 & 0.17 & 0.359 \\
\hline $\mathrm{C}: \mathrm{N}$ urine & 1.5 & 1.4 & 0.03 & 0.161 \\
\hline C:N milk & 11.4 & 11.0 & 0.15 & 0.071 \\
\hline C:N retained body & 4.5 & 4.2 & 0.07 & 0.454 \\
\hline
\end{tabular}

${ }^{1} A=$ mixed diet with Alfalfa as forage; $M=$ mixed diet with Maralfalfa as forage.

${ }^{2} \mathrm{C}=$ Carbon; $\mathrm{N}=$ Nitrogen; $\mathrm{TE}=$ Tissue energy.

${ }^{3} \mathrm{SEM}=$ standard error of the mean. 
Table 2.7. Daily milk production and chemical composition $(\mathrm{g} / \mathrm{kg})$ of MurcianoGranadina goats $(n=10)$ during late lactation according to the type of diet.

\begin{tabular}{lcccc}
\hline \multicolumn{5}{c}{ Diet $^{1}$} \\
\hline Item & $\mathrm{A}$ & $\mathrm{M}$ & SEM $^{2}$ & P-value \\
\hline Milk yield, g/goat/day & 1764.0 & 1655.5 & 52.9 & 0.02 \\
Chemical composition & & & & \\
Dry matter & 148 & 146 & 1.1 & 0.19 \\
Fat & 51 & 48 & 0.9 & 0.08 \\
Protein & 43 & 44 & 0.5 & 0.30 \\
Lactose & 47 & 47 & 0.3 & 0.11 \\
\hline
\end{tabular}

${ }^{1} A=$ mixed diet with Alfalfa as forage; $M=$ mixed diet with Maralfalfa as forage.

${ }^{2} \mathrm{SEM}=$ standard error of the mean. 
Table 2.8. Fatty acid composition ( $\mathrm{g} / 100 \mathrm{~g}$ of identified fatty acids) of milk fat of Murciano-Granadina goats $(n=10)$ during late lactation according to the type of diet.

\begin{tabular}{lcccc}
\hline \multicolumn{4}{c}{ Diet $^{1}$} & \\
\hline Item $^{2}$ & $\mathrm{~A}$ & $\mathrm{M}$ & SEM $^{3}$ & P-value \\
\hline C4:0 & 0.16 & 0.16 & 0.004 & 0.761 \\
C6:0 & 0.55 & 0.54 & 0.014 & 0.854 \\
C8:0 & 1.13 & 1.10 & 0.030 & 0.604 \\
C10:0 & 6.36 & 6.18 & 0.124 & 0.493 \\
C12:0 & 4.31 & 4.02 & 0.172 & 0.433 \\
C13:0 & 1.97 & 2.57 & 0.224 & 0.194 \\
C14:0 & 6.58 & 7.70 & 0.704 & 0.457 \\
C14:1 & 0.17 & 0.18 & 0.015 & 0.642 \\
C15:0 & 0.62 & 0.81 & 0.056 & 0.018 \\
C16:0 & 24.51 & 25.27 & 0.592 & 0.555 \\
C16:1 & 0.66 & 0.78 & 0.069 & 0.42 \\
C17:0 & 0.24 & 0.33 & 0.026 & 0.048 \\
C17:1 & 0.13 & 0.15 & 0.011 & 0.383 \\
C18:0 & 3.25 & 3.78 & 0.271 & 0.356 \\
C18:1n9t & 0.93 & 0.91 & 0.174 & 0.960 \\
C18:1n9c & 9.14 & 9.75 & 0.626 & 0.655 \\
C18:1n7 & 0.26 & 0.20 & 0.030 & 0.338 \\
C18:2n6t & 0.16 & 0.15 & 0.020 & 0.947 \\
C18:2n6c & 2.47 & 2.10 & 0.112 & 0.098 \\
C20:0 & 0.09 & 0.10 & 0.006 & 0.338 \\
C18:3n6 & 0.00 & 0.01 & 0.003 & 0.616 \\
C20:1 & 0.04 & 0.04 & 0.005 & 0.701 \\
C18:3n3 & 0.23 & 0.14 & 0.026 & 0.090 \\
CLA 9c11t + 9t11c & 0.74 & 0.78 & 0.078 & 0.850 \\
C20:4n6 & 0.17 & 0.17 & 0.007 & 0.819 \\
Medium-chain fatty acids & 19.67 & 18.25 & 0.652 & 0.302 \\
Monounsaturated fatty acids & 18.08 & 18.25 & 1.011 & 0.939 \\
Polyunsaturated fatty acids & 6.00 & 5.13 & 0.271 & 0.108 \\
Saturated fatty acids & 75.91 & 76.62 & 1.064 & 0.760 \\
Al & 3.80 & 4.00 & 0.305 & 0.758 \\
\hline
\end{tabular}

${ }^{1} A=$ mixed diet with Alfalfa as forage; $M=$ mixed diet with Maralfalfa as forage ${ }^{2} \mathrm{CLA}=$ conjugated linoleic acid; $\mathrm{Al}=$ Atherogenicity index calculated as $\mathrm{C} 12: 0+4 \times \mathrm{C} 14: 0+$ C16:0/unsaturated fatty acids (Ulbricht and Southgate, 1991) ${ }^{3} \mathrm{SEM}=$ standard error of the mean. 
Table 2.9. Methane emission of Murciano-Granadina goats $(n=10)$ during late lactation according to the type of diet.

\begin{tabular}{lcccc}
\hline \multicolumn{5}{c}{ Diet $^{1}$} \\
\hline Item $^{2}$ & A & M & SEM $^{3}$ & P-value \\
\hline $\mathrm{CH}_{4}, \mathrm{~g} / \mathrm{d}$ & 28.5 & 25.9 & 0.65 & 0.002 \\
$\mathrm{Ym}, \%$ & 5.3 & 5.2 & 0.16 & 0.754 \\
$\mathrm{CH}_{4} / \mathrm{DMi}, \mathrm{g} / \mathrm{kg}$ & 15.8 & 16.2 & 0.50 & 0.226 \\
$\mathrm{CH}_{4} / \mathrm{OMi}, \mathrm{g} / \mathrm{kg}$ & 17.1 & 17.5 & 0.53 & 0.667 \\
$\mathrm{CH}_{4} / \mathrm{aNDFi}, \mathrm{g} / \mathrm{kg}$ & 49.8 & 45.8 & 1.87 & 0.012 \\
$\mathrm{CH}_{4} / \mathrm{milk}, \mathrm{g} / \mathrm{kg}$ & 16.2 & 15.6 & 0.67 & 0.188 \\
\hline
\end{tabular}

${ }^{1} A=$ mixed diet with Alfalfa as forage; $M=$ mixed diet with Maralfalfa as forage.

${ }^{2} \mathrm{Ym}=$ methane energy/gross energy intake; $\mathrm{DMi}=$ dry matter intake; $\mathrm{OMi}=$ organic matter intake; aNDFi = neutral detergent fiber intake.

${ }^{3} \mathrm{SEM}=$ standard error of the mean. 
Table 2.10. Metabolites in milk, urine and plasma of Murciano-Granadina goats $(n=10)$ during late lactation according to the type of diet.

\begin{tabular}{|c|c|c|c|c|}
\hline \multicolumn{5}{|c|}{$\operatorname{Diet}^{1}$} \\
\hline Item $^{2}$ & A & $\mathrm{M}$ & SEM $^{3}$ & P-value \\
\hline \multicolumn{5}{|l|}{ Milk } \\
\hline Glucose $6 \mathrm{P}, \mathrm{mmol} / \mathrm{L}$ & 0.14 & 0.18 & 0.01 & 0.03 \\
\hline Glucose, mmol/L & 0.13 & 0.15 & 0 & 0.13 \\
\hline $\mathrm{UA} \mu \mathrm{mol} / \mathrm{L}$ & 133 & 102 & 12.4 & 0.02 \\
\hline isocitrate, $\mathrm{mmol} / \mathrm{L}$ & 0 & 0.09 & 0 & 0.61 \\
\hline $\mathrm{BHBA}, \mu \mathrm{mol} / \mathrm{L}$ & 66 & 67 & 2.4 & 0.89 \\
\hline Urea, $\mathrm{mmol} / \mathrm{L}$ & 7.16 & 7.06 & 0.15 & 0.74 \\
\hline \multicolumn{5}{|l|}{ Urine } \\
\hline Urea/Creatinin, mmol/L & 103.9 & 111.2 & 11.2 & 0.67 \\
\hline Uric acid/creatinin,mmol/L & 0.21 & 0.15 & 0.048 & 0.08 \\
\hline Ammonia/creatinin mmol/L & 76.3 & 98.4 & 15.8 & 0.38 \\
\hline \multicolumn{5}{|l|}{ Plasma } \\
\hline Albumin, g/L & 37.2 & 38.5 & 0.39 & 0.10 \\
\hline Total protein, g/L & 85.4 & 80.3 & 0.89 & 0.003 \\
\hline Glucose, $\mathrm{mmol} / \mathrm{L}$ & 3 & 2.9 & 0.06 & 0.80 \\
\hline Urea, $\mu \mathrm{mol} / \mathrm{L}$ & 8 & 7.6 & 0.15 & 0.27 \\
\hline Uric acid, $\mu \mathrm{mol} / \mathrm{L}$ & 59.4 & 41.7 & 2.34 & 0.001 \\
\hline Triglycerides, mmol/L & 0.1 & 0.1 & 0 & 0.84 \\
\hline Fructosamin, $\mu \mathrm{mol} / \mathrm{L}$ & 281 & 258 & 3 & 0.001 \\
\hline Ammonium, $\mu \mathrm{mol} / \mathrm{L}$ & 157 & 140 & 4.2 & 0.04 \\
\hline BHBA & 0.4 & 0.4 & 0.02 & 0.97 \\
\hline NEFA, $\mu$.eqv./L & 322 & 397 & 37.5 & 0.32 \\
\hline Phosphorlipid, mmol/L & 1.4 & 1.7 & 0.05 & 0.001 \\
\hline
\end{tabular}

${ }^{1} \mathrm{~A}=$ mixed diet with Alfalfa as forage; $\mathrm{M}=$ mixed diet with Maralfalfa as forage. ${ }^{2} \mathrm{BHBA}=$ Beta-Hydroxybutyrate; NEFA = nonesterified fatty acids.

${ }^{3} \mathrm{SEM}=$ standard error of the mean. 
Heat Production Partition in Sheep Fed above Maintenance from Indirect Calorimetry Data

Open Journal of Animal Sciences 5 (2015) 198-209. doi: 10.4236/ojas.2015.5202 

Heat Production Partition in Sheep Fed above Maintenance from Indirect Calorimetry Data

Patricia Criscioni ${ }^{1}$, María del Carmen López ${ }^{1}$, Victor Zena ${ }^{2}$, Carlos Fernández ${ }^{1 *}$

${ }^{1}$ Research Center ACUMA, Animal Science Department, Polytechnic University of Valencia, Valencia, Spain 2Interuniversity Institute of Bioengineering Research and Technology Oriented to the Human Being, Universidad Politécnica de Valencia, Valencia, Spain

Email: *cjfernandez@dca.upv.es 



\subsection{Abstract}

The objective of this study is to compare the partition of heat energy (HE) in two sheep breeds by indirect calorimetry and integral calculus. An experiment was conducted with two Spanish native sheep breeds (dry and non-pregnant) which were fed with pelleted mixed diets above maintenance. Six Guirras and six Manchegas breed sheep were selected (58.8 \pm 3.1 and $60.2 \pm 3.2 \mathrm{~kg}$ body weight, respectively). All sheep were fed with the same concentrate mixed ration $(0.300 \mathrm{~kg}$ cereal straw as forage and $0.700 \mathrm{~kg}$ concentrate) in two meals. Half the daily ration was offered at $800 \mathrm{~h}$ and another half at $1600 \mathrm{~h}$. The sheep had free access to water. Sheep were allocated in metabolic cages; energy balance and gas exchange were assessed in each sheep. The statistical analyses in- cluded the fixed effect of breed and random effect of sheep. The metabolic energy (ME) for main- tenance represented $69 \%$ of the total ME intake and the average was $354 \mathrm{~kJ}$ per $\mathrm{kg}$ of metabolic body weight $\left(\mathrm{kg}^{0.75}\right.$ of BW) on average. The basal metabolism (HeE) was greater $(p<0.05)$ in Guirra than Manchega breed $\left(270 \pm 18\right.$ vs. $247 \pm 15 \mathrm{~kJ} / \mathrm{kg}$ of $\mathrm{BW}^{0.75}$ and day). As sheep were fed with above maintenance, the retained energy in the body accounted for $22 \%$ of the ME intake and $77 \%$ of the ME intake was lost as heat. $51 \%$ of the $\mathrm{MEl}$ was converted to $\mathrm{HeE} ; 5 \%$ was lost as physical activity of standing and lying down $(\mathrm{HjE})$, and $13 \%$ was associated with the process of feeding and work of digestion and metabolism (HdE). Within HdE, 47\% represented the cost of intake and feeding and 54\% the cost of digestion and metabolism. No differences in HE partition between breeds were found, although Guirra breed showed less efficiency of energy retention than Manchega breed. Therefore, this study demonstrated a tentative approach of partitioning $\mathrm{HE}$, combining indirect calorimetry and integral calculus.

Keywords: Sheep, Heat Production Partition 



\subsection{Introduction}

In the last few decades a great number of efforts have been devoted to measuring energy expenditure in animals. Animals produce heat from a variety of metabolic processes such as maintenance, thermoregulation, physical activity and production (e.g. deposition of body tissue, and milk production). Indirect calorimetry has played an important role in measuring this energy released as heat or heat production (HE). In open circuit respiration chambers, heat production can be calculated based on the measurements of $\mathrm{O}_{2}$ consumption and $\mathrm{CO}_{2}$ production.

The direct measurement of $\mathrm{HE}$ by indirect calorimetry offers the opportunity to evaluate variations among animals in line with their genotype, phenotype or environmental conditions. Heat energy can be further partitioned into that associated with basal metabolism, voluntary activity, product formation, digestion and absorption, thermal regulation, heat of fermentation, and waste formation and excretion. Partition of HE into meaningful physiological or metabolic components is the most difficult and controversial aspect of all feeding systems [1]. The calculation of heat increment in producing animals needs the partitioning of total HE between a component due to maintenance and a component due to production. The fasting heat production (FHP) post feeding depends on the previous feeding level, and length of fasting, and often includes a contribution of physical activity. Therefore, ac- tivity related total HE is the most variable component of total energy expenditure [2].

Calorimetric techniques can provide direct access to total $\mathrm{HE}$, and experimental interventions and computational techniques are required to disentangle its components [3].

The objective of this study is to present the methodology developed in our laboratory to monitor total HE and the heat increment associated with feeding in two sheep breeds by employing indirect calorimetry and mathematical calculus. 


\subsection{Materials and methods}

\subsubsection{Animals and feeding}

The experimental procedure was approved by the Animal Use and Care Committee of the Polytechnic University of Valencia (Spain) and followed the codes of practice for animals used in experimental works proposed by the European Union [4].

Twelve multiparous, dry and non-pregnant sheep of two Spanish native breeds were used in this experiment. Guirra breed belong to Valencia Province and Manchega breed to Castilla-La Mancha Province (Spain), both are autochthonous breeds and almost no information about energy partitioning is available from these breeds. Energy metabolism information would be useful for energy requirements purposes. Six Guirras and six Manchegas breed sheep were selected, which had similar body weight $(58.8 \pm 3.1$ and $60.2 \pm 3.2 \mathrm{~kg}$ of BW, respectively). It is a mature weight for Guirra [5] and almost for Manchega [6]; mature weight in females Guirra and Manchega ranged between 50 - 60 and $65-75 \mathrm{~kg}$, respectively. The experiment was conducted as a random design with the two breeds as fixed effect. All sheep were fed the same concentrate mixed ration $(0.300 \mathrm{~kg}$ cereal straw as forage and $0.700 \mathrm{~kg}$ concentrate) in two meals. Half the daily ration was offered at $800 \mathrm{~h}$ and half at $1600 \mathrm{~h}$, respectively. Sheep had free access to water. The concentrate was mixed and pelleted along with the premix. Its chemical composition values on dry matter (DM) basis was $92.62 \%$ organic matter (OM), $17.19 \%$ crude protein (CP), 47.33\% neutral detergent fiber (NDF), 25.37\% acid detergent fiber (ADF), $8.45 \%$ starch and $18.94 \mathrm{MJ}$ of gross energy (GE) per $\mathrm{kg} \mathrm{DM}$, following the recommendation of [7] for sheep. Chemical composition of cereal straw was: 91.30\% OM, 4.21\% CP, $77.54 \%$ NDF, 50.33\% ADF and $0.91 \%$ of starch.

\subsubsection{Experimental Schedule and Measurements.}

Sheep were fed with experimental diets in pens for 10 days. Once adapted to the diet, the sheep were allocated in metabolic crates for 10 more days, in thermoneutral conditions $\left(20^{\circ} \mathrm{C}\right.$ to $23^{\circ} \mathrm{C}$ as determined by a Hobo probe, ONSET data loggers, Cape Cod, MA, USA). Feed intake, refusals, urine and faeces were collected, weighed and recorded daily for each sheep over a 
collection period of 5 days. Faeces were collected in wire-screen baskets placed under the floor of the metabolic crates and urine was collected through a funnel into plastic buckets containing 100 mlsulphuric acidto maintain a pH below 3 for later analysis. Samples of forage and concentrate, refusals, faeces and urine were stored at $-20^{\circ} \mathrm{C}$, and then pooled for chemical analysis. Ruminal fluid samples were collected by stomach tube before the morning feeding on the last day of the sample collection period. Ruminal fluid $\mathrm{pH}$ was immediately determined using a Model 265A portable pH meter (Orion Research Inc., Beverly, MA, USA). A ruminal fluid sample was acidified with $\mathrm{H}_{2} \mathrm{SO}_{4}$ and frozen until later determination of ammonia nitrogen (ammonia-N). Samples for analysis of volatile fatty acids (VFA) were mixed with $\mathrm{H}_{3} \mathrm{PO}_{4}$ and kept frozen until analysis.

The body weight of each animal was taken at the beginning of the diet adaptation period and at the end of the recollection period.

Gaseous exchange was measured for each ewe during $24 \mathrm{~h}$ (6 sheep per breed, one animal per day) using a mobile open-circuit respirometry system (head-hood) designed for small ruminants.

As half the daily ration was offered at 8:00 $h$ and half at 16:00 $h$, twice a day the head hood drawer was opened, leaving the food and a bucket of water inside. In order to measure fasting, three sheep per breed were randomly selected, and deprived of food for 3 days and the gaseous exchange measurement was done on day 4 .

The respirometry system has a head hood, a flow meter (Thermal Mass Flowmeter Sensyflow VT-S, ABB, Alzenau, Germany) and air suction provided by a centrifugal fan (CST60 Soler Palau Inc., Parets del Vallès, Barcelona, Spain). The methane $\left(\mathrm{CH}_{4}\right)$ and carbon dioxide $\left(\mathrm{CO}_{2}\right)$ concentration were measured using the infrared principle and oxygen $\left(\mathrm{O}_{2}\right)$ was measured by the paramagnetic principle (Easyflow Gas Analyzer, model 3020, ABB, Alzenau, Germany). Although the unit was an autocalibrated model, the analysers were calibrated with reference gases before each test.

Fernández et al. [8] described the mobile open-circuit respirometry system used and the differences now are that we use a head hood instead of a facemask and, the gas exchange data acquisition is continuous. We described 
it briefly: The system was capable to record data at intervals of 1 second. Gas analyzer unit and flow meter was connected to the computer (Fujitsu Siemens Lifebook Series, Pentium 4 laptop, Munich, Germany) by an universal serial bus (USB) connector. A serial communication protocol was used with its programmable logic controllers (MODBUS Organization, Inc., Hopkinton, MA, USA; www.modbus.org) for communication between the analytical devices (analyser unit and flow meter) and the computer. The electronics prototyping platform Arduino (www.arduino.cc) was used to send data from the gas analyser unit to LabVIEW7.1 (National Instruments, Austin, Texas, USA) by RS232 protocol in real time. The flow meter was monitored by a 10 bitanalog to digital converter (model DS2438; Maxim Integrated Products, Inc. Sunnyvale, CA, USA).

The whole system was calibrated injecting pure $\mathrm{N}_{2}$ into the head box [9], determined gravimetrically using a precision scale. Calibration factors were calculated according to [10]. The $\mathrm{CH}_{4}$ and $\mathrm{CO}_{2}$ production and $\mathrm{O}_{2}$ consumption were calculated as described by [11]. An initial atmospheric air sample was collected and the gas concentrations were used as reference for calculations.

\subsubsection{Chemical Analysis}

Feed, feed refusal and feces samples were first dried in a forced air oven at $55^{\circ} \mathrm{C}$ for $48 \mathrm{~h}$ then ground to pass a $1 \mathrm{~mm}$ screen before analysis. Urine was dried by lyophilization. Chemical analyses of the diet, refusals and feces were conducted according to methods of [12] for DM and ash. DM of diets and feces was determined by oven drying at $102^{\circ} \mathrm{C} \pm 2^{\circ} \mathrm{C}$ for $24 \mathrm{~h}$. Ash concentration was measured by incineration in an electric muffle furnace at $550^{\circ} \mathrm{C}$ for $6 \mathrm{~h}$ to determine OM. The NDF and ADF were measured in an ANKOM Fiber Analyzer (A220, ANKOM Technologies, Fairport, NY, USA) according to [13] and [12], respectively. NDF was determined using sodium sulfite and alpha amylase.

Starch content was determined by enzymatic method ( $\alpha$-amylase obtained from Sigma-Aldrich, Steinheim, Germany) according to [14]. The nitrogen $(\mathrm{N})$ from feed, feces and urine were analysed by the Dumas principle 
(TruSpec CN; LECO Corporation, St. Joseph, MI, USA). Multiplying $\mathrm{N}$ by a factor of 6.25 converted the results to CP. The GE content of the dried samples (feed, feces and urine) was analyzed by combustion in an adiabatic bomb calorimeter (Gallenkamp Autobomb; Loughborough, UK).

$\mathrm{NH}_{3}-\mathrm{N}$ content of ruminal fluid samples was analyzed by the Kjeldahl procedure (2300 Kjeltec Analyzer Unit Foss Tecator, Hillerød, Denmark). Determination of ruminal VFA was based on the method described by [15] using a gas chromatograph (Fisons 8000 series; Fisons Instruments SpA, Milan, Italy) equipped with a split/ splitless injector and flame ionization detector.

\subsubsection{Calculations}

The metabolizable energy intake (MEI) was calculated as the difference between gross energy intake (GEI) and energy losses in feces, urine and $\mathrm{CH}_{4}$ (with an energy equivalent value of $39.5 \mathrm{~kJ} / \mathrm{L} \mathrm{CH}_{4}[16]$.

The $\mathrm{HE}$ was determined from measurements of $\mathrm{O}_{2}$ consumption, $\mathrm{CO}_{2}$ and $\mathrm{CH}_{4}$ production, and urine $\mathrm{N}$ (Nur), using the equation [16]:

$$
\mathrm{HE}(\mathrm{kJ})=16.18 \times \mathrm{O}_{2}+5.02 \times \mathrm{CO}_{2}-2.17 \times \mathrm{CH}_{4}-5.99 \times \mathrm{Nur}
$$

Where gases were expressed in liters per hours and Nur in grams per day. The body tissue energy (REbody) was calculated as MEI - HE.

The energy associated with the oxidation of protein (OXP), carbohydrate $(\mathrm{OXCHO})$ and fat (OXF) was cal- culated by the method of [17] and [18] for ruminants. The production of volatile fatty acid from carbohydrate fermentation is followed by $\mathrm{CO}_{2}$ and $\mathrm{CH}_{4}$ production. $\mathrm{A}$ ratio $\mathrm{CO}_{2}: \mathrm{CH}_{4}$ of $3: 1$ and 1.7:1 for high grain and high forage diets, respectively [19]. The $\mathrm{CO}_{2}$ production from oxidation $\left(\mathrm{CO}_{2 \mathrm{x}}\right)$ was calculated as $\mathrm{CO}_{2}-\left(\mathrm{CO}_{2}: \mathrm{CH}_{4} \times \mathrm{CH}_{4}\right)$.

The calculations were carried as following:

$$
\begin{aligned}
& \mathrm{OXP}=6.25 \times \mathrm{Nur} \times 18.42(\mathrm{~kJ} / \mathrm{g}), \\
& \mathrm{OXCHO}=\left(-2.968 \times \mathrm{O}_{2}+4.174 \times \mathrm{CO}_{2 \times}-2.446 \times \mathrm{Nur}\right) \times 17.58(\mathrm{~kJ} / \mathrm{g}), \\
& \mathrm{OXF}=\left(1.719 \times \mathrm{O}_{2}-1.719 \times \mathrm{CO}_{2 \mathrm{x}}-1.963 \times \mathrm{Nur}\right) \times 39.76(\mathrm{~kJ} / \mathrm{g}) .
\end{aligned}
$$


Then, the $\mathrm{HE}$ from oxidation $(\mathrm{HxE})$ was:

$$
\mathrm{HxE}(\mathrm{kJ})=16.18 \times \mathrm{O}_{2}+5.02 \times \mathrm{CO}_{2 x}-5.99 \times \text { Nur. }
$$

Gases were expressed in liters perhours and Nur in grams per day. The non protein respiratory quotient from oxidation of nutrients (RQnpx) was determined as:

$$
R Q n p x=\left(\mathrm{CO}_{2 x}-(\text { Nur } \times 6.25 \times 0.774)\right) /\left(\mathrm{O}_{2}-(\text { Nur } \times 6.25 \times 0.957) .\right.
$$

As we mentioned above, retained or recovered energy was determined as the difference between $\mathrm{MEI}$ and the HE. Heat energy associated with REbody ( $\mathrm{HrE})$ and $\mathrm{ME}$ used for tissue gain (MEr) were based on an assumed ef- ficiency of dietary ME use for tissue gain of 0.75 [20].

Therefore, $M E$ for maintenance (MEm) was estimated by difference between MEI and MEr, and the efficiency of use of ME for maintenance $(\mathrm{km})$ as basal metabolic rate over MEm. The $\mathrm{N}$ balance ( $\mathrm{N}$ retained) was determined as well, by difference among $\mathrm{N}$ intake and feces plus urine.

\subsubsection{Heat Production Partition}

The total HE consist of many components: basal metabolism (HeE), heat associated with voluntary activity $(\mathrm{HjE})$, heat of product formation $(\mathrm{HrE})$, heat for thermal regulation $(\mathrm{HcE})$, heat of synthesis and excretion of waste products $(\mathrm{HwE})$, heat of digestion $(\mathrm{HdE})$ and heat of fermentation $(\mathrm{HfE})$. This energy terms was defined accord- ing to [1].

$$
\mathrm{HE}=\mathrm{HeE}+\mathrm{HjE}+\mathrm{HrE}+\mathrm{HcE}+\mathrm{HwE}+\mathrm{HdE}+\mathrm{HfE} .
$$

Due to the animals being in a thermoneutral and non stressful environment, HcE was assumed to be zero. The NRC [1] defines the heat increment of feeding (HiE) as:

$$
\mathrm{HiE}=\mathrm{HrE}+\mathrm{HdE}+\mathrm{HfE}+\mathrm{HwE} .
$$

In our trial we considered HwE negligible and,

$$
H f E=H E-H x E .
$$


Therefore, the HE was partitioned between components due to feed intake, physical activity, and basal metabolic rate. This partitioning is described as follows.

$$
H E=H e E+H j E+H i E .
$$

The maintenance requirements consist of basal metabolic rate plus the activity increment, and are usually defined as FHP; therefore we define FHP as a sum of two components; $\mathrm{HeE}$ and $\mathrm{HjE}$. The HeE corresponded to the minimum energy expenditure of resting, healthy, non-reproductive, fasting and adult animal that are in a ther- moneutral environment during the inactive circadian phase [21].

The activity increment was assumed in our study as the difference between FHP and HeE.

$$
\mathrm{HjE}=\mathrm{FHP}-\mathrm{HeE} .
$$

The term defined by NRC [1] as heat of digestion ( $\mathrm{HdE})$ includes the energy cost of eating, rumination, work of digestion and nutrient metabolism. The HdE was determined as follows:

$$
\mathrm{HdE}=\mathrm{HE}-\mathrm{HeE}-\mathrm{HrE}-\mathrm{HjE} .
$$

Then, $\mathrm{HdE}$ was divided in $\mathrm{HE}$ of eating $(\mathrm{HdEe})$ and $\mathrm{HdE}$ of digestion and metabolism (HdEdm).

The cost of eating is defined in the literature as the act of prehending, biting, chewing, salivating and swallowing throughout a time period (use to be 15 minutes, according to [22] and [2]). In our study the cost of eating ( $\mathrm{HdEe})$ is guided by the increase in HE from the moment that feed is offered on the feeder to 3 hours later, and we measure the peak area under the curve. The HdEdm was obtained by difference and we assumed included the work of digestion and metabolism.

The two HdE components include rumination and must include the energy cost (oxygen consumption) of gastrointestinal and hepatic organs, although each of these activities was not quantifies. 


$$
\mathrm{HdE}=\mathrm{HdEe}+\mathrm{HdEdm} .
$$

Figure 1 shows some nomenclature described above and we can realize that the partition of $\mathrm{HdE}$ in $\mathrm{HdEe}$ and HdEdm is theorical, based on the curve pattern of the metabolic rate $(\mathrm{HE})$.

\subsubsection{Datal Analyses}

The quantification of partitioning $\mathrm{HE}$ was developed by integral calculus in $\mathrm{R}$ (version 2.12.2, $\mathrm{R}$ Foundation for Statistical Computing, Viena, Austria). Duration of gas exchange was fixed at 1 day, and the time unit was minutes.

The integrated areas were:

$\mathrm{HE}=$ The Total Heat Production in fed and fasted animal was determined using integral of curves formed by data from indirect calorimetry.

$\mathrm{HiE}=$ Difference of integrals of HE and FHP.

$\mathrm{FHP}=$ Integral of fasting heat production, divided in $\mathrm{HeE}$ and

HjE. HjE = Difference of integrals FHP and HeE.

HeE value was determined as the area under the curve defined by the value repeated more frequently (mode) of the mean values of data obtained from the respirometry of 3 fasting animals, once the highest values were dropped, which could be caused by movements.

$\mathrm{HdEe}=$ Difference of integrals of total HE and FHP in an approximate 3-hour period after feeding.

$\mathrm{HfE}=$ Is the difference between integrals of $\mathrm{HE}$ and $\mathrm{HxE}$.

Definite integral of a signal can be interpreted as the area under the curve. This numeric integration allows us to evaluate the defined integral of a continuous function in a closed interval with the desired accuracy, and it consists in the adjustment of a polynomial to a set of points and then integrating them. 
The integral of each curve was based on the trapezium method. The sum of these areas of trapeziums can be approximated to the integral that represents the area under the curve, according to the following equation:

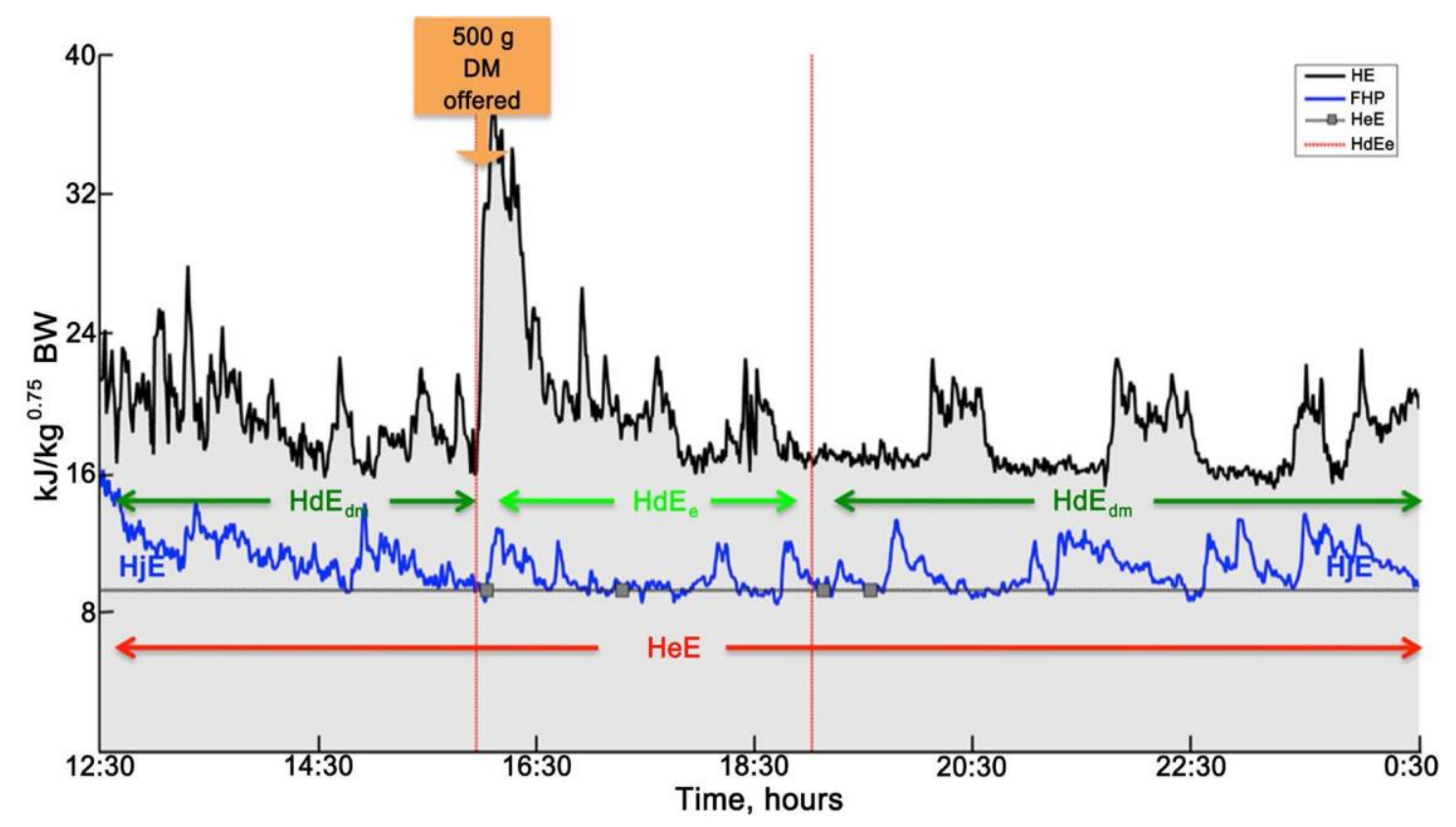

Figure 1. Example of heat production (HE) partitioning and their components: fasting heat production (FHP), basal metabolism (HeE), heat associated with voluntary activity $(\mathrm{HjE})$, heat of digestion $(\mathrm{HdE})$, heat of feeding during 3 hours $\left(\mathrm{HdE}_{\mathrm{e}}\right)$, heat after 3 hours of feeding to next intake $\left(\mathrm{HdE}_{\mathrm{dm}}\right) . \mathrm{FHP}=\mathrm{HeE}+\mathrm{HjE} ; \mathrm{HdE}=\mathrm{HdE}_{\mathrm{e}}+\mathrm{HdE}_{\mathrm{dm}}$.

$$
S_{\alpha}=\sum_{i=h_{1}}^{h_{n}} x \alpha_{i} \cdot \Delta t \alpha_{i}
$$

Where $S_{\alpha}$ represent the area of temporal series $x \alpha_{i}$ to intervals $\Delta t \alpha_{i}$ of one minute to increase during 24 hours corresponding to the animal $\alpha$. In this study the $S_{\alpha}$ and $x \alpha_{i}$ values can be replaced by the descriptions in the Table 3.1.

The effects of breed on heat partition were analyzed using the PROC MIXED of [23]. The experiment was conducted in a randomized design and the model for the dependent variables included the fixed effect of breed and random effect of sheep. 
The following statistical model was used:

$$
Y=\mu+\alpha(B)+\text { sheep }+\varepsilon
$$

Where:

$Y$ is the dependent variable, $\mu$ is the overall mean, $B$ is the breed (Manchega and Guirra), sheep is random effect and $\varepsilon$ is the random error.

Effects were declared significant at $p<0.05$ and $p$-values between 0.05 and 0.10 were considered as a trend. Student's $t$ test was used for comparison between breeds.

\subsection{Results}

The data on energy intake and outputs of the sheep, recording during the calorimetric measurement, are presented in Table 3.2. No significant difference was observed for the energy balance between breeds.

HE partitioning are shown in Table 3.3. The fasting metabolism in sheep was measured at day 4 after three days of starvation, when respiration quotient has usually fallen to about 0.70 [24]. No differences were observed for FHP between breeds (258 kJ/kg of $\mathrm{BW}^{0.75}$ and day, on average).

The basal metabolism (HeE) was significantly $(\mathrm{p}<0.05)$ higher for Guirra than Manchega breed (270 vs. $247258 \mathrm{~kJ} / \mathrm{kg}$ of BW $\mathrm{BW}^{0.75}$ and day, respectively) and no differences for activity were found ( $258 \mathrm{~kJ} / \mathrm{kg}$ of $\mathrm{B}^{0.75}$ and day).

Table 3.1. Definition of the areas and temporal series used in the numerical integration.

\begin{tabular}{|c|c|c|}
\hline$S_{\alpha}$ & $x \alpha_{i}$ & $h_{n}-h_{1}$ \\
\hline HE (Total Heat Production) & he $\alpha_{i}$ (Heat Production per hour & 24 hours \\
\hline FHP (Fasting Heat Production) & fhp $\alpha_{i}$ (Heat Production per hour) & 24 hours \\
\hline HiE (Heat Increment & hiE $\alpha_{i}$ (Heat Increment per hour) & 24 hours \\
\hline $\mathrm{HdE}_{\mathrm{e}}$ (Heat Increment post ingestion) & $\mathrm{hdE}_{\mathrm{c}} \mathrm{g} \alpha_{i}$ (Heat increment per hour) & Approx.3 hours \\
\hline $\mathrm{HfE}$ (Heat of Fermentation) & $\mathrm{hfE} \alpha_{i}$ (Heat increment per hour) & 24 hours \\
\hline
\end{tabular}


Table 3.2. Dry matter intake $(\mathrm{g} / \mathrm{d})$ and energy balance $\left(\mathrm{kJ} / \mathrm{kg}\right.$ of $\left.B W^{0.75}\right)$ in two sheep breeds.

\begin{tabular}{|c|c|c|c|c|}
\hline & \multicolumn{2}{|c|}{ Breeds } & \multirow[t]{2}{*}{ SEM $^{1}$} & \multirow[t]{2}{*}{ P-value } \\
\hline & Guirras & Manchegas & & \\
\hline $\mathrm{BW}^{2}, \mathrm{~kg}$ & 58.0 & 60.2 & 1.16 & 0.981 \\
\hline $\mathrm{DMl}^{3}, \mathrm{~g} / \mathrm{d}$ & 883.3 & 984.8 & 45.23 & 0.287 \\
\hline \multicolumn{5}{|c|}{ Energy balance, $\mathrm{kJ} / \mathrm{kg}$ of $\mathrm{BW}{ }^{0.75}$} \\
\hline $\mathrm{GEI}^{4}$ & 803 & 854 & 25.3 & 0.34 \\
\hline$E^{5}$ feces & 226 & 260 & 28.8 & 0.56 \\
\hline $\begin{array}{l}\text { E urine } \\
\text { E methane } \\
\text { ME }^{6}\end{array}$ & $\begin{array}{c}41 \\
50 \\
487\end{array}$ & $\begin{array}{c}29 \\
46 \\
518\end{array}$ & $\begin{array}{c}5.5 \\
3.5 \\
13.4\end{array}$ & $\begin{array}{c}0.31 \\
0.66 \\
0.260\end{array}$ \\
\hline $\mathrm{RE}^{7}$ body & 99 & 124 & 14.1 & 0.42 \\
\hline REprotein & 48 & 70 & 7.4 & 0.11 \\
\hline REfat & 52 & 54 & 12.6 & 0.98 \\
\hline ME gain & 132 & 165 & 18.8 & 0.42 \\
\hline $\begin{array}{l}\text { ME maintenance } \\
\mathrm{km}^{8}\end{array}$ & $\begin{array}{l}354 \\
0.77\end{array}$ & $\begin{array}{l}353 \\
0.70\end{array}$ & $\begin{array}{c}8.3 \\
0.021\end{array}$ & $\begin{array}{c}0.95 \\
0.099\end{array}$ \\
\hline
\end{tabular}

${ }^{1} \mathrm{SEM}=$ standard error of the mean; ${ }^{2} \mathrm{BW}=$ body weight; ${ }^{3} \mathrm{DMI}=$ dry matter intake; ${ }^{4} \mathrm{GEI}=$ gross energy intake; ${ }^{5} \mathrm{E}=$ energy; ${ }^{6} \mathrm{ME}=$ metabolizable energy intake; ${ }^{7} \mathrm{RE}=$ retained energy; ${ }^{8} \mathrm{~km}=$ efficiency of ME. 
Table 3.3 HE partitioning $\left(\mathrm{kJ} / \mathrm{kg}\right.$ of $\left.\mathrm{BW}^{0.75}\right)$ and $\mathrm{HE}$ partitioning per MEI (\%) in two sheep breeds.

\begin{tabular}{|c|c|c|c|c|}
\hline \multicolumn{3}{|c|}{ Breeds } & \multirow[t]{2}{*}{ SEM $^{1}$} & \multirow[t]{2}{*}{ P-value } \\
\hline & ras & Manchegas & & \\
\hline \multicolumn{5}{|c|}{ HE partitioning, $\mathrm{kJ} / \mathrm{kg}$ of $\mathrm{BW}^{0.75}$} \\
\hline $\mathrm{HE}^{2}$ & 387 & 394 & 5.5 & 0.56 \\
\hline $\mathrm{HrE}^{3}$ & 33 & 41 & 4.7 & 0.42 \\
\hline $\mathrm{HeE}^{4}$ & 270 & 247 & 4 & 0.02 \\
\hline $\mathrm{Hj}^{5}$ & 23 & 30 & 1.2 & 0.453 \\
\hline $\mathrm{FHP}^{6}$ & 293 & 277 & 2.8 & 0.19 \\
\hline $\mathrm{HdE}^{7}$ & 54 & 71 & 8.8 & 0.39 \\
\hline $\mathrm{HdEe}^{8}$ & 24 & 31 & 5.3 & 0.57 \\
\hline $\mathrm{HdEdm}^{9}$ & 30 & 40 & 5.4 & 0.16 \\
\hline $\mathrm{HiE}^{10}$ & 61 & 77 & 8.7 & 0.4 \\
\hline \multicolumn{5}{|c|}{ HE partitioning per $\mathrm{MEI}^{11}, \%$} \\
\hline REbody/MEI & 20 & 23 & 2.4 & 0.58 \\
\hline REprotein/MEI & 10 & 14 & 1.3 & 0.12 \\
\hline REfat/MEI & 11 & 10 & 2.4 & 0.81 \\
\hline HE/MEI & 80 & 77 & 2.4 & 0.58 \\
\hline $\mathrm{HrE} / \mathrm{MEI}$ & 7 & 8 & 0.8 & 0.57 \\
\hline $\mathrm{HeE} / \mathrm{MEI}$ & 56 & 48 & 1.8 & 0.02 \\
\hline HjE/MEI & 5 & 6 & 0.2 & 0.01 \\
\hline FHP/MEl & 60 & 54 & 1.8 & 0.06 \\
\hline HdE/MEl & 11 & 14 & 2 & 0.49 \\
\hline HdEe/MEI & 5 & 6 & 1.2 & 0.61 \\
\hline HdEdm/MEl & 5 & 8 & 1.2 & 0.21 \\
\hline $\mathrm{HiE} / \mathrm{MEI}$ & 13 & 15 & 2 & 0.52 \\
\hline
\end{tabular}

${ }^{1} \mathrm{SEM}=$ standard error of the mean; ${ }^{2} \mathrm{HE}=$ heat production; ${ }^{3} \mathrm{HrE}=$ heat of product formation; ${ }^{4} \mathrm{HeE}$ = basal metabolism; ${ }^{5} \mathrm{HjE}=$ heat associated with voluntary activity; ${ }^{6} \mathrm{FHP}=$ fasting heat production; ${ }^{7} \mathrm{HdE}=$ heat of digestion; ${ }^{8} \mathrm{HdEe}=$ heat of eating; $9 \mathrm{HdEdm}=$ heat of digestion and metabolism; $10 \mathrm{HiE}=$ heat increment of feeding; ${ }^{11} \mathrm{MEI}=$ metabolizable energy intake; ${ }^{12} \mathrm{RE}$ = retained energy. 
The variation in $\mathrm{HE}$ associated with feeding $(\mathrm{HdE})$ was not significantly different between breeds (62 kJ/kg of $\mathrm{BW}^{0.75}$ and day, on average). No significant differences were observed for the two components related to then; eating-chewing-rumination ( $\mathrm{HdEe})$ and rumination-digestion-metabolism (HdEdm).

The proportional contribution to $\mathrm{HxE}$ due to oxidation of nutrients is shown in Table 3.4. No differences were observed for HxE and OXF and, differences were found in OXCHO and OXP; lower OXCHO $(p<0.05 ; 75$ vs. $129 \mathrm{~kJ} / \mathrm{kg}$ of $\left.\mathrm{BW}^{0.75}\right)$ and higher OXP $\left(\mathrm{p}<0.01 ; 52 \mathrm{vs.} 30 \mathrm{~kJ} / \mathrm{kg}\right.$ of $\left.\mathrm{BW}^{0.75}\right)$ in Guirra than in Manchega breed of sheep.

No significant differences were observed in $\mathrm{N}$ balance, only Guirra breed shown greater $(p<0.05)$ values in urine $N$ compared with Manchega breed: 0.65 vs. $0.35 \mathrm{~g} / \mathrm{kg}$ of $\mathrm{BW}^{0.75}$, respectively (Table 3.5 ).

Table 3.6 shows the ruminal parameters like, $\mathrm{pH}$, ammonia-N and VFA. Higher ammonia- $N$ values $(p<0.05)$ were obtained in Guirra breed compared with Manchega breed (22.8 vs. $17.81 \mathrm{mg} / \mathrm{dL}$, respectively) and numerical lower VFA $(p=0.056)$ in Guirra compared with Manchega (33.49 vs. $37.46 \mathrm{mmol} / \mathrm{L})$.

\subsection{Discussion}

\subsubsection{HE Partition: Activity}

The HjE estimated in our experiment included only the act of standing and lying down. The average value of $\mathrm{HjE}$, in sheep allocated in metabolic cages was $27 \mathrm{~kJ} / \mathrm{kg}$ of $\mathrm{BW}^{0.75}$ and day.

This value represents the $8.5 \%$ of the HeE (expressed on FHP the values is $10 \%$ on average). NRC [25] suggested that energy requirements for activ- ity were $10 \%$ of FHP for stall fed sheep. 
Table 3.4. Energy $\left(\mathrm{kJ} / \mathrm{kg}\right.$ of $\left.\mathrm{BW}^{0.75}\right)$ associated with the oxidation of nutrients and their percentage over HxE in two sheep breeds.

\begin{tabular}{|c|c|c|c|c|}
\hline & \multicolumn{2}{|c|}{ Breeds } & \multirow[t]{2}{*}{ SEM } & \multirow[t]{2}{*}{ P-value } \\
\hline & Guirras & Manchegas & & \\
\hline \multicolumn{5}{|c|}{ Oxidation of nutrients, $\mathrm{MJ} / \mathrm{d}$} \\
\hline $\mathrm{HxE}$ & 8.02 & 8.17 & 0.213 & 0.744 \\
\hline $\mathrm{HfE}$ & 0.14 & 0.13 & 0.013 & 0.650 \\
\hline OXP & 1.1 & 0.54 & 0.116 & 0.006 \\
\hline $\mathrm{OXCHO}$ & 1.54 & 2.33 & 0.399 & 0.353 \\
\hline OXF & 5.31 & 4.25 & 0.489 & 0.307 \\
\hline OXP/HXE, \% & 14 & 7 & 1.41 & 0.002 \\
\hline $\mathrm{OXCHO} / \mathrm{HXE}, \%$ & 19 & 29 & 5.06 & 0.341 \\
\hline OXF/ HXE, \% & 67 & 52 & 6.26 & 0.261 \\
\hline RQnpx & 0.81 & 0.87 & 0.033 & 0.521 \\
\hline HxE/MEI, \% & 76 & 76 & 2.54 & 0.990 \\
\hline HfE/MEl, \% & 1.3 & 1.2 & 0.14 & 0.636 \\
\hline
\end{tabular}

${ }^{1} \mathrm{SEM}=$ standard error of the mean; ${ }^{2} \mathrm{HxE}=$ heat production of oxidation; ${ }^{3} \mathrm{HfE}=$ heat of fermentation; ${ }^{4} \mathrm{OXP}=$ energy associated with the oxidation of protein; ${ }^{5} \mathrm{OXCHO}=$ energy associated with the oxidation of carbohydrate; ${ }^{6} \mathrm{OXF}=$ energy associated with the oxidation of fat; ${ }^{7} \mathrm{RQnpx}=$ non protein respiratory quotient from oxidation of nutrients; ${ }^{8} \mathrm{MEI}=$ metabolizable energy intake. 
Table 3.5. Nitrogen balance $\left(\mathrm{g} / \mathrm{kg}\right.$ of $\left.\mathrm{BW}^{0.75}\right)$ in two sheep breeds

\begin{tabular}{|c|c|c|c|c|}
\hline & \multicolumn{2}{|c|}{ Breeds } & \multirow[t]{2}{*}{ SEM $^{1}$} & \multirow[t]{2}{*}{ P-value } \\
\hline & Guirras & Manchegas & & \\
\hline $\mathrm{N}^{2}$ intake & 1.28 & 1.19 & 0.033 & 0.211 \\
\hline $\mathrm{N}$ feces & 0.3 & 0.35 & 0.031 & 0.429 \\
\hline $\mathrm{N}$ urine & 0.65 & 0.35 & 0.06 & 0.003 \\
\hline $\mathrm{N}$ retained & 0.33 & 0.49 & 0.05 & 0.109 \\
\hline RProtein ${ }^{3}, \mathrm{~g} / \mathrm{d}$ & 43 & 64 & 6.2 & 0.09 \\
\hline RFat $^{4}, \mathrm{~g} / \mathrm{d}$ & 27 & 29 & 8.1 & 0.58 \\
\hline Gain, g/d & 199 & 285 & 23.3 & 0.12 \\
\hline
\end{tabular}

${ }^{1} \mathrm{SEM}=$ standard error of the mean; ${ }^{2} \mathrm{~N}=$ nitrogen; ${ }^{3} \mathrm{R}$ Protein = retained protein; ${ }^{4} \mathrm{RFat}$ $=$ retained fat.

Table 3.6. $\mathrm{pH}$, ammonia $\mathrm{N}$ and volatile fatty acids (VFA) in two sheep breeds.

\begin{tabular}{lcccc}
\hline \multicolumn{2}{c}{ Breeds } & SEM & P-value \\
\hline & Guirras & Manchegas & \\
\hline $\mathrm{pH}$ & 7.3 & 7.22 & 0.172 & 0.652 \\
Ammonia N2, & 22.8 & 17.81 & 3.256 & 0.048 \\
$\mathrm{mg} / \mathrm{dL}$ & & & & \\
Total VFA3, & 33.49 & 37.46 & 3.276 & 0.056 \\
mmol/L & & & & \\
VFA, mmol/L & & & & \\
Acetic & 23.47 & 26.43 & 1.552 & 0.081 \\
Propionic & 6.7 & 5.8 & 0.982 & 0.18 \\
Isobutyric & 0.88 & 0.68 & 0.111 & 0.07 \\
Butyric & 3.55 & 3.15 & 0.573 & 0.55 \\
Isovaleric & 1.28 & 0.93 & 0.142 & 0.24 \\
$\mathrm{~N}$-valeric & 0.51 & 0.32 & 0.024 & 0.48 \\
$\mathrm{~N}$-caproic & 0.07 & 0.09 & 0.003 & 0.35 \\
\hline
\end{tabular}

${ }^{1} \mathrm{SEM}=$ standard error of the mean; ${ }^{2} \mathrm{~N}=$ nitrogen; ${ }^{3} \mathrm{VFA}=$ volatile fatty acids. 
Calorimetric studies have established the following energy cost of various physical activities by ruminants animals [26], and standing compared with lying result in a cost of $10 \mathrm{~kJ} / \mathrm{kg}$ of $\mathrm{BW}^{0.75}$ and day. In our study we assumed that Manchega made more position changes than Guirra breed (63 compared with 48 position changes, respectively). Goats normally prefer standing while feeding and, in our study more activity (standing up) and more DMI was found in Manchega sheep than Guirra breed (985 vs. $883 \mathrm{~g} \mathrm{DMl} / \mathrm{d}$, respectively). However, al- though numerically different, DMI was not significant and considering DMI as percentage of BW, both breeds showed similar DMI $(1.6 \%$ BW). If we express HjE per gram of DMI we obtain 0.55 and $0.66 \mathrm{~kJ} \mathrm{HjE} / \mathrm{g} \mathrm{DMI}$ for Guirra and Manchega breed, respectively. Therefore, the greater value of physical activity in Manchega breed was not due to numerically higher DMI.

\subsubsection{HE Partitioning: Feeding}

The HE has been shown to increase during feeding in sheep [22] like in other mammals. Continuous measurements of respiratory exchange consistently show that HE in sheep increases rapidly by $40 \%-80 \%$ during a course of a meal. This increase persisted even through meals lasting up to 2 hours but declines thereafter rapidly to rates not more than $15 \%-20 \%$ greater than those recorded before a meal (Figure 1).

Most of the studies calculated the cost of eating for a short period of time (15 minutes) and the rate of intake was recorded (g DM per minute or bites per minute). This cost is calculated from the increment in $\mathrm{HE}$ above the average $\mathrm{HE}$ of the pre-feeding period. And it was related to the type and amount of feed consumed and also to the time spent on eating. Our methodology was completely different, with two feeding periods and 24 hours of continuous HE measurement, the measures were based on the greater peak of HE after feeding combined with numerical integration.

Therefore our results are not comparable due that we did not record the rate of intake. We found that the cost of intake during 6 hours (two meals) were $28 \mathrm{~kJ} \mathrm{HdEe} / \mathrm{kg}$ of $\mathrm{BW}^{0.75}$ and day on average, and the cost of digestion and metabolism succeeding 18 hours was $35 \mathrm{~kJ} \mathrm{HdEdm} / \mathrm{kg}$ of $\mathrm{BW}^{0.75}$ and day. The cost of intake with two meals represent the $47 \%$ of the total $\mathrm{HdE}$, while $54 \%$ 
would be the cost of digestion and metabolism of the sheep on the metabolic cages with almost minimal physical activity. The HdEe for two meals account for $6 \%$ of the MEl, while $7 \%$ of the MEl was expended in $\mathrm{HdEdm}$, and no comparable result was found from the litera- ture (Table 3.3). The HfE was more related to the cost of methane produced than total cost of fermentation, and due to this reason $\mathrm{HfE}$ was determined by difference between $\mathrm{HE}$ and $\mathrm{HxE}$, with values of $7 \mathrm{~kJ} / \mathrm{kg}$ of $\mathrm{BW}^{0.75}$, on average (Table 3.4).

In our study, where sheep were fed above maintenance with mixed diet and concentrate pelleted and, non locomotion and thermal stress was considered, the HiE represented $14 \%$ of the MEl. The total energy cost of ingestion and digestion are consistently $40 \%$ to $50 \%$ of $\mathrm{HiE}$ for forages but are less for barley pellets; $24 \%-37 \%$ [27].

\subsubsection{ME for Maintenance}

Feeding level in our trial was estimated as 1.5 times maintenance, hence the sheep was in positive tissue energy balance, and some of the MEl is being directed towards tissue energy gain. The MEm was estimated by difference between MEI and MEr and the value obtained was $354 \mathrm{~kJ} / \mathrm{kg}$ of BW $\mathrm{BW}^{0.75}$ and day on average. The efficiency of use of ME for maintenance was 0.74 on average (slightly higher than NRC [25]), because we have a concomitant energy use for maintenance and gain.

Therefore, next average values were observed (Table 3.3); the MEm represented the $69 \%$ of the total MEI in this study. As sheep were fed above maintenance, the $\mathrm{RE}_{\text {body }}$ account for $23 \%$ of the MEI and, $77 \%$ of the MEI was lost as heat (HE). Within $\mathrm{HE}, 51 \%$ of the MEl drove to basal metabolism ( $\mathrm{HeE}$ ), $5.3 \%$ was lost as physical activity of standing and lying down $(\mathrm{HjE})$, and $13 \%$ was associated with the process of feeding and work of digestion and metabolism.

Reviewing the literature, we found variability in determination or estimation of MEm. Manchega sheep had a value of $383 \mathrm{~kJ} / \mathrm{kg}$ of $\mathrm{BW}^{0.75}$ in the study [28] and day and [29] [30] in Guirra sheep found a value of $352 \mathrm{~kJ} / \mathrm{kg} 0.75$ $\mathrm{BW}$ and day and $391 \mathrm{~kJ} / \mathrm{kg}$ of $\mathrm{BW}^{0.75}$, respectivelyand an efficiency of use of ME for maintenance of $0.64(\mathrm{~km})$. The estimated MEm requirement in Segureña 
sheep by linear regression was $374 \mathrm{~kJ} / \mathrm{kg}$ of $\mathrm{BW}^{0.75}$ and the efficiency of utilisation of ME for maintenance $(\mathrm{km})$ was 0.72 [31]. Nine reports [32] suggest MEm ranging from 305 to $460 \mathrm{~kJ} / \mathrm{kg}$ of $\mathrm{BW}^{0.75}$, and [33] estimated a MEm for Menz sheep of the Ethiopian highlands $422 \mathrm{~kJ} / \mathrm{kg}$ of $\mathrm{BW}^{0.75}$ and day.

The systems [25] and [34] adopted an average value of 321 and 397 $\mathrm{kJ} / \mathrm{kg}$ of $\mathrm{BW}^{0.75}$, respectively due to the fact that FHP vs. feeding trial or, calorimetry studies vs. other methods, give different values. Others [35] consider values of MEm ranging from 325 to $378 \mathrm{~kJ} / \mathrm{kg}$ of $\mathrm{BW}^{0.75}$, and [26] from 286 to $390 \mathrm{~kJ} / \mathrm{kg}$ of $\mathrm{BW}^{0.75} \mathrm{BW}$. Thus, the classical definition of maintenance is not described as the state in which there is neither gain nor loss of nutrient by the body [36], in producing animals never occurs. Consequently, the traditional assumption of the constant MEm that is independent of ME intake may be wrong [37].

\subsubsection{HE Partition: Basal Metabolism}

Higher values for HeE, in Guirra vs. Manchega breed was found (270 vs. $247 \mathrm{~kJ} / \mathrm{kg}$ of $\mathrm{BW}^{0.75}$ ), indicating metabolic differences between the rustic breed (Guirra) than genetically selected breed (Manchega), where basal metabolic rate was greater [38]. However, no differences were found in FHP. We have to keep in mind that Guirra breed reached mature size in this trial, but Manchega sheep were not getting their mature size yet.

Differences in HeE between breeds are difficult to explain. It could be explicated by the feeding level previous to the experiment, that in our study was the same but, in general, this information is not available in literature. In other studies, the FHP value found in Manchega breed [28] was $268 \mathrm{~kJ} / \mathrm{kg}$ of BW $\mathrm{BW}^{0.75}$ and day, akin to our finding, although sheep were fed with a diet based in alfalfa hay and different amount of barley. Similar values were reported in Segureña sheep breed (272 kJ/kg of BW ${ }^{0.75}$ and day) by Aguilera et al. [11], and again the feeding conditions were different; pelleted alfalfa, barley, sunflower meal and olive pulp. However, in the study [29] with Guirra breed with similar BW (57 kg), the FHP was higher (318 kJ/kg of $\mathrm{BW}^{0.75}$ and day) probably due to level of intake prior to fasting was 2.2 times the maintenance, and in our study was 1.5 times maintenance. But, by other hand, [39] found no differences for fasting HE 
between ewes of seven breeds differing in potential of production (296 kJ/kg of $\mathrm{BW}^{0.75}$ and day, on average).

\subsubsection{Oxidation of Nutrients}

The oxidation of fat was $243 \mathrm{~kJ} / \mathrm{kg}$ of $\mathrm{BW}^{0.75}$ on average, and the $\mathrm{OXCHO}$ was lower in Guirra than Manchega (72 vs. $129 \mathrm{~kJ} / \mathrm{kg}$ of $\mathrm{BW}^{0.75}$, respectively). The oxidation of carbohydrates was $33 \%$ of the HxE in Manchega and $19 \%$ in Guirra. While the oxidation of fat accounted for $68 \%$ for Guirra and $59 \%$ in Manchega. Although more oxidation of fat is taking place in Guirra than Manchega, no significant differences were found (Figure 2 shows the oxidation of nutrients over time).

A trial in Guirraewes [30], found differences in oxidation when different type of carbohydrates on diet were used; a diet with $36 \%$ of barley was replaced by the same amount of fibrous by- product (soy hulls and gluten feed blend).

Different pattern of oxidation was found when diet diets is richer in fiber compared with starch based died; the OXF/HxE was $48 \%$ for the fibrous byproduct diet, and the $\mathrm{OXCHO} / \mathrm{HxE}$ was $63 \%$ for barley based diet.

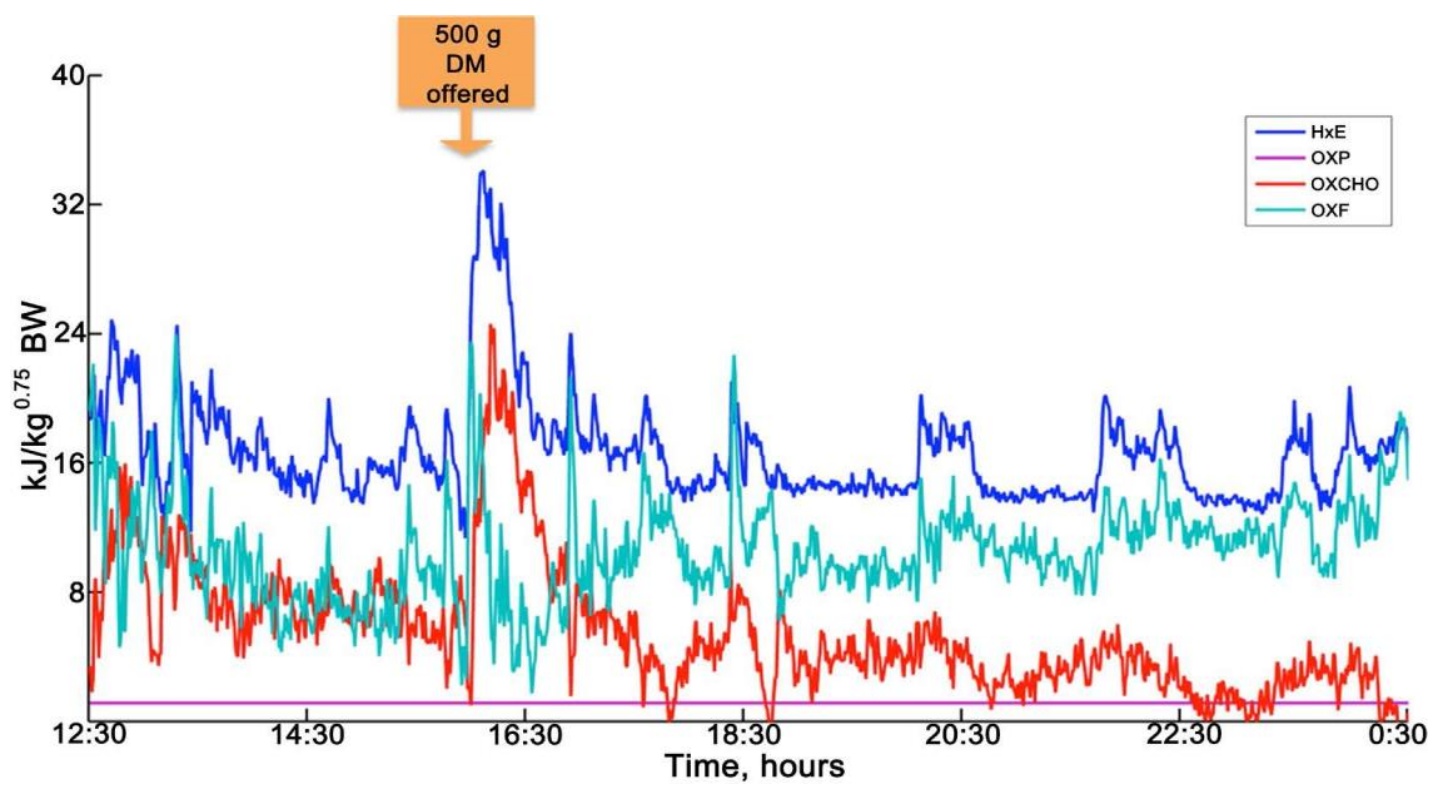

Figure 2. Example of oxidation of nutrients: heat production due to oxidation of nutrients $(\mathrm{HxE})$, oxidation of protein $(\mathrm{OXP})$, oxidation of carbohydrates $(\mathrm{OXCHO})$, and oxidation of fat (OXF). 
However, in this trial the same source of carbohydrate was used in both breeds and, the oxidation of protein in Guirra breed was significantly higher than in Manchega sheep ( $14 \%$ vs. $7 \%$ OXP/HxE, respectively). In the previous studies, mentioned above, no significant differences were observed between diets and the oxidation of protein was $14 \%$ in Guirra breed [30] and $19 \%$ in Manchega breed [28], so more attention should be necessary in this trial for the nitrogen balance (Table 3.5) and rumen parameters (Table 3.6).

\subsubsection{Nitrogen Balance and Rumen Parameters}

The intake of nitrogen was $1.25 \mathrm{~g} / \mathrm{kg}$ of $\mathrm{BW}^{0.75}$ and day on average and, the amount of $\mathrm{N}$ excreted in feces, similar as well $\left(0.33 \mathrm{~g} / \mathrm{kg}\right.$ of $\mathrm{BW}^{0.75}$, on average). However, more $\mathrm{N}$ in urine was found in Guirra than Manchega (0.65 and $0.35 \mathrm{~g} / \mathrm{kg}$ of $\mathrm{BW}^{0.75}$, respectively) and numerical lower retention of protein were found in Guirra (43 vs. $64 \mathrm{~g} / \mathrm{kg}$ of $\mathrm{BW}^{0.75}$, respectively). If we observe the ruminal parameters in Table 3.6, we did not find differences in $\mathrm{pH}$ and profile of VFA, although total amount of VFA was greater in Manchega than Guirra (37.46 vs. $33.49 \mathrm{mmol} / \mathrm{L}$, respectively) and more ammonia $\mathrm{N}$ were found in Guirra compared with Manchega; 22.80 vs. $17.81 \mathrm{mg} / \mathrm{dL}$, respectively. Breeding differences in urine $\mathrm{N}$ losses was due to lack of efficiency for protein use; greater values of ammonia- $\mathrm{N}$ on ruminal liquor. Ruminal ammonia- $\mathrm{N}$ not used for microbial protein synthesis is probably to be excreted in urine [40]. This, associated to the greater OXP and lower OXCHO in Guirra breed, seem indicative of rumen asynchrony between carbohydrates and protein, although we could not identify the cause, more attention should be take to the mature weight.

\subsection{Conclusion}

The present study demonstrated a tentative approach of partitioning HE, combining indirect calorimetry and integral calculus. The MEm was estimated as $354 \mathrm{~kJ} / \mathrm{kg}$ of $\mathrm{BW}^{0.75}$ and day, on average. Differences in basal metabolic rate were found between breeds (270 vs. $247 \mathrm{~kJ} / \mathrm{kg}$ of $\mathrm{BW}^{0.75}$ for Guirra and Manchega, respectively), and the heat increment of feeding was $14 \%$ of the ME intake. Due to the mature weight of the Guirra breed and the feeding level above maintenance, higher $\mathrm{N}$ in urine and rumen ammonia $\mathrm{N}$ was observed. 


\subsection{Acknowledgements}

This study was supported by the INIA Project (ref. RTA2011-00107-C02-02).

\subsection{References}

[1] National Research Council (NRC) (1981) Nutritional Energetics of Domestics Animals and Glossary of Energy Terms. National Academy Science Letters, Washintong DC.

[2] Lachica, M., Prieto, C. and Aguilera, J.F. (1997) The Energy of Walking on the Level and on Negative and Positive Slopes in the Granadina Goat (Capra hircus). British Journal of Nutrition, 77, 73-81. http://dx.doi.org/10.1017/S0007114500002890

[3] Van Klinken, J.B., Van den Berg, S.A.A., Havekes, L.M. and Van Dijk, K.W. (2012) Estimation of Activity Related Energy Expenditure and Resting Metabolic Rate in Freely Moving Mice from Indirect Calorimetry Data.

PLoS ONE, 7, e36162. http://dx.doi.org/10.1371/journal.pone.0036162

[4] European Union (EU) (2003) Protection of Animals Used for Experimental Purposes. Council Directive 86/609/EEC of 24 November 1986, Amended 16.9.2003. European Council, Brussels.

[5] Asociación de Criadores de Raza Guirra (ANCRG) (2014). http://www.anguirra.com

[6] Asociación de Criadores de Raza Manchega (AGRAMA) (2014) http://www.agrama.org

[7] Calsamiglia, S., Bach, A., de Blas, C., Fernández, C. and García-Rebollar, P. (2009) Necesidades nutricionales para rumiantes de leche. Fundación Española para el desarrollo de la Nutrición Animal, Madrid.

[8] Fernández, C., López, M.C. and Lachica, M. (2012) Description and Function of a Mobile Open-Circuit Respirometry System to Measure Gas Exchange in Small Ruminants. Animal Feed Science and Technology, 172, 242-246. http://dx.doi.org/10.1016/i.anifeedsci.2012.01.006

[9] McLean, J.A. and Tobin, G. (1987) Animal and Human Calorimetry. Cambridge University Press, Cambridge.

[10] Brockway, J.M., Boyne, A.W. and Gordon, J.G. (1971) Simultaneous Calibration of Gas Analyzers and Meters. Journal of Applied Physiology, 31, 296-297. 
[11] Aguilera, J.F. and Prieto, C. (1986) Description and Function of an OpenCircuit Respiration Plant for Pigs and Small Ruminants and the Techniques Used to Measure Energy Metabolism. Archives of Animal Nutrition, 11, 1009-1018.

[12] Association of Official Analytical Chemists (2000) Official Methods of Analysis.17th Edition, AOAC, Arlington.

[13] Mertens, D.R. (2002) Gravimetric Determination of Amylase-Treated Neutral Detergent Fibre in Feeds with Refluxing Beakers or Crucibles: Collaborative Study. Journal of AOAC International, 85, 1217-1240.

[14] Batey, I.L. (1982) Starch Analysis Using Thermostable Alpha-Amylases.

Stach/Stärke, 34, 125-128.http://dx.doi.org/10.1002/star.19820340407

[15] Jouany, J.P. (1982) Volatile Fatty Acid and Alcohol Determination in

Digestive Contents, Silage Juices, Bacterial Cultures and Anaerobic Fermentor Contents. Sciences des Aliments, 2, 131-144.

[16] Brouwer, E. (1965) Report of Sub-Committee on Constants and Factors. In: Blaxter, K.L., Ed., Proceedings of the 3rd Symposium on Energy Metabolism, Academic Press, London, 441-443.

[17] Brouwer, E. (1958) On Simple Formulae for Calculating the Heat Expenditure and the Quantities of Carbohydrate and Fat Metabolized in Ruminants, from Data on Gaseous Exchange and Urine N. In: Proceedings of the 1st Symposium on Energy Metabolism, Academic Press, London, 182-194.

[18] Chwalibog, A., Tauson, A.H. and Thorbek, G. (1997) Quantitative Oxidation of Nutrients in Growing Calves. Zeitschrift für ernährungswissenschaft, 36, 313-316. http://dx.doi.org/10.1007/BF01617806.

[19] Fahey, G.C. and Berger, L.L. (1988) Carbohydrate Nutrition of Ruminants. In: Church, D.C., Ed., The Ruminant Ani- mal, Digestive Physiology and Nutrition, Prentice Hall, Engleood Cliff, 269-297.

[20] Agricultural and Food Research Council (AFRC) (1993) Agricultural and Food Research Council. Energy and Protein Requirements of Ruminants. CAB International, Wallingford, UK.

[21] Baldwin, R.L. (1995) Modeling Ruminant Digestion and Metabolism. Chapman and Hall, London, 578 p. 
[22] Osuji, P.O., Gordon, J.G. and Webster, A.J.F. (1975) Energy Exchanges Associated with Eating and Rumination of Sheep Given Grass Diets of Different Physical Form. British Journal of Nutrition, 34, 59-71.

[23] SAS, Statistical Analysis System (2001) User's Guide, Version 8.02. Statistical Analysis System Institute Inc., Cary.

[24] Blaxter, K.L. (1967) Techniques in Energy Metabolism Studies and Their Limitations. Proceedings of the Nutrition Society, 26, 86-96. http://dx.doi.org/10.1079/PNS19670016.

[25] National Research Council, NRC (2007) Nutrient Requirements of Small Ruminants: Sheep, Goats, Cervids, and New World Camelids. The National Academies Press, Washington DC.

[26] Commonwealth Scientific and Industrial Research Organisation (2007) Nutrients Requirements of Domesticated Ru- minants. CSIRO, Collingwood.

[27] Webster, A.J.F. (1983) Chapter 6: Energetic of Maintenance and Growth. In: Girardier, L. and Stock, M., Eds., Mam- malian Thermogenesis, Chapman and Hall, London, 178-207. http://dx.doi.org/10.1007/97894-011-6032-2 6

[28] Fernández, C., López, M.C. and Lachica, M. (2012) Heat Production Determined by the RQ and $C N$ Methods, Fasting Heat Production and Effect of the Energy Intake on Substrates Oxidation of Indigenous Manchega Sheep. Animal Feed Science and Technology, 178, 115119. http://dx.doi.org/10.1016/j.anifeedsci.2012.09.007

[29] López, M.C. and Fernández, C. (2013) Changes in Heat Production by Sheep of Guirra Breed after Increase in Quan- tity of Barley Grain on the Diet. Small Ruminant Research, 109, 113-118. http://dx.doi.org/10.1016/..smallrumres.2012.07.008

[30] López, M.C. and Fernández, C. (2014) Energy Partitioning and Substrate Oxidation by Guirra Ewes Fed Soy Hulls and Corn Gluten Feed Blend as a Replacement for Barley Grain. Animal Feed Science and Technology, 189,11-18.

http://dx.doi.org/10.1016/j.anifeedsci.2013.12.005 
[31] Aguilera, J.F., Molina, E., Prieto, C. and Boza, J. (1986) Determination of Energy Requirements for Maintenance in Sheep of Segureña Breed. Archivos de Zootécnia, 35, 89-96.

[32] Kearl, L.C. (1982) Nutrient Requirements of Ruminants in Developing Countries. International Feedstuffs Institute, Utah State University, Logan.

[33] Nsahlai, I.V., Osuji, P.O. and Umunna, N.N. (1997) Digestible Organic Matter Requirements of Ethiopian Menz Sheep: Model and Application. Journal of Applied Animal Research, 11, 83-100. http://dx.doi.org/10.1080/09712119.1997.9706164

[34] Institut National de la Recherche Agronomique, INRA (2007) Alimentation des bovins, ovinsetcaprins. Besoins des animaux. Valeurs des aliments. Tables Inra 2007. Editions Quae, Versailles.

[35] Agricultural and Food Research Council, AFRC (1998) Energy, in Nutrition of Sheep. CAB International, Wallingford, UK, 41-45.

[36] Blaxter, K.L. (1972) Fasting Metabolism and the Energy Required by Animals for Maintenance. In: Festsdrifttil Knut Breirem, Mariendals Boktryk-keri, Gjovik, 19.

[37] Labussière, E., Dubois, S., Van Milgen, J., Bertrand, G. and Noblet, J. (2008) Fasting Heat Production and Energy Cost of Standing Activity in Veal Calves. British Journal of Nutrition, 100, 1315-1324. http://dx.doi.org/10.1017/S0007114508980648

[38] Taylor, S.C.S. (1985) Use of Genetic Size-Scaling in Evaluation of Animal Growth. Journal of Animal Science, 61, 118-143.

[39] Olthoff, J.C., Dickerson, G.E. and Nienaber, J.A. (1989) Energy Utilization in Mature Ewes from Seven Breeds with Diverse Production Potential. Journal of Animal Science, 67, 2550-2564.

[40] Hoover, W.H. and Stokes, S.R. (1991) Balancing Carbohydrates and Proteins for Optimum Rumen Microbial Yield. Journal Dairy Science, 74, 3630-3644. http://dx.doi.org/10.3168/jds.S0022-0302(91)78553-6 
GENERAL DISCUSSION 

Bioenergetics study the flow and transformation of energy in and between living organisms and between living organism and their environment. The results in the present Thesis related to energetic of animal nutrition were obtained by means of respiration and balance experiments. The respiration unit worked according to the indirect calorimetry principle with open air circulation to measure the gas exchange. The design and function of the respiration unit was described by Fernández et al. (2012; 2015). The calculation of the heat production and the energy balances were performed with a set of factors and constants proposed by Brouwer (1965).

The three experiments of this Thesis calculate the ME in different species (goats and sheep) and under different physiological stages (lactating goat and dry and no pregnant sheep). Due that ME is used partly for maintenance and partly for production, effort was done to separate ME in different components. Information about the maintenance requirement is necessary in order to evaluate the amount of $\mathrm{ME}$ available for production and to estimate the efficiency of energy conversion into products. The classical definition of maintenance by Blaxter 1989 "state in which there is neither gain nor loss of nutrients by the body" means that the ME requirements for maintenance has to be defined as the amount of energy required to balance anabolism and catabolism, giving an energy retention around zero. This definition is acceptable for adult and nonproductive animals, however, in producing animal's energetic equilibrium never occurs, and such defined ME for maintenance has to be regarded as a more theoretical figure.

The experiment 1 and 2 were conducted in lactating goats and the main objective was to evaluate the efficiency of utilization of the different mixed diets. These two experiments were not designed to determined ME of maintenance under different feeding levels, so the MEm was taken from the literature. In the experiment 1 we assumed the value proposed by Aguilera et al. (1990) and it was $401 \mathrm{~kJ} / \mathrm{kg}$ of $\mathrm{BW}^{0.75}$. After correct milk energy to energy balance zero the efficiency of use of ME for milk production was 0.72 , a little bit higher than literature values as we mentioned on experiment 1. Animals in lactation has higher metabolic activity of visceral organs than maintenance animals, so in the second trial we decided to assume a greater value $497 \mathrm{~kJ} / \mathrm{kg}$ of $\mathrm{BW}^{0.75}$ 
proposed by NRC (2007) and the average value obtained for kl was 0.62 . Regards to the third trial, sheep were not in lactation. Sheep were nonproductive animals feeding above maintenance. Under these conditions, MEm was estimated and a value of $354 \mathrm{~kJ} / \mathrm{kg}$ of $\mathrm{BW}^{0.75}$ was obtained.

Experiments in this work point to different applications for calorimetry and will be discussed independently.

\section{Experiment 1}

Most of the concentrates for dairy ruminants are based on cereals. Cereal grains are the most common sources of readily available energy for livestock and comprise up to $60 \%$ of the total diet for high-yielding dairy ruminants. Given the ability of ruminal microorganism to degrade fiber, some byproducts of other agricultural and industrial process are used to replace cereal (starch is replaced with highly digestible fibers as a main source of energy). One such byproduct is rice bran (FAOSTAT, 2014).

In this experiment the main differences between diets is the source of carbohydrate; oat grain is the cereal with highest content of fiber and the main characteristic of rice bran is the protein and fat content. In order to balance the diet additional fat was incorporate in both diets, so rice bran diet (RB) had twice times more fat than oat grain diet (O). This situation dissembled the potential effect of rice bran in the diet. Significant differences in DMI were observed, not in digestibility coefficients. The RB diet reducts $\mathrm{DMI}$ at $12 \%$ without altering milk production, due to the diet RB had almost $12 \%$ of fat and, as Palmquist and Jenkins (1980) mentioned, diet fat in the rumen destroy cellulolytic bacteria and depress the DMI.

Diet that incorporate RB shown better nutrient balance toward milk (33 kJ $\mathrm{E}_{\text {milk }} / \mathrm{kg}$ of $\mathrm{BW}^{0.75}$ more in $\mathrm{RB}$ than $\mathrm{O}$ ), worse ruminal parameters and no effect was observed for ME intake (1254 kJ/ kg of $\mathrm{BW}^{0.75}$, on average). Regards to milk performance, similar milk yield ( $2.2 \mathrm{~kg} / \mathrm{d}$ on average) were found and, milk chemical composition was different for fat ( 7 vs. $5 \%$ for RB and $O$, respectively), probably link to the higher content of fat in rice bran and the by-pass fat added to RB treatment. 
The $\mathrm{C} 11: 0$ and $\mathrm{C} 15: 0$ milk fatty acids are potential biomarkers of rumen function since they are found in rumen bacterial lipids and might be partially synthesized endogenously from rumen substrates in the mammary gland (Vlaeminck et al., 2006, Fievez et al., 2012 and Vlaeminck et al., 2015). The differences found between treatments (lower contents of those fatty acids in the milk of RB goats) suggest a negative impact of $\mathrm{RB}$ oil on rumen bacterial metabolism, both de novo synthesis of bacterial lipids and the fermentative activity. Goats fed RB diet produced fewer $\mathrm{CH}_{4}$ emissions $(23.2 \mathrm{~g} / \mathrm{d})$ than $\mathrm{O}$ diet $(30.1 \mathrm{~g} / \mathrm{d})$. Increasing the lipid content of the diet is acknowledge as a $\mathrm{CH}_{4}$ mitigation strategy due to reduction of methanogenesis and the biohydrogenation of unsaturated fatty acids (alternative sink of $\mathrm{H}_{2}$ ). Also, $\mathrm{CH}_{4}$ output was positively correlated to milk C6:0 to C16:0 (Fievez et al. 2012), which result mainly from mammary de novo fatty acids synthesis, based primarily on the use of acetate produced in the rumen during fiber digestion and being, these milk fatty acids contents, lower in RB diet.

\section{Experiment 2}

Other practical situation is the forage we use to fed lactating goats. Maralfalfa is getting popularity in our country because fix nitrogen from the soil and because is having a good adaptation to template climates. An experiment was done by using two types of diets, in this case, the same foodstuff and two kinds of alfalfa forage $(A)$ and Maralfalfa $(M)$.

Diet that incorporate alfalfa as forage shown better nutrient balance towards milk ( $35 \mathrm{~kJ} \mathrm{E}_{\text {milk }} / \mathrm{kg}$ of $\mathrm{BW}^{0.75}$ more in $\mathrm{A}$ than $\mathrm{M}$ ), ruminal parameters and milk yield (1.8 vs. $1.7 \mathrm{~kg} / \mathrm{d}$ for $\mathrm{A}$ and $\mathrm{M}$, respectively) although no effect was observed for ME intake $\left(1088 \mathrm{~kJ} / \mathrm{kg}\right.$ of $\left.\mathrm{BW}^{0.75}\right)$ and milk chemical composition.

We mentioned that $A$ diet shown greater milk production and seems that it is influenced by microbial $\mathrm{N}$ synthesis because of the significant contribution of microbial protein to the goat's protein requirements (Bjerre-Harpøth et al., 2012). Milk uric acid is a potential biomarker of rumen $N$ flow and feed efficiency; milk uric acid increase as microbial nitrogen flow increases. 
Odd and branched chain fatty acid in milk are predominantly of microbial origin. The differences found between treatments (higher contents of C15:0 and $\mathrm{C} 17: 0$ in the milk of $\mathrm{M}$ goats) suggest an amylolytic rumen bacterial metabolism.

Milk concentration of $\mathrm{C} 15: 0$ and the sum of $\mathrm{C} 17: 0$ and cis-9 $\mathrm{C} 17: 1$ are positively related to propionate concentration in the rumen as these are synthesized from propionate de novo (Castro-Montoya et al. 2011). Propionate production is negatively related to $\mathrm{CH}_{4}$ production, suggesting a negative relationship between milk odd chain fatty acids concentration and $\mathrm{CH}_{4}$ yield (Van Lingen et al., 2014). The $\mathrm{CH}_{4}$ emission was lower in the diet with greater concentration of rumen propionic acid (28.5 vs. $25.9 \mathrm{~g} / \mathrm{d}$ A and $\mathrm{M}$, respectively).

Regarding to these two experiments, most transition dairy goats are confronted with negative energy balance in early lactation. Besides, production diseases and reproductive issues are serious problems on most dairy farms and it has been hypothesized that physiological imbalance in individual goats is a major cause for certain diseases during lactation, as also happen in cows. Several indicators in milk (odd chain fatty acids and metabolites) are being used on farm to identify cows with metabolic diseases (Bjerre-Harpøth et al., 2012, Fievez et al. 2012). No much information is available of this topic in dairy goats. During the experiment 1 and 2 we found that the energy balance and oxidation of nutrients are related with rumen parameters, milk yield and milk metabolites. The nutritive unbalance found when some ingredients were replaced with others was detected in the energy balance and milk metabolites or odd chain fatty acid. Therefore, biomarkers for energy status in combination with indirect calorimetry might be used with the objective to identify possible biomarkers of fat mobilization or retention in dairy goats.

\section{Experiment 3}

Experiment 3 brings up the challenge of the heat production partitioning. Measurement of heat production by indirect calorimetry offers the chance to evaluate variations among animals according to their genotype, phenotype, or environment conditions. Energy can be divided even more in that it is associated with basal metabolism, voluntary activity, product formation, 
digestion and absorption, thermal regulation, fermentation heat, and residual formation and excretion.

The partition of heat production is the most difficult and controversial aspect of all feeding systems This trial have tried to partition the heat production in the thermal increase associated to intake which was measured in two sheep breeds by the indirect calorimetry method and mathematic calculations.

In our study we assumed that the fasting heat production (FHP) is basal metabolism plus physical activity, with a total average value of $285 \mathrm{~kJ} / \mathrm{kg}$ of $\mathrm{BW}^{0.75}$ and day. The HP by activity, which includes standing up and lying down, was $27 \mathrm{~kJ} / \mathrm{kg}$ of $\mathrm{BW}^{0.75}$ and day, representing $8.5 \%$ of the basal metabolism, which would represent $10 \%$ of the FHP.

Total HP was $387 \mathrm{~kJ} / \mathrm{kg}^{0.75} / \mathrm{day}$ for Guirras and 394 for Manchegas. The cost of ingestion for two meals represent $7 \%$ of the $\mathrm{MEI}$.

Van Klinken et al. (2012) estimate the activity related to energy expenditure and resting metabolic rate in mice from indirect calorimetry by means of Kalman filtering and penalized Spline regression. Look for mathematical methods than combine indirect calorimetry and animal activities could be a great help although these techniques have not been evaluated in this Thesis.

Other methods, like electronic devices (heart rate, podometers, electronic scales, GPS collard, ECGs, etc.), in order to improve the energy decomposition and add more precision we may use electronic devices which will help to accurately measure; there are some works, for example Zehner et al. (2012) developed a "health monitoring system" for cows or Werner et al 2014 in horses, that automatically measures rumia (times of swallowing and chewing), ingestion of foodstuffs (times of chewing), water and locomotion (podometers), these methods combine electronic signal with mathematical algorithms.

More effort should be made combining electronic devices and mathematical methods in order to quantify the different physiological situations that are included under the heat production definition. 

CONCLUSIONS 

1. Indirect calorimetry is a accurately technique to measure heat production and $\mathrm{CH}_{4}$, can be used at a practical level or under field conditions if the device is mobile such as Head Hood used in this Thesis.

2. The Experiment 1 replaced oat grain with rice bran and a reduction of dry matter intake by $12 \%$ was found due probably to the high content of fat in rice bran (14\%).

3. No differences were found in milk yield $(2.2 \mathrm{~kg} / \mathrm{d}$, on average) and the $\mathrm{kl}$ was 0.72 for the two diets.

4. Enteric $\mathrm{CH}_{4}$ emissions were reduced $6.9 \mathrm{~g} / \mathrm{d}$ by the diet that incorporate rice bran, and the milk fat content was higher in rice bran than oat diet ( 7 vs. $5 \%$, respectively).

5. It was difficult to evaluate the effect of replacement of oat grain with rice bran because both diets incorporated by-pass fat.

6. Experiment 2 shown better performance (rumen function, milk yield and milk biomarker as uric acid) in mixed diets using alfalfa as forage than maralfalfa. So, the kl was 0.64 for diet alfalfa and 0.57 for diet maralfalfa.

7. In Experiment 2 more $\mathrm{CH}_{4}$ was obtained in alfalfa than maralfalfa; 29 vs. 26 $\mathrm{g} / \mathrm{d}$, although these differences disappear when methane is expressed on dry matter intake basis.

8. In the Experiment 3 the MEm for the Guirra and Manchega breeds was 354 $\mathrm{kJ} / \mathrm{kg}$ of $\mathrm{BW}^{0.75}$ on average. 
9. The calculation of heat increment of feeding was $69 \mathrm{~kJ} / \mathrm{kg}$ of $\mathrm{BW}^{0.75}$ and day on average, and the heat associated with voluntary activity was $27 \mathrm{~kJ} / \mathrm{kg}$ of $\mathrm{BW}^{0.75}$ and day on average

10. The basal metabolic rate was different between breeds; $270 \mathrm{~kJ} / \mathrm{kg}$ of $\mathrm{BW}^{0.75}$ and day for Guirra sheep, and $247 \mathrm{~kJ} / \mathrm{kg}$ of $\mathrm{BW}^{0.75}$ and day for Manchega sheep. 
REFERENCES 

Aguilera, J. F., Prieto, C., Fonollá, J., 1990. Protein and energy metabolism of lactating Granadina goats. Br. J. Nutr. 63:165-175.

Bjerre-HarpØth, V., Friggens, N.C., Thorup, V.M., Larsen, T., Damgaard, B.M., Ingvartsen, K.L., Moyes, K.M., 2012. Metabolic and production profiles of dairy cows in response to decreased nutrient density to increase physiological imbalance at different stages of lactation. J. Dairy Sci. 95:2362-2380.

Blaxter, K.L., 1989. Energy Metabolism in Animals and Man. Cambridge, UK Cambridge Univ. Press.

Brouwer, E., 1965. Report of sub-committee on constants and factors. In: Blaxter, K.L. (Ed.), Proceedings of the Third EAAP Symposium on Energy Metabolism. Publication No. 11. Academic Press, London, pp. 441-443.

Castro-Montoya, J., Bhagwat, A.M., Peiren, N., De Campeneere, S., De Baets, B., Fievez, V., 2011. Relationships between odd- and branched-chain fatty acid profiles in milk and calculated enteric methane proportion for lactating dairy cattle. Anim. Feed Sci. Technol. 166:596-602.

FAOSTAT. 2014. FAO. Statistical Database, Food and Agricultural Organization of the United Nations, Rome, Italy. Accessed. Dec 15, 2014. http://faostat.fao.org

Fernandez, C., Lopez, M.C., Lachica, M., 2012. Description and function of a mobile open-circuit respirometry system to measure gas exchange in small ruminants. Anim. Feed Sci. Technol. 172:242-246.

Fernández, C., López, M.C., Lachica, M., 2015. Low cost open-circuit hood system for measuring gas exchange in small ruminants: from manual to automatic recording. J. Agri. Sci. 153:1302-1309.

Fievez, V., Colman, E., Castro-Montolla, J.M., Stefanov, I., Vlaeminck, B., 2012. Milk odd- and branched-chain fatty acids as biomarkers of rumen functionAn update. Anim. Feed Sci. Technol. 172:51-65.

National Research Council (NRC), 2007. Nutrient Requirements of Small Ruminants. Sheep, Goats, Cervids and New World Camelids. National Academy Press, Washington, D.C.

Palmquist, D.L., Jenkins, T.C., 1980. Fat in lactation rations: Review. J. Dairy Sci. 63:1-14. 
Van Klinken, J.B., Van den Berg, S.A.A., Havekes, L.M., Van Dijk, K.W., 2012. Estimation of Activity Related Energy Expenditure and Resting Metabolic Rate in Freely Moving Mice from Indirect Calorimetry Data. PLoS ONE, 7, e36162. http://dx.doi.org/10.1371/journal.pone.0036162

Van Lingen, H.J., Crompton, L.A., Hendriks, W.H., Reynolds, C.K., Dijkstra, J., 2014. Meta-analysis of relationships between enteric methane yield and milk fatty acid profile in dairy cattle. J Dairy Sci. 97:7115-7132.

Vlaeminck, B., Fievez, V., Cabrita, A.R.J., Fonseca, A.J.M., Dewhurst. R.J., 2006. Factors affecting odd-and branched-chain fatty acids in milk: A review. Anim. Feed Sci. Technol. 131:389-417.

Vlaeminck, B., Gervais, R., Rahman, M.M., Gadeyne, F., Gorniak, M., Doreau, M., Fievez, V., 2015. Postruminal synthesis modifies the odd- and branched-chain fatty acid profile from the duodenum to milk. J. Dairy Sci. 98:4829-4840.

Werner, J., Zehner, N., Umstätter, C., Nydegger, F., Hoch, M., Wyss, C., Schick, M., In: $7^{\text {th }}$ Conference of the European Workshop on Equine Nutrition. 29. September - 02.October, Publ. EWEN, Leipzig. 2014, 1-2.

Zehner, N., Niederhauser, J. J., Nydegger, F., Grothmann, A., Keller, M., Hoch, M., Haeussermann A., Schick, M., 2012. Validation of a new health monitoring system (RumiWatch) for combined automatic measurement of rumination, feed intake, water intake and locomotion in dairy cows. In: Proceedings of International Conference of Agricultural Engineering CIGRAgEng, 2012:Agriculture and Engineering for a Healthier Life, Valencia, Spain, 8-12 July 20122012 pp. C-0438. 
